\title{
EVALUATION OF MICROALGAE FOR SECONDARY AND TERTIARY WASTEWATER TREATMENT
}

\author{
by \\ Zainab Kadhim Abdulsada \\ B. Eng. Environmental Engineering
}

A thesis submitted to the Faculty of Graduate and Postdoctoral Affairs in partial fulfillment of the requirements for the degree of

Master in Applied Science

in

Environmental Engineering

Department of Civil and Environmental Engineering

Carleton University

Ottawa-Carleton Institute for Environmental Engineering

Ottawa, Ontario

August 2014

(C) 2014, Zainab Kadhim Abdulsada 


\begin{abstract}
In this study, use of microalgae for secondary and tertiary wastewater treatment was evaluated. First phase of the study investigated the ability of microalgae to remove nutrients, organic carbon and indicator bacteria from secondary effluents and centrate. For secondary wastewater and centrate, the reductions in soluble concentrations of total nitrogen, phosphorus, and COD were 27, 51.7, 29.5\% and 49.4, 78.6. 32.8\%, respectively. Total coliform reduction was greater than $99.5 \%$. The second phase investigated the use of microalgae in combination with activated sludge system. Soluble COD removal improved from $1.5 \%$ for sample A (activated sludge) to 65.6 and $77.8 \%$ for samples B (activated sludge and microalgae) and C (microalgae). Ammonia was removed by $99.9 \%$ for $\mathrm{B}$ and $\mathrm{C}$, while the removal was $46.4 \%$ for $\mathrm{A}$. Total dissolved phosphorus was removed by 81.3 and $73.2 \%$ for $\mathrm{B}$ and $\mathrm{C}$, but there was no reduction in dissolved phosphorus for A.
\end{abstract}




\section{Acknowledgements}

My first and deepest gratitude goes to Allah for uncountable blessings that are (and will be) given to me in my life.

I would like to give special thanks to my supervisor Professor Banu Ormeci for her continuous encouragement and scientific support during my study. Also, deep appreciation goes to my examination committee for their time and efforts in reading, reviewing and providing valuable suggestion on this thesis.

Also, I would like to thank the professors whose courses were very informative and enjoyable. Thanks Prof. Delatolla, Prof. Rayhani, Prof. Fall, Prof. Seidou and others. Through you and prof. Ormeci, I have gained a strong scientific background that will contribute to my success in my scientific journey.

I, also, give special thanks to Dr. Marie Tudoret for her kind help and continuous support in the lab during my experimental work. Many thanks go to kind, helpful and lovely people who helped me directly or indirectly during this time of my life.

I am very thankful to my parents for their continous praying that keeps me safe and happy. Finally, special thanks to my husband and lovely kids for their exceptional love, support and patience throughout this process. 


\section{Table of contents}

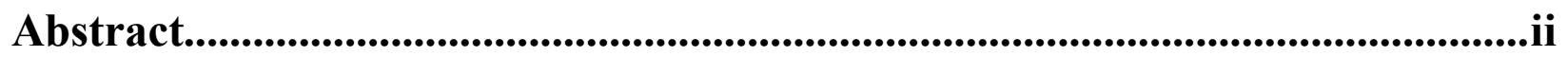

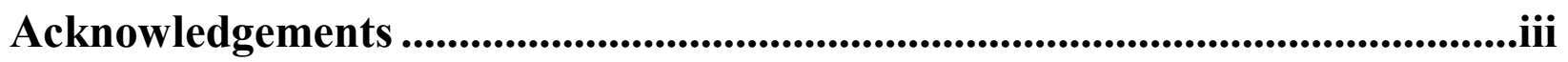

Table of contents .....................................................................................................

List of tables .................................................................................................................viii

List of figures..........................................................................................................................ix

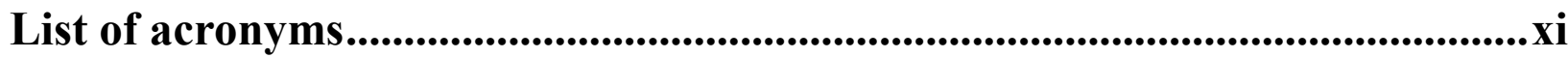

List of appendixes ......................................................................................................................xii

Chapter 1 Introduction ................................................................................................................. 1

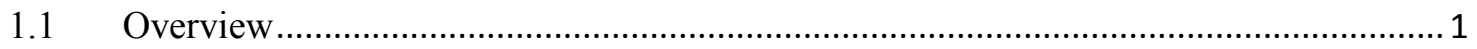

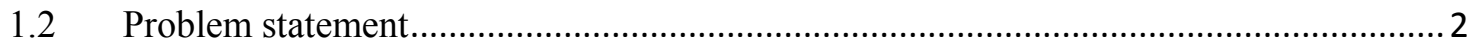

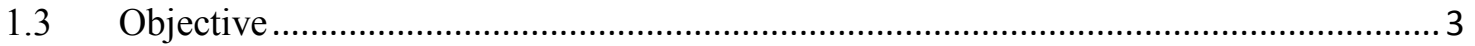

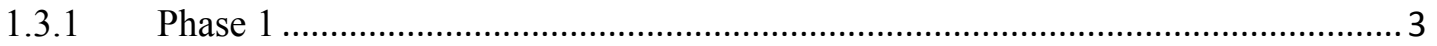

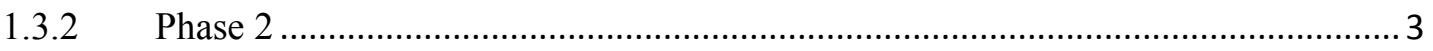

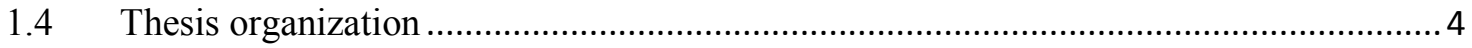

Chapter 2 Literature review and background.......................................................5

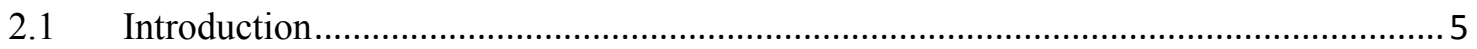

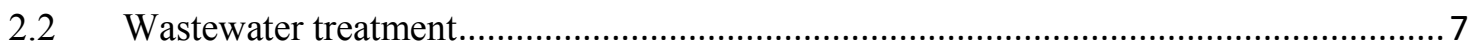

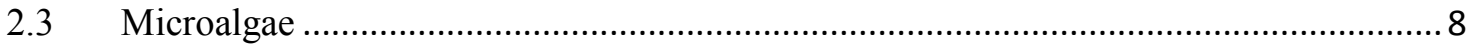

$2.4 \quad$ Role of microalgae in wastewater treatment ........................................................... 10

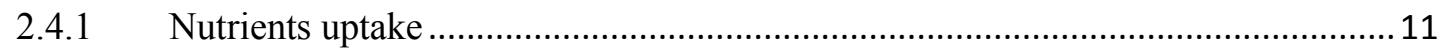

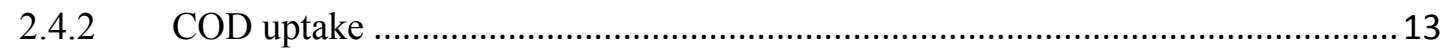

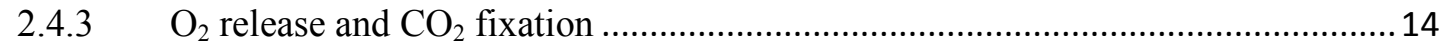

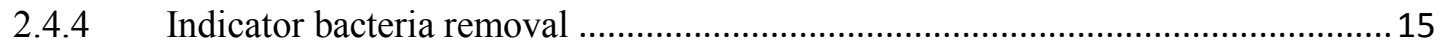




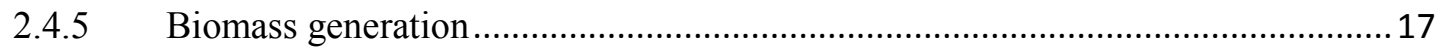

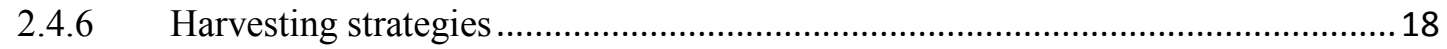

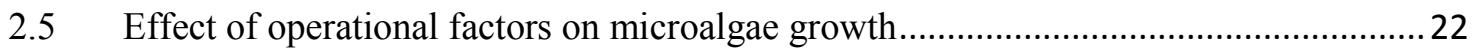

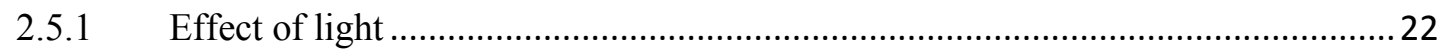

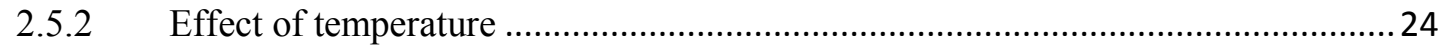

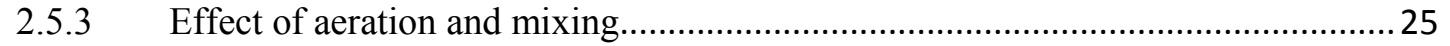

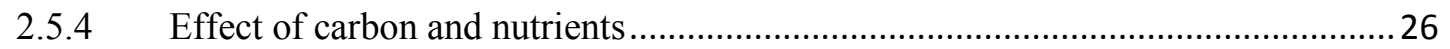

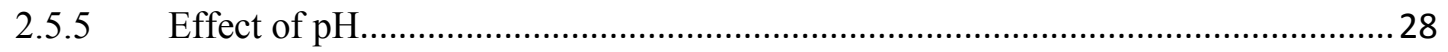

2.5.6 Effect of grazer organisms and viruses .......................................................... 30

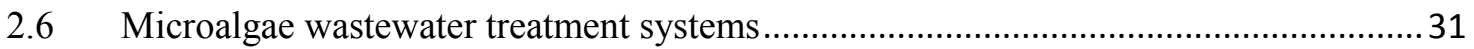

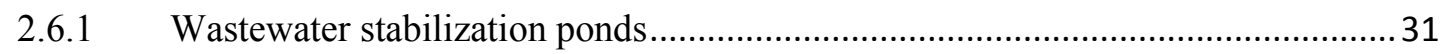

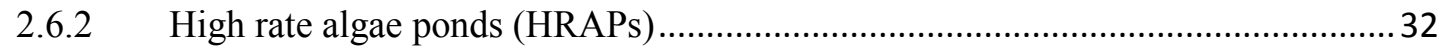

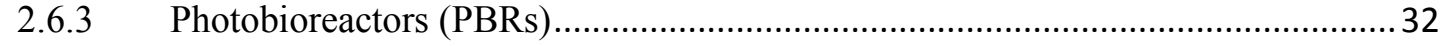

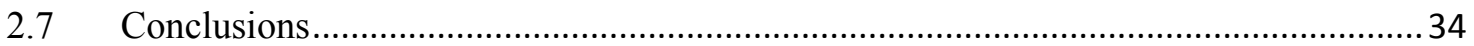

\section{Chapter 3 Materials and methods...............................................................................36}

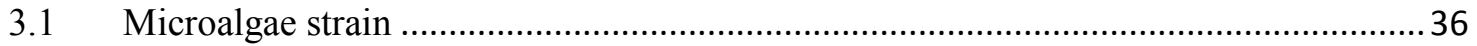

3.2 Microalgae cultivation, monitoring and harvesting ................................................. 36

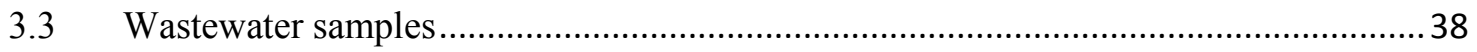

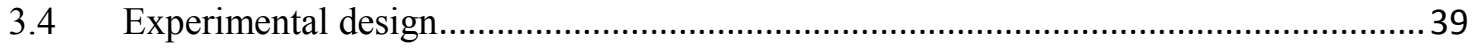

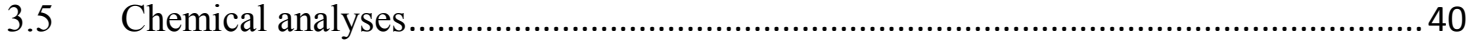

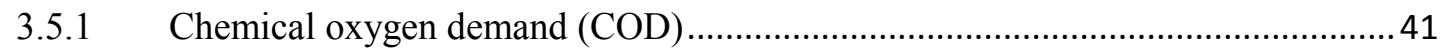

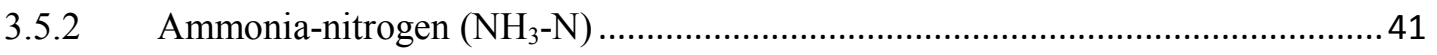

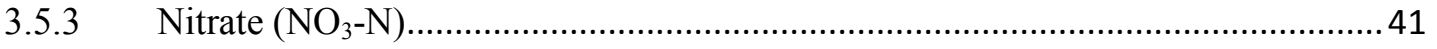

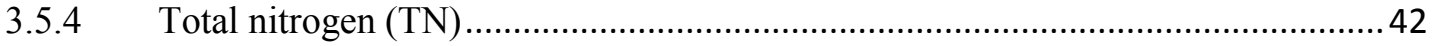

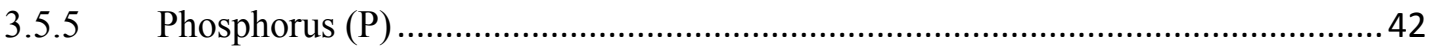

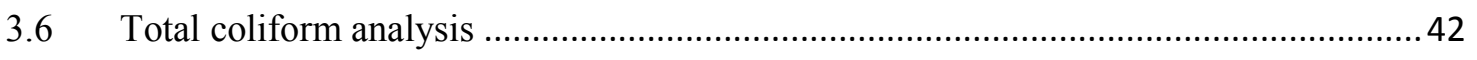

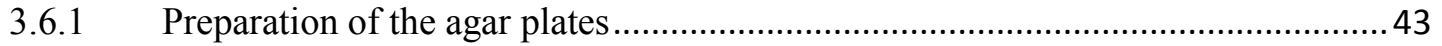

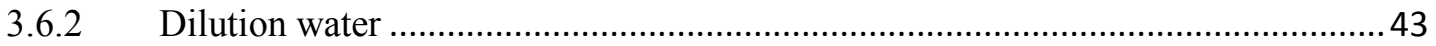

3.6.3 Membrane filtration (MF) procedure ............................................................ 43

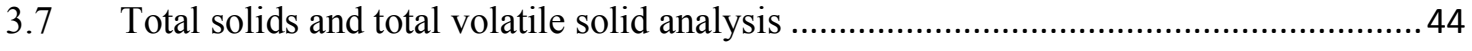

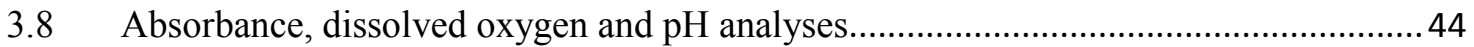




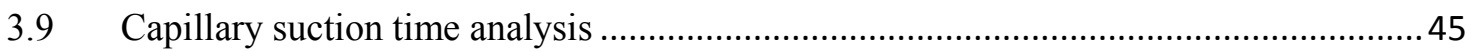

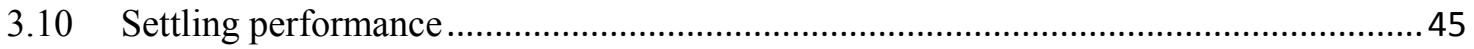

\section{Chapter 4 Phase 1: Using microalgae for treatment of secondary}

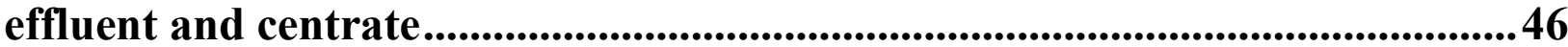

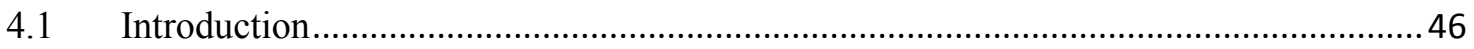

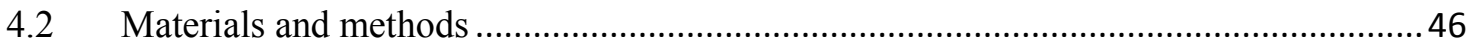

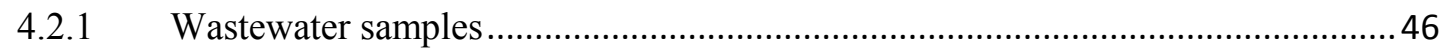

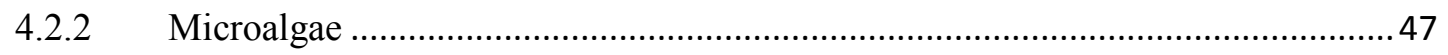

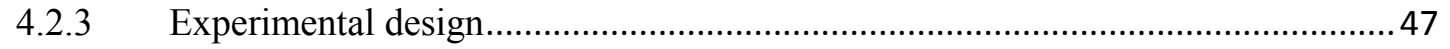

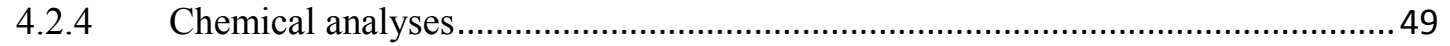

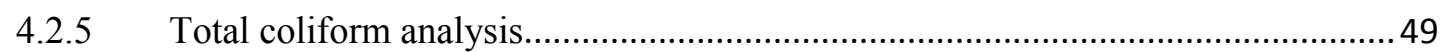

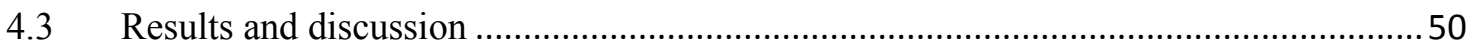

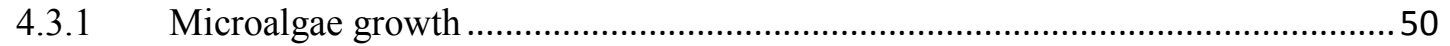

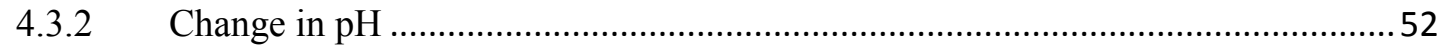

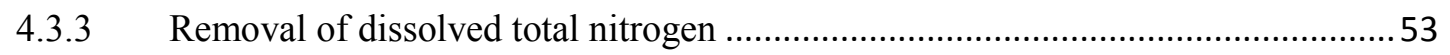

4.3.4 Removal of dissolved phosphorus ................................................................... 55

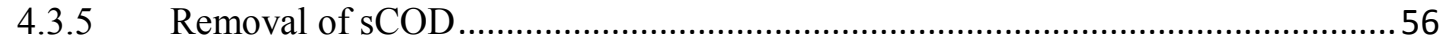

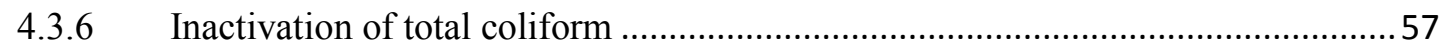

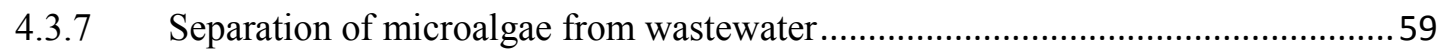

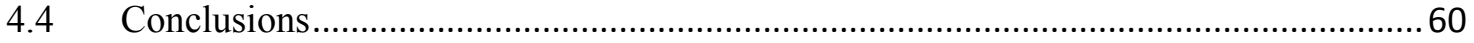

\section{Chapter 5 Phase 2: Microalgae in combination with activated sludge}

process.

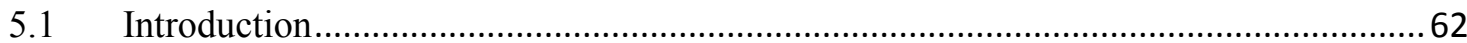

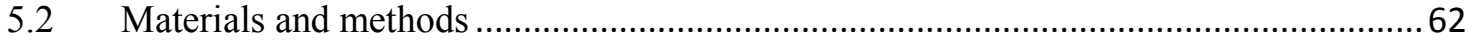

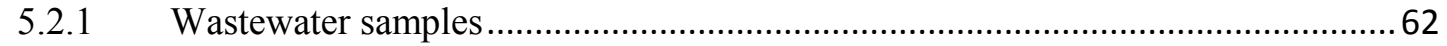

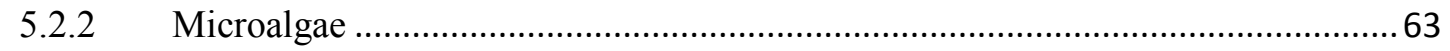

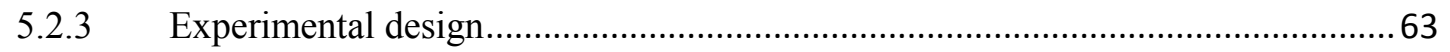

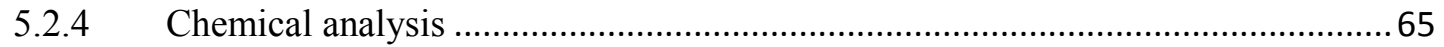

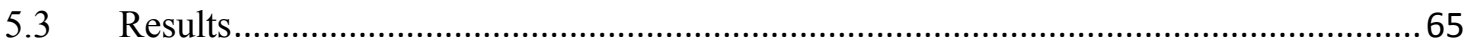




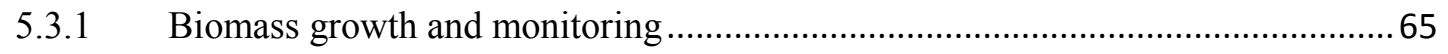

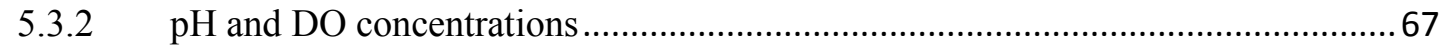

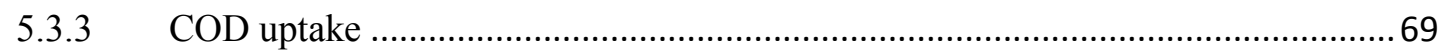

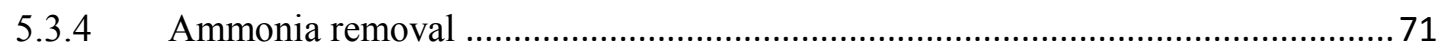

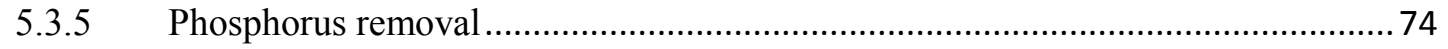

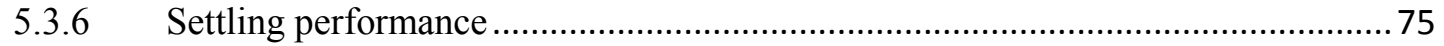

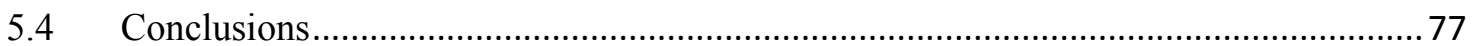

Chapter 6 Conclusions, contributions and future work .......................................79

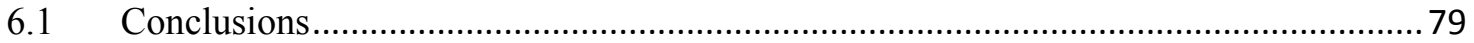

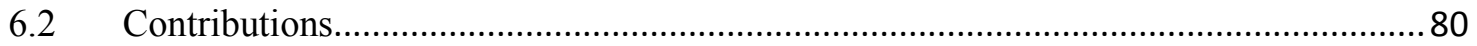

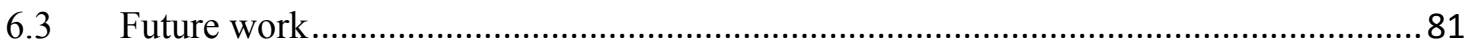

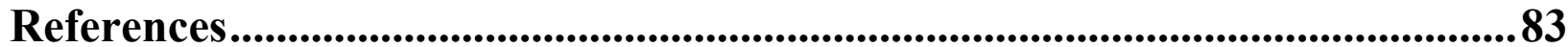

Appendices.................................................................................................................................96

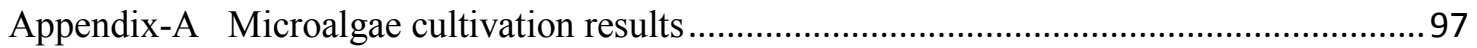

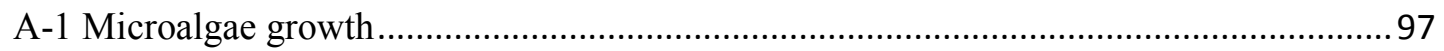

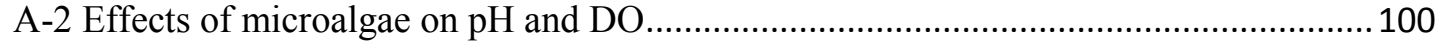

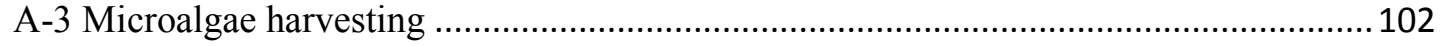




\section{List of tables}

Table 2.1 Main wastewater contaminants, their impacts and possible treatments methods.

Table 2.2 Reported studies on pathogen removal by microalgae 16

Table 2.3 Microalgae biomass harvesting methods 20

Table 2.4 Different microalgae treatment methods and wastewater types reported in the

literature 33

Table 3.1 Microalgae cultivation parameters. 37

Table 3.2 Bold's basal medium chemical composition 37

Table 3.3 Samples characteristics 39

Table 4.1 Secondary effluent and centrate properties 47

Table 4.2 Sludge settling performance 60

Table 4.3 CST for secondary effluent and centrate 60

Table 5.1 Primary effluent properties 62

Table 5.2 Start-up concentrations of microalgae and activated sludge in the tanks 64

Table 5.3 Settling performance for samples A, B and C 76 


\section{List of figures}

Figure 2.1 Main mechanisms involved in algae wastewater treatment (Oswald and

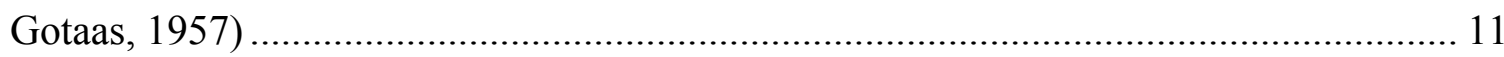

Figure 2.2 Variation of carbon forms in the environment at different $\mathrm{pH}$..................... 27

Figure 3.1 The reactors in which microalgae was cultivated, (a) microalgae suspension on

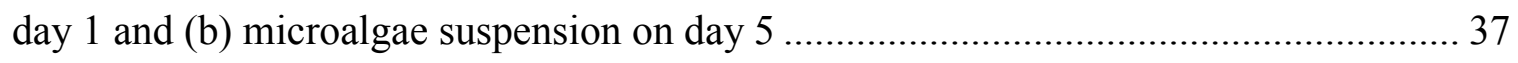

Figure 4.1 Microalgae reactor for secondary effluent and centrate ............................ 48

Figure 4.2 Microalgae growth in secondary effluent ........................................... 51

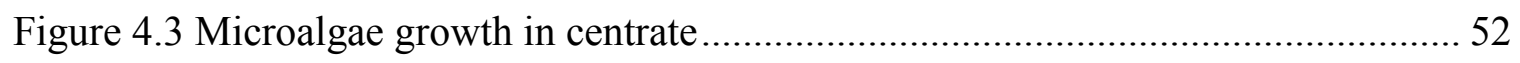

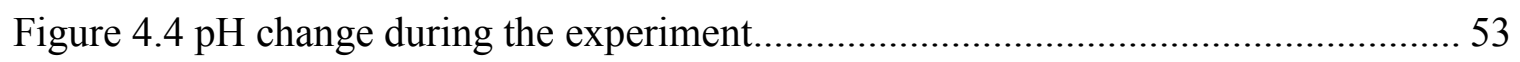

Figure 4.5 Dissolved total nitrogen concentration in secondary effluent and centrate

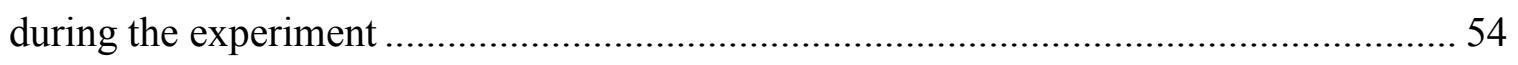

Figure 4.6 Dissolved phosphorus concentration in secondary effluent and centrate during

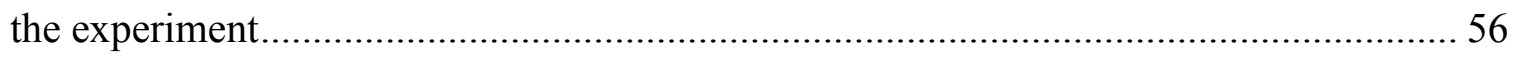

Figure 4.7 sCOD concentration in secondary effluent and centrate during the experiment 57

Figure 4.8 Total coliform removal in secondary effluent and centrate......................... 59 
Figure 5.1 Batch reactors used in the experiments. Reactor A (1000 mg/L RAS), B (500 mg/L RAS+500 mg/L microalga), C (1000 mg/L microalga) 64

Figure 5.2 Total solids concentrations over the experimental period, A (1000 mg/L RAS), B (500 mg/L RAS+500 mg/L microalga), C (1000 mg/L microalga) 66

Figure 5.3 Total volatile solids concentrations over the experimental period, A (1000 mg/L RAS), B (500 mg/L RAS+500 mg/L microalga), C (1000 mg/L microalga) ..... 67

Figure $5.4 \mathrm{pH}$ level developments along the experiment, A (1000 mg/L RAS), B (500 mg/L RAS+500 mg/L microalga), C (1000 mg/L microalga) 68

Figure 5.5 Dissolved oxygen concentration during the experimental period, A (1000 mg/L RAS), B (500 mg/L RAS+500 mg/L microalga), C (1000 mg/L microalga) 69

Figure 5.6 sCOD concentration with the time, A (1000 mg/L RAS), B (500 mg/L RAS $+500 \mathrm{mg} / \mathrm{L}$ microalga), C (1000 mg/L microalga) 71

Figure 5.7 The change in ammonia-nitrogen concentration with time, A $(1000 \mathrm{mg} / \mathrm{L}$ RAS), B (500 mg/L RAS+500 mg/L microalga), C (1000 mg/L microalga) 72

Figure 5.8 The change in nitrate concentration with time, A (1000 mg/L RAS), B (500 mg/L RAS+500 mg/L microalga), C (1000 mg/L microalga) 73

Figure 5.9 The change in phosphorus concentrations with time, A (1000 mg/L RAS), B (500 mg/L RAS+500 mg/L microalga), C (1000 mg/L microalga) 75 


\section{List of acronyms}

\begin{tabular}{|c|c|}
\hline Acronyms & Words \\
\hline ABS & Absorbance \\
\hline ATP & Adenosine triphosphate \\
\hline BBM & Bold basil medium \\
\hline CFU & Colony-forming units \\
\hline $\mathrm{CO}_{2}$ & Carbon dioxide \\
\hline COD & Chemical oxygen demand \\
\hline CST & Capillary suction time \\
\hline DO & Dissolved oxygen \\
\hline HRAP & High rate algae pond \\
\hline MF & Membrane filtration \\
\hline $\mathrm{NH}_{3}-\mathrm{N}$ & Ammonia-nitrogen \\
\hline $\mathrm{NO}_{3}-\mathrm{N}$ & Nitrate-nitrogen \\
\hline PBS & Phosphate buffered saline \\
\hline RAS & Return activated sludge \\
\hline sCOD & Soluble chemical oxygen demand \\
\hline SRT & Solid retention time \\
\hline $\mathrm{TC}$ & Total coliforms \\
\hline $\mathrm{TN}$ & Total nitrogen \\
\hline $\mathrm{P}$ & Phosphorus \\
\hline $\mathrm{TS}$ & Total solids \\
\hline TVS & Total volatile solids \\
\hline
\end{tabular}




\section{List of appendixes}

Appendix-A Microalgae cultivation results....................................97

A-1 Microalga growth................................................ 97

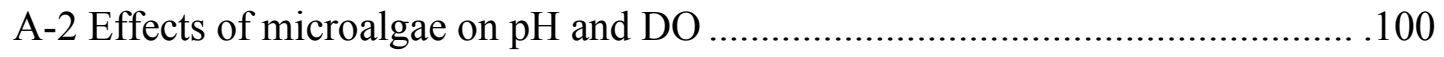

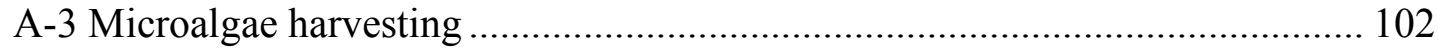




\section{Chapter 1 Introduction}

\subsection{Overview}

Wastewater has many pollutants that have to be removed before discharge to surface waters. Biological treatment mainly removes organic matter, and there are many other constituents such as nutrients, heavy metals and emerging contaminants that conventional biological treatment cannot remove to a satisfactory degree. Over the years, many modifications have been introduced to traditional treatment processes to improve the performance of treatment. However, the majority of these improvements come with some limitations as well such as high cost and increased complexity in the operation and maintenance.

Use of microalgae in wastewater treatment has been gaining attention due to its combined benefit of wastewater treatment and algae biomass production which can be used in bioenergy generation. Microalgae have been traditionally used for wastewater treatment in the following systems: waste stabilization ponds (WSPs) and high rate algae ponds (HRAPs). These two systems showed good performance in terms of removing nutrients. However, microalgae treatment has not found applications at treatment plants due to several limitations such as large surface area required for the treatment and long hydraulic retention times.

In this research, the potential use of microalgae to improve the performance of wastewater treatment at treatment plants in a simple and cost-effective way was explored. First, the use of microalgae in tertiary treatment to enhance the removal of nutrients and as a polishing step to remove additional COD and pathogens was evaluated. In addition, 
the use of microalgae when it is incorporated in an activated sludge system was examined.

\subsection{Problem statement}

Some of the current challenges in wastewater treatment are:

- Wastewater effluent typically has high concentrations of ammonia and phosphorus, which can lead to toxicity and eutrophication in surface waters.

- Advanced wastewater treatment processes necessary for the removal of nutrients require additional biological or chemical processes which increase the use of chemicals, energy needs, and sludge quantities that need to be treated and disposed off. This substantially increases the cost of treatment.

- Treatment plants have extensive energy needs, mainly due to the aeration of wastewater for aerobic biological treatment, which results in a large carbon footprint for the treatment plant.

- Disinfection byproducts formed after the disinfection of wastewater with chlorine based disinfectants.

These issues can potentially be addressed by the inclusion of microalgae based wastewater treatment processes. Microalgae can improve the wastewater treatment by:

- Removing ammonia and total nitrogen from wastewater effluent.

- Removing phosphorus from wastewater effluent.

- Decreasing the aeration requirements, $\mathrm{CO}_{2}$ emission and carbon footprint of treatment plants. 
- Decreasing the overall cost of treatment by including a simpler and sustainable treatment option.

- Decreasing the pathogen content in the final effluent without the use of chemicals.

- Decreasing sludge quantities.

- Producing algae biomass that is a source for many useful products including biogas and biofuel.

\subsection{Objective}

The overall objective of the thesis was to evaluate the potential of microalgae to improve wastewater treatment in a simple and cost-effective way without introducing major changes to existing wastewater treatment infrastructure. The study was carried out in two phases, and the more specific objectives of these phases are provided below.

\subsubsection{Phase 1}

The objective of this phase was to evaluate the efficiency of microalgae for tertiary treatment to remove nutrients $(\mathrm{N}$ and $\mathrm{P})$, remaining $\mathrm{COD}$, and pathogens from secondary wastewater effluent as well as side streams.

\subsubsection{Phase 2}

The objective of this phase was to evaluate the efficiency of microalgae when it was used in combination with the activated sludge process for the enhanced removal of COD and nutrients during biological treatment. 


\subsection{Thesis organization}

The thesis consists of the following chapters:

- Chapter 2 provides a literature review on microalgae and its use in wastewater treatment. In this chapter, the environmental and operational factors that affect microalgae treatment and previous research findings related to wastewater treatment are discussed.

- Chapter 3 presents the materials and methodologies that were used in this study.

- Chapter 4 presents results from phase one of the experimental work. It investigates the ability of microalgae to remove nutrients, $\mathrm{COD}$, and pathogens from secondary effluent and side streams.

- Chapter 5 presents results from phase two of the experimental work. It investigates the ability of microalgae to remove nutrients and COD when used together with activated sludge bacteria for biological wastewater treatment.

- Chapter 6 provides a summary of the conclusions of this study. 


\section{Chapter 2 Literature review and background}

\subsection{Introduction}

Microalgae have received substantial attention in recent years due to their effective role in the uptake of pollutants from the environment as well as their ability to produce valuable biomass that can be used in different industrial applications such as food processing, pharmaceuticals, organic fertilizer, animal feed, biofuel and biogas. In wastewater treatment applications, for instance, microalgae can assimilate nutrients, uptake $\mathrm{CO}_{2}$, provide $\mathrm{O}_{2}$ for aerobic bacteria, and produce biomass that can be used to boost biogas generation from anaerobic digesters.

Global warming and shortage in fossil fuels have been the driving forces for humans to investigate sources of renewable energy that could provide a better alternative to fossil fuels (Barbara, 2007). Microalgae biomass is an attractive option due to its high oil content compared to terrestrial crops that are used for biofuel extraction (Sheehan et al., 1998). In addition, processing of algae biomass to synthesize biofuel is more environmentally friendly since it uses less chemicals and emits less $\mathrm{CO}_{2}$.

Microalgae require nutrients which are found in wastewater to grow. Thus, wastewater can be used as a feedstock to grow microalgae, which would achieve the removal of nutrients and other pollutants from wastewater and production of microalgae biomass concurrently. As a result, microalgae are promising microorganisms that can help with wastewater treatment and production of biofuels in a sustainable way (Pienkos and Darzins, 2009; Rittmann, 2008). Microalgae treatment also enables the reuse of 
wastewater and resource recovery such as the recovery of nutrients (Noue and Pauw, 1988).

Another attractive benefit of microalgae is the assimilation of $\mathrm{CO}_{2}$. Recently, microalgae have been used for carbon sequestration due to its ability to uptake $\mathrm{CO}_{2}$ from the environment through photosynthesis process (Hende et al., 2011).

Discharge of wastewater that is rich in nutrients can cause eutrophication which is a serious problem that occurs particularly in enclosed water bodies. Eutrophication occurs when a dense bloom of algae grow in water due to presence of high concentrations of nitrogen and phosphorus, the main nutrients of concern. This reduces the level of oxygen in the aquatic system to less than the natural level that is required by aquatic organisms causing their death. The ability of microalgae to grow quickly in water that is rich in nutrients can be positively used in wastewater treatment to remove the nutrients from wastewater before discharge to the river. Thus, microalgae have the potential for alternative wastewater treatment systems with almost zero concentration of final nutrients (Ruiz et al., 2011). In addition to nutrient removal, microalgae can assimilate organic carbonaceous matter and convert it into cellular constituents such as lipids and carbohydrates (Wang et al., 2010) making microalgae treatment a better alternative to conventional wastewater treatment.

Using microalgae for wastewater treatment started in the 1950s in the United States when the idea was introduced by Oswald and Gotaas (1957). Various technologies have been used in microalgae based wastewater treatment, starting from simple stabilization- 
oxidation ponds to more advance high rate oxidation ponds (HIROP), high rate algae ponds (HIRAP) and activated algae ponds.

\subsection{Wastewater treatment}

Wastewater contains many contaminants that can harm the receiving water bodies. A brief summary of wastewater contaminants and possible treatment methods for their removal is presented in Table 2.1. Wastewater treatment consists of physical, chemical and biological processes. Physical processes remove solids by means of screening, sedimentation and filtration. Chemical processes remove wastewater constituents chemically usually through chemical precipitation. Biological processes remove the dissolved pollutants by utilizing organisms mainly consisting of bacteria.

Conventional biological treatment systems, such as activated sludge, can successfully remove dissolved organic matter but their efficiency is limited in removing contaminants such as nutrients, pathogens, heavy metals, emerging contaminants and others. Over time, many design modifications have attempted to increase the efficiency of the treatment process to obtain higher quality final effluent. One possibility is to use microalgae to increase the uptake of the nutrients. 
Table 2.1 Main wastewater contaminants, their impacts and possible treatments methods

\begin{tabular}{|c|c|c|c|}
\hline $\begin{array}{l}\text { Wastewater } \\
\text { contaminants }\end{array}$ & $\begin{array}{l}\text { Possible environmental } \\
\text { impacts }\end{array}$ & $\begin{array}{l}\text { Possible treatment } \\
\text { methods }\end{array}$ & Comment \\
\hline Organic matter & $\begin{array}{l}\text { Reduces level of } \\
\text { oxygen as a result of } \\
\text { bacterial respiration }\end{array}$ & $\begin{array}{l}\text { Mainly biological } \\
\text { biodegradation using } \\
\text { aerobic bacteria }\end{array}$ & $\begin{array}{l}\text { Conventional treatment is quite } \\
\text { efficient in removing dissolved } \\
\text { organic matter. However, there } \\
\text { are some trace organic matters } \\
\text { that are difficult to biodegrade } \\
\text { such as detergents and } \\
\text { pesticides }\end{array}$ \\
\hline $\begin{array}{l}\text { Nutrients } \\
\text { (phosphorus and } \\
\text { nitrogen) }\end{array}$ & 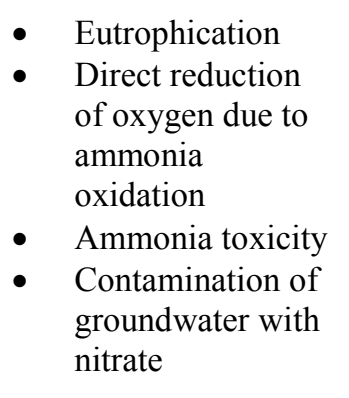 & $\begin{array}{l}\text { Nitrogen: } \\
\text { Tertiary treatment by } \\
\text { nitrification and } \\
\text { denitrification } \\
\text { Phosphorus: } \\
\text { Biological phosphorus } \\
\text { removal, chemical } \\
\text { precipitation, adsorption }\end{array}$ & $\begin{array}{l}\text { Biological nutrient removal } \\
\text { processes are effective but they } \\
\text { are complicated and expensive } \\
\text { to operate } \\
\text { Chemical processes result in } \\
\text { increased quantities of sludge }\end{array}$ \\
\hline $\begin{array}{l}\text { Pathogens } \\
\text { (coliforms as } \\
\text { indicator } \\
\text { organisms) }\end{array}$ & $\begin{array}{l}\text { - Waterborne } \\
\text { diseases }\end{array}$ & $\begin{array}{l}\text { Mainly after secondary } \\
\text { treatment by a physical } \\
\text { or chemical disinfection } \\
\text { process such as UV and } \\
\text { chlorination }\end{array}$ & $\begin{array}{l}\text { Disinfection by products, } \\
\text { particularly from chlorine and } \\
\text { chlorine derived disinfectants, } \\
\text { are of concern }\end{array}$ \\
\hline Heavy metals & $\begin{array}{l}\text { - Toxicity to aquatic } \\
\text { life } \\
\text { - Reduce biological } \\
\text { treatment } \\
\text { efficiency } \\
\text { - Concern when } \\
\text { wastewater is } \\
\text { used for irrigation }\end{array}$ & $\begin{array}{l}\text { Biological treatment by } \\
\text { adsorption, chemical } \\
\text { precipitation }\end{array}$ & $\begin{array}{l}\text { They are hard to remove from } \\
\text { wastewater, chemical } \\
\text { precipitation is widely used but } \\
\text { may limit land application of } \\
\text { final sludge. }\end{array}$ \\
\hline $\begin{array}{l}\text { Suspended } \\
\text { solid, odor, } \\
\text { color }\end{array}$ & $\begin{array}{ll} & \text { Turbidity and } \\
& \text { aesthetic problem } \\
\text { - } & \text { Sludge deposits }\end{array}$ & Tertiary treatment & \\
\hline
\end{tabular}

\subsection{Microalgae}

Algae are photosynthetic organisms that are present in most environments, such as seawater, freshwater, and soil. They, also, can live in different climate conditions such as 
very hot or cold regions. Algae are vital organisms for our food supplies since they are at the base of the food chain (Hagen, 2009). In addition to their use as a food supply, particularly in Asia, there has been a great interest in microalgae cultivation due to its high protein and lipid content that make them valuable for biofuel and biogas industries. Also, algae are important organisms as they highly contribute to $\mathrm{CO}_{2}$ fixation and oxygen generation.

There are numerous types of algae species starting from single-cell microalgae to more complex multicellular forms. Among all variety of algae organisms, microalgae are the most abundant ones in different environments (Metting, 1996). Microalgae are unicellular aquatic organisms that are able to synthesize their own food by photosynthesis. Typically, most types of microalgae are eukaryotic organisms except the blue-green algae, cyanobacteria, which belong to prokaryotic organisms. The cell size of unicellular eukaryotic algae typically is $3-30 \mu \mathrm{m}$ (Grima et al., 2003) and cyanobacteria are as small as $0.2-2 \mu \mathrm{m}$ (Chorus and Bartram, 1999).

Microalgae photosynthesis and growth rates are much higher than other terrestrial plants (Li et al., 2008). It was estimated that microalgae photosynthesis is responsible for more than half of the oxygen on earth (Tabatabaei et al., 2011). In addition, they have an ability to assimilate nutrients from the environment.

Different kinds of microalgae have been used in wastewater treatment. Wastewater characteristics and seasonal environmental conditions are some of the factors that affect the characteristics and the predominance of microalgae (Fukami et al., 1997). The most common microalgae strains in wastewater are Chlorella and Scenedesmus (Garcia et al., 
2000). Wiley et al., (2009) studied the characterizations of algae species that are present in wastewater oxidation ponds and found that algae, consisting primarily of Chlorella and Scenedesmus, composed approximately $80 \%$ of the solids inventory during the study period (Wiley et al., 2009). Chlorella species are reported to be tolerant and adaptive and can survive under different wastewater physical and biochemical conditions.

\subsection{Role of microalgae in wastewater treatment}

Microalgae based wastewater treatment was first initiated by William Oswald, when they described the basic role of microalgae in wastewater treatment as shown in Fig. 2.1 such as nutrients uptake and oxygen generation (Oswald, 1963; Oswald and Gotaas, 1957). Microalgae have recently become attractive due to their important role in uptake of pollutants from water and their ability to produce valuable biomass that can be used in different industrial applications. The first purpose of using microalgae for wastewater treatment was to remove the residual nutrients from wastewater. However, microalgae were used for other purposes as well over time. During photosynthesis, microalgae use light as an energy source and $\mathrm{CO}_{2}$ as a carbon source and uptake nitrogen and phosphorus for their cellular functions. Thus, this process helps to reduce the concentration of nutrients in wastewater and contributes to $\mathrm{CO}_{2}$ mitigation. In addition, microalgae produce oxygen, as a byproduct for photosynthesis, which can be used by aerobic bacteria to biodegrade organic pollutants present in the wastewater. In fact, microalgae can help to reduce the need for mechanical aeration during wastewater treatment. Microalgae can also work in the absence of light as heterotrophic organism and use oxygen to assimilate organic carbon. In addition, microalgae treatment provides an 
environment that increases the death of pathogenic organisms due to elevated $\mathrm{pH}$ and antibacterial substances that may be excreted by microalgae (Polprasert et al., 1983)

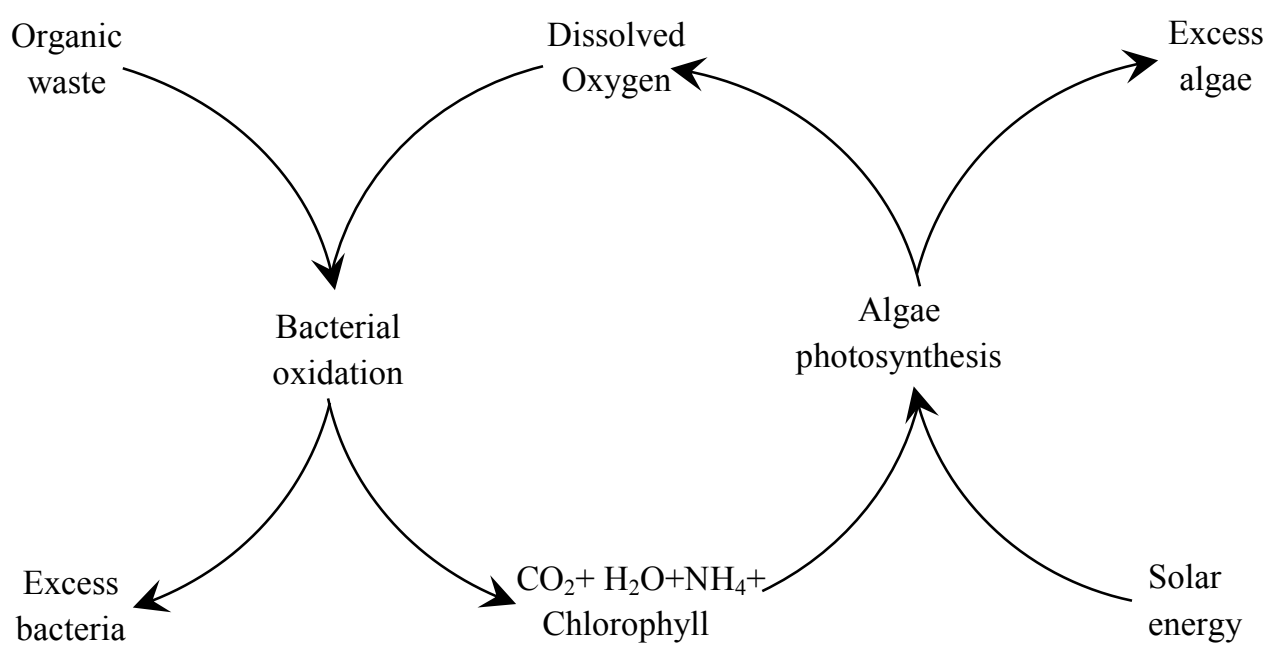

\section{Figure 2.1 Main mechanisms involved in algae wastewater treatment (Oswald and Gotaas, 1957)}

\subsubsection{Nutrients uptake}

Researches have shown that microalgae have very good ability to assimilate nutrients $(\mathrm{N}$ and P) from wastewater. These are some mechanisms in which microalgae can help to reduce nutrient concentration in wastewater:

- Diffusion of substances through the cell wall is one direct mechanism that helps microalgae in nutrients assimilation. The diffusion rate may depend on the thickness of the boundary layer of water that is directly surrounding the cell. Turbulence is essential to improve mass transfer rate of the nutrients (Mostert and Grobbelaar, 1987; Borowitzka, 1998). 
- Precipitation as a result of high $\mathrm{pH}$ level, such as phosphorus precipitation. Microalgae normally consume $\mathrm{CO}_{2}$ as a carbon source but if it is not available, it will consume bicarbonate $\left(\mathrm{HCO}_{3}{ }^{-}\right)$that need carbonic anhydrase enzyme to convert it to $\mathrm{CO}_{2}$ and the $\mathrm{pH}$ will increase according to the following chemical reaction formula:

$\mathrm{HCO}_{3}{ }^{-} \rightarrow \mathrm{CO}_{2}+\mathrm{OH}^{-}$

This increase in $\mathrm{pH}$ can alter the water chemistry and cause phosphorus to precipitate due to reaction with the available cations.

- Stripping of ammonia as a result of elevated $\mathrm{pH}$.

Nitrogen is widely available in wastewater in many forms. However, microalgae can assimilate only the inorganic nitrogen. Ammonia is the most favourable nitrogen form for assimilation. After depletion of ammonia $\left(\mathrm{NH}_{3}-\mathrm{N}\right)$ in wastewater, microalgae may start to assimilate nitrate $\left(\mathrm{NO}_{3}{ }^{-}\right)$as a source of nitrogen for their cells. Also, some microalgae such as cyanobacteria are able to assimilate nitrogen gas (Bhaya et al., 2002) and contribute to nitrogen gas fixation.

Phosphorus is the second essentail nutrient for microalgae. It is an important element that comprises $1 \%$ of the cell's dry weight (Brown and Shilton, 2014). However, microalgae can uptake more than what they need through their ability to synthesize and accumulate polyphosphate in their cells.

One important factor that affects nutrient removal in microalgae based wastewater treatment is the hydraulic retention time (Larsdotter, 2006; Woertz et al., 2009). Microalgae can reduce the nutrients concentration in wastewater by direct removal and 
indirect removal. Direct removal involves assimilation of these nutrients by microalgae cells, while indirect removal involves removal of nutrients by precipitation and stripping as a result of elevated $\mathrm{pH}$ level caused by microalgae activity. Therefore, longer retention times improve nutrient removal.

\subsubsection{COD uptake}

Microalgae normally use inorganic carbon source. $\mathrm{CO}_{2}$ is the first choice for microalgae and bicarbonate $\left(\mathrm{HCO}_{3}{ }^{-}\right)$is the second choice in the absence of $\mathrm{CO}_{2}$. However, $\mathrm{HCO}_{3}{ }^{-}$ needs the enzyme carbonic anhydrase to convert it into $\mathrm{CO}_{2}$ (Borowitzka, 1998; Oswald, 1988). Some microalgae species such as Chlorella species can function differently in response to the environmental conditions. They can grow under phototrophic conditions in which they use $\mathrm{CO}_{2}$ as the carbon source. Also, they can grow under heterotrophic conditions in which it uses dissolved organic carbon such as acetate, sugar, and organic acids as a carbon source (Borowitzka, 1998). Microalgae heterotrophic growth may be seen in two cases:

- Chemoheterotrophic condition: in the absence of the light and at low $\mathrm{CO}_{2}$ concentration, microalgae can use the dissolved organic carbon as both energy source and carbon source causing the concentration of COD to decrease.

- Photoheterotrophic condition: under illumination and depletion of $\mathrm{CO}_{2}$ concentration, microalgae can use light as an energy source and dissolved organic carbon as carbon source. 


\subsection{3 $\mathrm{O}_{2}$ release and $\mathrm{CO}_{2}$ fixation}

Mechanical aeration is one of the costly processes in wastewater treatment. It can account for $50 \%$ of the total treatment cost (Tchobanoglous et al., 2003). It was roughly estimated by Oswald, (2003) that each one kWh of electricity can facilitate the removal of one $\mathrm{kg}$ of $\mathrm{BOD}$, while one $\mathrm{kg} \mathrm{BOD}$ removed due to photosynthetic oxygenation requires no energy input and produce algae biomass that can give enough biogas to generate one kWh of electricity (Oswald et al., 2003). Thus, using microalgae in the treatment process can provide an environmentally friendly aeration method and decrease the need for the mechanical aeration. By using light as an energy source, microalgae uptake $\mathrm{CO}_{2}$ from the environment as an essential carbon source to synthesize sugar for their biomass growth and produce $\mathrm{O}_{2}$ as a byproduct according to the following overall stoichiometric formula for photosynthesis:

$$
6 \mathrm{H}_{2} \mathrm{O}+6 \mathrm{CO}_{2}+\text { light } \rightarrow \mathrm{C}_{6} \mathrm{H}_{12} \mathrm{O}_{6}+6 \mathrm{O}_{2}
$$

Oxygen produced by microalgae can support aerobic heterotroph bacteria in degrading the complex organic compounds in wastewater (i.e., lipids, proteins, carbohydrates). Also, it can facilitate the nutrients removal through nitrification and denitrification process.

Microalgae can assimilate $\mathrm{CO}_{2}$ that is released by bacterial respiration and hence help reduce its emission to the atmosphere. Microalgae have an ability to fix $\mathrm{CO}_{2}$, using solar energy, that can be 10\% more than for terrestrial plants (Singh and Ahluwalia, 2013). Dry biomass of microalgae contains up to $46 \%$ carbon, $10 \%$ nitrogen, and $1 \%$ phosphorus and microalgae need to uptake $1.7 \mathrm{Kg}$ of $\mathrm{CO}_{2}$ to grow and obtain $1 \mathrm{Kg}$ of dry weight biomass 
(Hu et al., 2008). As a result, using microalgae in wastewater treatment can significantly contribute to reducing $\mathrm{CO}_{2}$ emissions from wastewater treatment plants.

\subsubsection{Indicator bacteria removal}

Microalgae based wastewater treatment ponds showed high efficiency in removing indicator bacteria and pathogens. Wastewater pathogens include a wide range of organisms such as viruses, bacteria, parasite and protozoa. Disinfection performance is usually evaluated by measuring the disinfection rate of indicator organisms such as total coliforms. Several studies have showed that microalgae can effectively increase the mortality of coliform bacteria through direct and indirect means. Table 2.2 is a summary of some studies on the effect of algae on the survival of pathogens. Coliform bacteria reduction is a complicated phenomenon that may be affected by different physicalbiochemical reactions (Polprasert et al., 1983) and environmental factors such as algae concentration, organic loading and solar irradiation. Several hypotheses were made to explain the causes of bacterial reduction, including:

- Presence of antibacterial substances excreated by algae,

- High $\mathrm{pH}$ levels common in algae-based treatment ponds,

- Production of toxic extracellular compounds by certain species of algae,

- Depletion of nutrients and organic matter in wastewater, mainly the biodegradable fraction, since it is the carbon and energy source essential to the growth of heterotrophic bacteria, including coliforms, and

- High oxidation reduction potential in algal-bacteria cultures. 
Table 2.2 Reported studies on pathogen removal by microalgae

\begin{tabular}{|c|c|c|c|c|}
\hline $\begin{array}{l}\text { Indicator } \\
\text { organism }\end{array}$ & microalgae strain & Reactor setup & Findings & References \\
\hline $\begin{array}{l}\text { Total coliform } \\
\text { and E.coli }\end{array}$ & $\begin{array}{l}\text { Scenedesmus } \\
\text { obliquus }\end{array}$ & $\begin{array}{l}\text { Small ponds of } \\
4.5 \mathrm{~m}^{2} \text { with a depth } \\
\text { of } 25 \mathrm{~cm} \text {, containing } \\
\text { biologically treated } \\
\text { domestic sewage, } 2- \\
4 \text { days }\end{array}$ & $\begin{array}{l}\text { They obtained a } \\
\text { reduction of } E . c o l i \text { from } \\
10^{10} \text { E.coli } 100 \mathrm{~mL}^{-1} \text { to } \\
10^{5} \text { E.coli } 100 \mathrm{~mL}^{-1} \text { in } \\
\text { the treated effluent of } \\
\text { HRAP }\end{array}$ & $\begin{array}{l}\text { (Sebastian } \\
\text { and Nair, } \\
\text { 1984) }\end{array}$ \\
\hline Escherichia coli & $\begin{array}{l}\text { Mixed culture of } \\
\text { algae }\end{array}$ & $\begin{array}{l}\text { Outdoor ponds } \\
\text { operating on } \\
\text { synthetic } \\
\text { wastewater mixed } \\
\text { with acetate as a } \\
\text { carbon source }(260 \\
\left.\mathrm{kg} \mathrm{COD} \mathrm{ha}^{-1} \mathrm{~d}^{-1}\right) \\
\text { and a depth ranging } \\
\text { from } 12 \text { to } 34 \mathrm{~cm} .\end{array}$ & $\begin{array}{l}\text { Die-off constants }(\mathrm{Kd}) \\
\text { of } 0.35-2.34 \mathrm{~d}^{-1} \text { were } \\
\text { obtained for } E . c o l i \text {, also, } \\
\text { they observed a } \\
\text { significant effects of } \mathrm{pH} \text {, } \\
\text { UV irradiance and pond } \\
\text { depth on Kd. }\end{array}$ & $\begin{array}{l}\text { (Fallowfield } \\
\text { et al., 1996) }\end{array}$ \\
\hline $\begin{array}{l}\text { Total coliforms, } \\
\text { bifidobacteria, } \\
\text { and C.perfringens }\end{array}$ & $\begin{array}{l}\text { Mixed culture of } \\
\text { algae }\end{array}$ & $\begin{array}{l}\text { Stabilization pond, } \\
\text { high rate algae } \\
\text { pond, and free } \\
\text { water macrophyte } \\
\text { system, with } \\
\text { retention times of } \\
24,5 \text { and } 3 \text { days } \\
\text { respectively. }\end{array}$ & $\begin{array}{l}\text { Macrophyte system had } \\
\text { a higher removal rate } \\
\text { compared to } \\
\text { stabilization pond and } \\
\text { high rate algae pond. } \\
\text { The highest efficiencies } \\
\text { in the removal of total } \\
\text { coliforms ranged from } \\
98.68 \% \text { for stabilization } \\
\text { pond to } 99.48 \% \text { for the } \\
\text { macrophyte process. }\end{array}$ & $\begin{array}{l}\text { (Garcia and } \\
\text { Becares, } \\
\text { 1997) }\end{array}$ \\
\hline $\begin{array}{l}\text { Total coliforms, } \\
\text { Pseudomonas } \\
\text { aeruginosa, and } \\
\text { Streptococcus } \\
\text { faecalis }\end{array}$ & $\begin{array}{l}\text { Scenedesmus } \\
\text { obliquus and } \\
\text { Chlorella vulgaris }\end{array}$ & $\begin{array}{l}\text { A pilot scale } \\
\text { oxidation channel } \\
\text { bioreactor using a } \\
\text { carrousel system }\end{array}$ & $\begin{array}{l}\text { It was demonstrated that } \\
\text { the level of wastewater } \\
\text { contamination could be } \\
\text { predicted based on the } \\
\text { bacterial and algae } \\
\text { composition }\end{array}$ & $\begin{array}{l}\text { (O'Farrill et } \\
\text { al., 2003) }\end{array}$ \\
\hline Fecal coliform & $\begin{array}{l}\text { Mixed culture of } \\
\text { algae }\end{array}$ & $\begin{array}{l}\text { Batch reactors of } \\
250 \mathrm{~mL} \text { of raw } \\
\text { domestic } \\
\text { wastewater were } \\
\text { introduced into four } \\
\text { sets of sterile } \\
\text { Erlenmeyer flasks. } \\
\text { Each set consisted } \\
\text { of six flasks }\end{array}$ & $\begin{array}{l}\text { Significant fecal } \\
\text { coliform die-off was } \\
\text { obtained. The optimum } \\
\text { algal concentration for } \\
\text { fecal coliform die-off in } \\
\text { this experiment was } \\
1199 \mu \mathrm{g} \mathrm{L}^{-1}\end{array}$ & $\begin{array}{l}\text { (Ansa et al., } \\
\text { 2008) }\end{array}$ \\
\hline $\begin{array}{l}\text { Total coliforms, } \\
\text { fecal coliforms, } \\
\text { fecal }\end{array}$ & $\begin{array}{l}\text { Mixed culture of } \\
\text { algae }\end{array}$ & $\begin{array}{l}\text { Constructed } \\
\text { wetlands (sub- } \\
\text { surface and free }\end{array}$ & $\begin{array}{l}\text { Generally constructed } \\
\text { wetlands were more } \\
\text { efficient than algae- }\end{array}$ & $\begin{array}{l}\text { (Garcia et } \\
\text { al., 2008) }\end{array}$ \\
\hline
\end{tabular}




\begin{tabular}{|c|c|c|c|c|}
\hline $\begin{array}{l}\text { Streptococci, } \\
\text { Clostridium } \\
\text { perfringens, and } \\
\text { Staphylococci }\end{array}$ & & $\begin{array}{l}\text { water surface) and } \\
\text { algae-based systems } \\
\text { (HRAP) and } \\
\text { maturation pond } \\
\text { (MP) }\end{array}$ & $\begin{array}{l}\text { based systems when } \\
\text { considering both, } \\
\text { efficiencies in \% and } \\
\text { surface removal rates }\end{array}$ & \\
\hline Escherichia coli & $\begin{array}{l}\text { Chlorella sp. and } \\
\text { Anabaena sp. as } \\
\text { the most dominant } \\
\text { algal species at } \\
\text { the experiment } \\
\text { sites. There were } \\
\text { other algae in } \\
\text { minimal quantities }\end{array}$ & $\begin{array}{l}\text { Escherichia coli } \\
\text { placed in dialysis } \\
\text { tubes in an } \\
\text { eutrophic lake at } \\
\text { different depths and } \\
\text { locations. }\end{array}$ & $\begin{array}{l}\text { Algae are significantly } \\
\text { reducing } E \text {. coli } \\
\text { contamination in } \\
\text { eutrophic lakes through } \\
\text { increased oxygenation } \\
\text { and pH elevation. }\end{array}$ & $\begin{array}{l}\text { (Ansa et al., } \\
\text { 2011) }\end{array}$ \\
\hline $\begin{array}{l}\text { Thermo-tolerant } \\
\text { coliforms (TTC) }\end{array}$ & $\begin{array}{l}\text { Immobilized } \\
\text { Chlorella }\end{array}$ & $\begin{array}{l}\text { Batch reactor } \\
\text { consisted of } \\
\text { columns of } \\
\text { immobilized algae } \\
\text { in alginate beads } \\
\text { suspended in } \\
\text { distilled water. The } \\
\text { columns were } \\
\text { eluted with the TTC } \\
\text { suspension to } \\
\text { replace the distilled } \\
\text { water. }\end{array}$ & $\begin{array}{l}\text { Columns of Chlorella } \\
\text { cells immobilized in } \\
\text { alginate beads removed } \\
5 \text { log concentrations of } \\
\text { TTC in } 6 \mathrm{~h} \text { and } 11 \text { logs } \\
\text { in } 12 \mathrm{~h} \text {. }\end{array}$ & $\begin{array}{l}\text { (Pearson et } \\
\text { al., 2011) }\end{array}$ \\
\hline
\end{tabular}

\subsubsection{Biomass generation}

Most microalgae are fast growing and can produce valuable biomass that can be used in different industrial applications. Microalgae produce biomass that has a high protein and lipid content thus has a high energy value. For its biomass, microalgae have been successfully cultivated in large-scale reactors in artificial broth medium for commercial purposes. Production of algae biomass in wastewater treatment provides a cost-effective way to nutrients recycle and energy recovery. The nutrients that are needed by both bacteria and microalgae are abundantly present in wastewater. Thus, concurrent wastewater treatment and biomass production can readily occur (Gutzeit et al., 2005; Munoz and Guieysse, 2006). However, wastewater is not usually utilized for the purpose of commercial production of microalgae biomass (Rawat et al., 2011). Using microalgae 
in wastewater treatment can significantly improve the biomass quantity making it costeffective for a wide range of industrial applications, especially for biogas and biofuel production. Algal biomass grown on wastewater may not be favorable for some industries such as food processing, or even its use as fertilizer if the wastewater has high levels of heavy metals and other contaminants.

\subsubsection{Harvesting strategies}

Effective wastewater treatment occurs when biomass is efficiently removed from wastewater effluent. Harvesting is one of the most costly and labor extensive processes in microalgae based wastewater treatment, limiting the extent of this technology (Noue and Pauw, 1988). The harvesting process may account for $30 \%$ of total microalgae biomass production cost (Wiley et al., 2009; Bare et al., 1975; Shelef et al., 1984). Settling of microalgae are affected by many factors including the microalgae strain and the operational parameters such as hydraulic retention time and solids retention time (Valigore et al., 2012). Typically, microalgae harvesting process consists of a liquid-solid separation phase, dewatering and drying. Some harvesting methods that have been used in the past are listed in Table 2.3 with the advantages and disadvantages listed for each.

There were many efforts on developing technologies that can help with the harvesting of microalgae biomass such as:

- Using monoalgal cultures that contain multicellular species or species with selfaggregation capacity. Monoalgal cultures help improve settling performance of microalgae and thus reduce the cost of the harvesting. 
- Using algae strains with high flotation capacity or induce algae flotation of a given strain by providing the appropriate environmental conditions.

- The most advanced approach to improve microalgae harvesting is the application of mixed culture of bacteria and microalgae that have high level of self-settling performance (Su et al., 2011). Using a natural mix culture of bacteria and microalgae has been proven to have a good effect on the aggregation of the flocs and the settling performance of biomass. As an example, using a mixed culture of microalgae strain Chlorella with activated sludge can result in good wastewater treatment and better biomass settleability (Gutzeit et al., 2005).

- Another method that helps in easy harvesting is the use of immobilization microalgae technique. Although this technology has advantages regarding the harvesting process, it has the disadvantage of high operational and maintenance costs.

In spite of the high cost of harvesting process for microalgae based wastewater treatment, it may be a preferable method over other treatment methods in tropical and subtropical regions where suitable environmental conditions are present (Noue and Pauw, 1988). Naturally available light and temperature make microalgae based wastewater treatment more cost effective. In addition, in cold regions where the required amounts of light or heat may need to be provided during winter days, the high cost of the harvesting process can be recovered from the sale of microalgae biomass. 
Table 2.3 Microalgae biomass harvesting methods

\begin{tabular}{|c|c|c|c|c|}
\hline \multicolumn{2}{|c|}{ Harvesting Technology } & $\begin{array}{l}\text { Operation } \\
\text { mechanism }\end{array}$ & Advantage & Disadvantage \\
\hline \multicolumn{2}{|c|}{ Centrifugation } & $\begin{array}{l}\text { It can be done by } \\
\text { using mechanical } \\
\text { centrifuges }\end{array}$ & $\begin{array}{l}\text { Reliable, high solids } \\
\text { concentration, rapid, } \\
\text { and universal (Mutanda } \\
\text { et al., 2011) }\end{array}$ & $\begin{array}{l}\text { Is not economically } \\
\text { feasible for large } \\
\text { scale harvesting due } \\
\text { to energy intensive } \\
\text { and high cost } \\
\text { (Pittman et al., } \\
\text { 2011) }\end{array}$ \\
\hline \multirow{2}{*}{ Flocculation } & Chemoflocculation & $\begin{array}{l}\text { The addition of } \\
\text { chemical } \\
\text { flocculants such as } \\
\text { lime and alum }\end{array}$ & Efficient and reliable & $\begin{array}{l}\text { Expensive and } \\
\text { increase the effluent } \\
\text { salinity and convert } \\
\text { algal biomass into } \\
\text { waste sludge that } \\
\text { must be disposed of } \\
\text { (Hoffmann, 1998) }\end{array}$ \\
\hline & Bioflocculation & $\begin{array}{l}\text { Is the natural } \\
\text { aggregation of the } \\
\text { flocs, it can occur } \\
\text { due to the } \\
\text { microalgal release } \\
\text { of long-chain } \\
\text { polymers }\end{array}$ & $\begin{array}{l}\text { Environmentally } \\
\text { friendly and produce } \\
\text { biomass valuable for } \\
\text { various applications }\end{array}$ & $\begin{array}{l}\text { Still poorly } \\
\text { understood }\end{array}$ \\
\hline \multicolumn{2}{|c|}{ Gravity sedimentation } & $\begin{array}{l}\text { Allows algae to } \\
\text { settle down by the } \\
\text { effect of gravity. } \\
\text { Sometimes it } \\
\text { needs to use } \\
\text { flocculation in } \\
\text { conjunction to } \\
\text { improve the } \\
\text { settling } \\
\text { performance }\end{array}$ & $\begin{array}{l}\text { Works for various types } \\
\text { of algae and is highly } \\
\text { energy efficient }\end{array}$ & $\begin{array}{l}\text { Slow, unreliable } \\
\text { and the effluent } \\
\text { may need to be } \\
\text { filtered }\end{array}$ \\
\hline \multicolumn{2}{|l|}{ Filtration } & $\begin{array}{l}\text { Vacuum filtration } \\
\text { or membrane } \\
\text { micro-filtration or } \\
\text { ultrafiltration for } \\
\text { effective } \\
\text { harvesting } \\
\text { (Brennan and } \\
\text { Owende, 2009) }\end{array}$ & $\begin{array}{l}\text { Reliable, high solids } \\
\text { concentration }\end{array}$ & $\begin{array}{l}\text { These methods are } \\
\text { costly, energy } \\
\text { intensive and } \\
\text { require frequent } \\
\text { membrane } \\
\text { replacements (as a } \\
\text { result of fouling) } \\
\text { and pumping of the } \\
\text { biomass (Pittman et } \\
\text { al., 2011) }\end{array}$ \\
\hline \multicolumn{2}{|c|}{ Dissolved air flotation } & $\begin{array}{l}\text { The mechanism of } \\
\text { action is } \\
\text { interaction with } \\
\text { the negatively } \\
\text { charged }\end{array}$ & $\begin{array}{l}\text { Floatation of algal } \\
\text { biomass has shown } \\
\text { promise in terms of } \\
\text { harvesting smaller and } \\
\text { unicellular algae in }\end{array}$ & $\begin{array}{l}\text { Flocculants are } \\
\text { usually required } \\
\text { because direct air } \\
\text { application doesn't } \\
\text { provide a good }\end{array}$ \\
\hline
\end{tabular}




\begin{tabular}{|l|l|l|l|}
\hline & $\begin{array}{l}\text { hydrophilic } \\
\text { surfaces of algal } \\
\text { cells }\end{array}$ & $\begin{array}{l}\text { laboratory scale trials } \\
\text { (Rawat et al., 2011). } \\
\text { Also, it is proven in } \\
\text { large scale. }\end{array}$ & $\begin{array}{l}\text { suspended solid } \\
\text { reduction (Bare et } \\
\text { al., 1975) }\end{array}$ \\
\hline Immobilization of microalgae & $\begin{array}{l}\text { Microalgae } \\
\text { immobilized in } \\
\text { polymeric material } \\
\text { such as } \\
\text { carrageenan, } \\
\text { chitosan, or } \\
\text { alginate }\end{array}$ & $\begin{array}{l}\text { Effective in reducing } \\
\text { total solids }\end{array}$ & $\begin{array}{l}\text { These matrices are } \\
\text { weak and costly, } \\
\text { which has limited } \\
\text { their large-scale } \\
\text { application }\end{array}$ \\
\hline
\end{tabular}

There are two important concerns about the harvesting processes:

- Degradation of microalgae biomass during the drying process. About $30 \%$ of biomass (i.e., in appearance, nutritional value, texture, and the digestibility of the final products) may be degraded during the drying process (Noue and Pauw, 1988).

- Toxicity effect of some harvesting methods. This is particularly important for microalgae biomass that was intended to be used in food industry.

Considering these concerns, the most environmental friendly harvesting method is bioflocculation as it involves formation of exocellular polymers (cellular aggregates) that helps natural flocculation of small particles. Bioflocculation is followed by gravity sedimentation for a simple and low cost harvesting process (Noue and Pauw, 1988; Nurdogan and Oswald, 1995; Oh et al., 2001). However, for microalgae that are small in size and that rapidly grow this method may be not efficient (Munoz and Guieysse, 2006). As a result, researchers have found that the best settling can be obtained when a good combination of microalgae and bacteria, with natural tendency to settle are implemented (Olguin, 2003; Su et al., 2011; Su et al., 2012). 


\subsection{Effect of operational factors on microalgae growth}

Good growth of microalgae can determine the efficiency of the treatment process. To have a good growth, it is important to understand and control the essential factors that have direct impact on microalgae growth. Examples of operational factors are the design of the reactor, mixing and aeration, availability of the light and temperature. The growth rate of microalgae is affected by many environmental and operational factors such availability of nutrients and carbon dioxide in the wastewater, composition of the bacteria-algae population, competition between species, and the presence of grazing organisms and viruses.

\subsubsection{Effect of light}

Light is one of the important factors that directly affect microalgae growth since it represents the energy source for the cell when microalgae grow as phototrophic organisms. Maximum algae growth yield is achieved when there is saturated light in the environment. However, food synthesis in the algal cell depends on the efficiency of converting the light to energy. The light energy is converted to chemical energy that is needed by the algal cell; however, about only $10 \%$ of the light is converted to chemical energy, and the remaining escapes as heat (Oswald, 1988). Also, it was mentioned in the literature that only $2 \%$ of the light energy is converted into chemical energy (Fontes et al., 1987). Through photosynthesis, microalgae need light to produce adenosine triphosphate (ATP) that is used as an energy source for cell synthesis and maintenance. Also, microalgae need a period of dark to allow chemoautotrophic growth of algal cell to produce essential molecules for cell growth (Al-Qasmi et al., 2012). Light duration, 
intensity, and wavelength are important parameters that affect the algae growth (Carvalho et al., 2011).

In northern parts of the world, such as Canada, it is hard to rely on the sun light as the dark period throughout the year is longer than the light period. As a result, providing artificial light is needed for growing microalgae. This may reduce the feasibility of using microalgae for wastewater treatment because of high energy input and subsequent high operational cost. In addition, there are some factors that reduce light availability to microalgae. The depth of the cultivation tank can be a factor that affects light availability. Microalgae in the deeper part of the cultivation tank are light limited since photosynthetic active radiation is absorbed by water. Microalgae dense culture, also, can limit the light availability because of self-shading. Reducing the depth of the tank and providing mixing is a better solution to overcome these two factors that cause light limitation.

Over time, there were many attempts to overcome the light limitation. One of the outputs for these attempts was adapting microalgae that work under mixtrophic condition. Microalgae can work as a photoautotrophic and a heterotrophic organism in the same media when it is provided with light:dark period and carbon source. Under this condition, microalgae is called mixotrophic organisms that are capable to use light as energy source and $\mathrm{CO}_{2}$ as carbon source to reproduce in light periods while it uses dissolved organic carbon as energy and carbon source when it is dark. Growing mixotrophic microalgae results in many benefits (Cheirsilp and Torpee, 2012) such as:

- Higher cells concentrations (higher biomass) that have higher lipid content which can be converted to biodiesel and biogas. 
- Decrease the cost of the electricity for microalgae growth as there will be a light: dark period and continuous light will not be needed.

- Keep pH levels in almost neutral status as there is $\mathrm{CO}_{2}$ produced and consumed at the same time.

\subsubsection{Effect of temperature}

Microalgae should be provided with appropriate temperature in order to have a good growth. Very high or low temperature can have a negative effect on the microalgae growth and may cause growth inhibition. Increasing temperature can promote algal growth until it reaches the optimum temperature (Borowitzka, 1998 and Fontes et al., 1998). For example, Munoz et al. (2004), showed that an increase in the temperature from 25 to $30^{\circ} \mathrm{C}$ could double the removal efficiency when used a symbiotic microcosm formed by $C$. sorokiniana and $R$. basilensis strain. However, very high temperatures could reduce the growth rate of microalgae especially in humid climate when evaporation is low. In cold climate, low temperature may limit algae growth but there are some microalgae that can survive cold weather such as blue-green algae (cyanobacteria). In addition, high light intensity associated with low temperature is also another concern that causes growth inhibition (Larsdotter, 2006). However, in optimum temperature algal growth would not be affected by high light intensities (Borowitzka, 1998).

The optimum temperature for growth varies from species to species (Goldman and Carpenter, 1974). Some microalgae species can have good growth in high temperature while some species can tolerate very low temperature. Razzak et al. (2013) have reported that the decrease of $15^{\circ} \mathrm{C}$ below the optimum temperature may not affect the growth of 
most microalgae species. In contrast, increasing the temperature by 2 to $4{ }^{\circ} \mathrm{C}$ may inhibit the growth of microalgae (Richmond, 1999).

\subsubsection{Effect of aeration and mixing}

Aeration is an important process in wastewater treatment. It provides oxygen and promotes the aerobic degradation of organic matter by aerobic heterotrophic bacteria and other microorganisms. Although, microalgae provide some oxygen for heterotrophic bacteria, treatment of wastewater with microalgae may need aeration for three purposes: respiration of microorganisms, source of mixing and as a source of $\mathrm{CO}_{2}$. Air bubbling is one way that provides both aeration and mixing at the same time. On the other hand, very high oxygen concentrations can adversely affect microalgae growth by causing photooxidation damage to the cells and can result in photoinhibition and reduction in algal productivity. As a result, it is preferable to agitate the wastewater mechanically instead of aeration for shallow systems so that heterotrophic organisms can uptake the atmospheric oxygen through the interface between the air and the wastewater.

Mechanical mixing is a method used to provide turbulence for algal cell. Mixing should be provided in a gentle way in order to prevent any damage to algal cells. Also, mixing device should be carefully selected as some of the mechanical mixing devices apply shear stress on the microalgae (Barbosa and Wijffels, 2004; Mitsuhashi et al., 1995). Mixing is important in microalgae treatment because it helps in good distribution of the nutrients and other wastewater constituents, prevents the light limitation due to biomass shading, limits the formation of anaerobic zone and improves the mass transfer between the cells and the external environment (Grobbelaar, 2000). At lab scale experiments, the 
recommended mixing rate is $100-200 \mathrm{rpm}$. In the field (i.e., open pond and HRAP), paddle wheels are commonly used mixing devices with horizontal water velocities around $5-20 \mathrm{~cm} \mathrm{~s}^{-1}$ as too high mixing is not recommended as it damages the algal cell (Borowitzka, 1998; Benemann, 1979). Also, mixing with paddle wheels promotes selfaggregation and settling performance of microalgae after remove from the mixing pond (Oswald, 1988).

\subsubsection{Effect of carbon and nutrients}

Through photosynthesis, microalgae uptake nitrogen and phosphorus and use light and $\mathrm{CO}_{2}$ to make their own organic molecules. For optimum growth, microalgae need a certain ratio of carbon, nitrogen, and phosphorus. The optimum C: N: P ratio is about 106: 10: 1. High ratios of N: P (i.e., about 30:1) suggest P limitation, whereas low ratios of N: P about 5:1 suggest N- limitation (Darley, 1982). Based on the typical wastewater concentrations of these nutrients, phosphorus was found to rarely affect microalgae growth, while the nitrogen was found to have an effect. Overall, wastewater has abundant concentrations of nitrogen and phosphorus and they do not seem to be an issue for microalgae growth. Microalgae growth in wastewater is more likely limited by carbon and light (Noue et al., 1992).

Most microalgae can utilize both inorganic and organic carbon. The very favorable form of carbon, however, is the inorganic one in the presence of the light. When illuminated, microalgae use $\mathrm{CO}_{2}$ as a carbon source. The availability of dissolved $\mathrm{CO}_{2}$ in wastewater varies greatly with $\mathrm{pH}$ as shown in Figure 2.2. At lower $\mathrm{pH}$ values, $\mathrm{CO}_{2}$ is abundant, while at higher $\mathrm{pH}$ values (i.e., greater than 8 ), there will be a deficit in $\mathrm{CO}_{2}$ 
concentration and most of the carbon will be in the form of carbonate $\left(\mathrm{CO}_{3}{ }^{2-}\right)$ which cannot be uptaken by microalgae (Borowitzka, 1998) unless converted to $\mathrm{CO}_{2}$ by the enzyme carbonic anhydrase (CA) (Badger et al. 1994).

Low $\mathrm{CO}_{2}$ concentration has a negative effect on algal growth. However, this is not an issue in wastewater treatment since $\mathrm{CO}_{2}$ is always available as a byproduct of bacterial respiration.

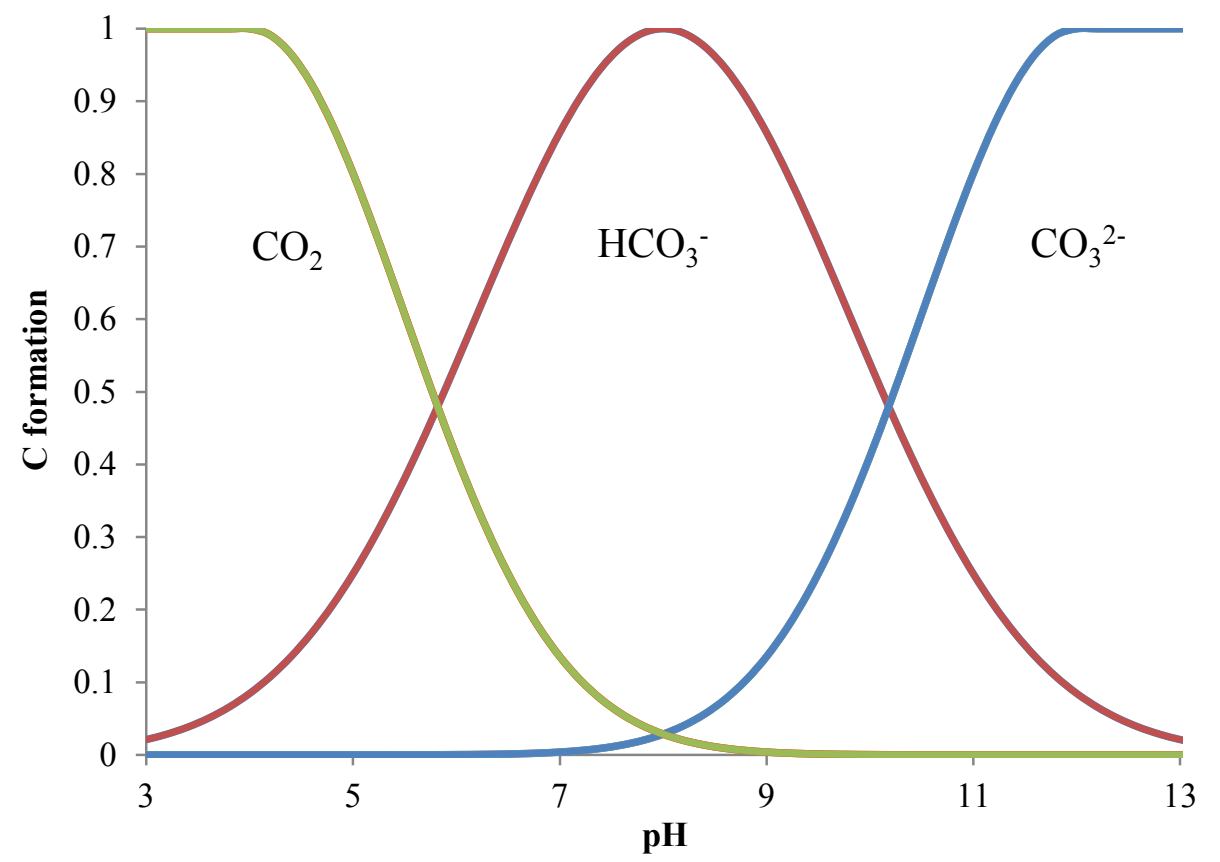

Figure 2.2 Variation of carbon forms in the environment at different $\mathrm{pH}$

After $\mathrm{CO}_{2}$, nitrogen is the second most important element for microalgae growth since it comprises $10 \%$ of microalgae biomass (Becker, 1994). Microalgae can use most forms of nitrogen such as $\mathrm{NH}_{4}^{-}, \mathrm{NO}_{3}{ }^{-}, \mathrm{NO}_{2}{ }^{-}$and $\mathrm{N}_{2}$. However, microalgae would uptake ammonia first until its concentration is depleted, then it would use the other forms. 
Higher concentration of nutrients in wastewater could have a negative effect on microalgae growth, e.g., ammonia concentration more than $20 \mathrm{mg} / \mathrm{l}$ could have a toxic impact on microalgae cell (Borowitzka, 1998).

Phosphorus also is an important nutrient after nitrogen. It is an important nutrient element that comprises $1 \%$ of the cell's dry weight (Brown and Shilton, 2014). In spite of its low percentage, it plays an important role and can inhibit growth when it is limited. Microalgae have an ability to assimilate phosphorus through accumulation and synthesis of polyphosphate in their cell. Polyphosphate can play as phosphorus supplier to prolong algal growth in the absence of phosphorus in wastewater. Thus, the algal growth may not greatly be affected by the changes in the external concentration of phosphorus as it is affected by the change in light and temperature (Fogg, 1975). The most important form of phosphorus for microalgae is orthophosphate $\mathrm{PO}_{4}{ }^{3-}$ that is utilized directly by microalgae. Microalgae cannot take other forms of phosphorus until they are hydrolyzed by extracellular enzymes to $\mathrm{PO}_{4}{ }^{3-}$ (Correll, 1998).

\subsubsection{Effect of $\mathrm{pH}$}

The $\mathrm{pH}$ of the wastewater can influence the metabolism of organisms including microalgae. Every microalgae species has their own optimum range of $\mathrm{pH}$ at which they can function properly. Most microalgae species can ideally grow under neutral $\mathrm{pH}$ or slightly higher. Also, there are some species that prefer acidic conditions. $\mathrm{pH}$ can play an important role in biochemical composition of the wastewater. For instance, Hodaifa et al. (2009) found that $\mathrm{pH}$ has great influence on the growth and biomass composition of microalgae Scenedesmus obliquus. They found that high reduction of $\mathrm{BOD}_{5}$ occurs at 
elevated $\mathrm{pH}$ and the highest protein and chlorophyll content in the cell occur when algae cultivated under $\mathrm{pH}$ of 7.

Some effects of the $\mathrm{pH}$ are listed below:

- It affects the solubility of the oxygen, carbon dioxide, and the mineral salts in the wastewater

- It influences the dissociation and the equilibrium of different ionic species, and it can cause toxic effects, inhibition, or deficiencies in some nutrients in the culture medium (Rubio et al., 1989). High pH level cause precepitation of phosphate in the form of calcium phosphate but it can redissolve when $\mathrm{pH}$ decreases.

- It affects the availability of inorganic carbon in terms of the quantity and proportion of the $\mathrm{CO}_{2}, \mathrm{HCO}_{3}{ }^{-}, \mathrm{CO}_{3}{ }^{2-}$ species in the culture medium (Werner, 1981). As a result, $\mathrm{pH}$ determines which form of inorganic carbon is available for assimilation by microalgae.

Microalgae consume large amounts of $\mathrm{CO}_{2}$ through the photosynthesis process and may deplete it to very low levels. This contributes to an increase in $\mathrm{pH}$ level in the wastewater. Elevated $\mathrm{pH}$ can easily be controlled by bacterial respiration to biodegrade the organic carbon and release $\mathrm{CO}_{2}$ as byproduct that can lower the $\mathrm{pH}$ level in the wastewater. Elevated $\mathrm{pH}$ has some benefits on wastewater treatment such as it can facilitate the flocculation of the biomass and hence improve the harvesting process (Borowitzka, 1998), as well as it can help in disinfection and pathogen kill. 
Increasing $\mathrm{pH}$ represent the indirect role of microalgae to improve the treatment process. High levels of $\mathrm{pH}$ alter the physicochemical environment of the wastewater and cause phosphate and metals precipitation, ammonia stripping and disinfection.

\subsubsection{Effect of grazer organisms and viruses}

In wastewater, there is a complex population of microorganisms that compete with each other for nutrients and survival. Some of the microorganisms have a direct effect on the growth of others, e.g., cyanobacteria can produce inhibitory substances to the growth of eukaryotic algae, also some eukaryotic algae can produce antibacterial substances (Borowitzka, 1998; Fogg, 1975). Microalgae are sensitive and can be affected by many kinds of parasite and viruses present in the wastewater. Due to the high sensitivity of microalgae to ecological changes, they have been used as sensitive indicators in toxicity tests or in studies of microbial ecology (Day et al., 1999).

Microalgae can be infected by different kinds of organisms such as protozoa and unicellular organisms that feed on algae. In using microalgae for wastewater treatment, infection of microalgae is hard to avoid but it is possible to control by maintaining the appropriate environmental and operational conditions for microalgae.

Some of the methods that have been developed to prevent microalgae infection are:

- Acidification of the wastewater to a $\mathrm{pH}$ of 2 for a short period of time, this can help in killing most rotifers and protozoa. 
- Daily removal of particulate matter larger than $100 \mu \mathrm{m}$ (Grobbelaar, 1982) or exposure of wastewater to high concentration of ammonia (Becker, 1994) can help in removing zooplankton.

- Using a system that has short periods of anaerobic stages before microalgae treatment can help to reduce fungal development (Borowitzka, 1998)

\subsection{Microalgae wastewater treatment systems}

Many microalgae based wastewater treatment systems have been used starting from simple stabilization oxidation ponds to more advanced such as HRAPs and activated algae system (concentrated microalgae media system) (McKinney et al., 1971). The most widely used microalgae treatment systems are stabilization ponds and HRAPs. They are open treatment systems that are easy to operate and have low cost. Microalgae have been used in different treatment systems for different wastewater types as indicated in Table 2.4 .

\subsubsection{Wastewater stabilization ponds}

Wastewater is simply treated by biological means for a period of time. It is a shallow pond with no mixing provided. Natural purification steps occur in the stabilization ponds which involve many kinds of organisms working together to uptake pollutants. Aerobic bacteria function near the surface and anaerobic bacteria at the bottom, they breakdown the pollutants into simple compounds then assimilate them and use them as nutrients source for their cell growth. Different kinds of algae are also present in the pond and provide oxygen for aerobic bacteria and uptake $\mathrm{CO}_{2}$ released by bacterial respiration. 
Stabilization ponds are widely used because they are simple in design and operation, economic and achieve a good treatment level. However, stabilization ponds have the disadvantage of having high levels of total suspended solids in the effluent (Bich et al., 1999; Craggs et al., 1997).

\subsubsection{High rate algae ponds (HRAPs)}

HRAPs are wastewater stabilization ponds that involve simple mixing and turbulence within the pond to control the hydraulic flow. HRAPs are raceway ponds with a depth from 0.2 to $1 \mathrm{~m}$. Paddle wheels are commonly used mixing device with a horizontal water velocities around 5-20 $\mathrm{cm} \mathrm{s}^{-1}$. High speed mixing is not recommended as it damages the algal cell (Borowitzka, 1998; Benemann, 1979). Raceway ponds may have a single loop or multible loops around central dividing walls and they may have lined bottoms depending on the soil condition beneath. Heterotrophic bacteria and photosynthetic algae work together in the pond to purify wastewater. $\mathrm{CO}_{2}$ may be added which would also help with mixing in pond.

\subsubsection{Photobioreactors (PBRs)}

A photobioreactor is closed system that is intended to cultivate microalgae for commercial production rather than for treatment purposes. Unlike open systems (e.g. oxidation pond and HRAPs), photobioreactors can be controlled to enhance and increase the algae productivity. Tubular reactors are the most common design and they consist of cylindrical PBRs where gas bubbles are introduced from the bottom of the columns.

Other reactors are flat plate reactors and fermenter-type reactors. Photobioreactors are 
provided with engineered environmental conditions such as gas transfer, mixing, lighting, nutrient level, temperature, and $\mathrm{pH}$ control.

Table 2.4 Different microalgae treatment methods and wastewater types reported in the literature

\begin{tabular}{|c|c|c|c|c|}
\hline Wastewater & Microalgae strain & Reactor setup & Treatment efficiency & References \\
\hline $\begin{array}{l}\text { Domestic } \\
\text { wastewater }\end{array}$ & $\begin{array}{l}\text { Mixed algae } \\
\text { grown naturally } \\
\text { in wastewater }\end{array}$ & $\begin{array}{l}\text { High rate algae ponds, } \mathrm{P} \\
\text { removal and algae } \\
\text { flocculation were } \\
\text { enhanced by adding } \mathrm{CaO} \\
\text { up to } 60 \mathrm{mg} / 1, \mathrm{~T}=10-25^{\circ} \mathrm{C}\end{array}$ & $\begin{array}{l}\text { Removal rate of } 99 \% \\
\mathrm{PO}_{4}^{3-}, 90 \% \mathrm{NH}_{3}-\mathrm{N}, \\
85 \% \mathrm{COD} \text { and algae } \\
\text { removal was } 95 \% \\
\text { after } 24 \mathrm{~h} \text { settling and } \\
60 \% \text { after } 1 \mathrm{hr} \text { settling }\end{array}$ & $\begin{array}{l}\text { (Nurdogan } \\
\text { and Oswald, } \\
\text { 1995) }\end{array}$ \\
\hline $\begin{array}{l}\text { Wastewater } \\
\text { from Steel- } \\
\text { making plant }\end{array}$ & $\begin{array}{l}\text { Chlorella } \\
\text { vulgaris }\end{array}$ & Is not mentioned, $\mathrm{T}=27^{\circ} \mathrm{C}$ & $\begin{array}{l}\text { Removal rate of } 26 \mathrm{~g} \\
\mathrm{CO}_{2} \mathrm{~m}^{-3} \mathrm{~h}^{-1} \text { and } 0.92 \\
\mathrm{~g} \mathrm{NH}_{3} \mathrm{~m}^{-3} \mathrm{~h}^{-1}\end{array}$ & $\begin{array}{l}\text { (Yun et al., } \\
1997 \text { ) }\end{array}$ \\
\hline $\begin{array}{l}\text { Wastewater } \\
\text { from textile } \\
\text { plant }\end{array}$ & $\begin{array}{l}\text { Chlorella } \\
\text { vulgaris }\end{array}$ & $\begin{array}{l}\text { HRAP containing textile } \\
\text { dye, } 10 \text { days, } \mathrm{T}=25^{\circ} \mathrm{C}\end{array}$ & $\begin{array}{l}\text { Removal rate of } \\
44.4-45.1 \% \mathrm{NH}_{4}-\mathrm{N} \text {, } \\
33.1-33.3 \% \mathrm{PO}_{4}-\mathrm{P} \\
\text { and } 38.3-62.3 \% \\
\text { COD }\end{array}$ & $\begin{array}{l}\text { (Lim et al., } \\
\text { 2010) }\end{array}$ \\
\hline $\begin{array}{l}\text { Soybean } \\
\text { processing } \\
\text { wastewater }\end{array}$ & $\begin{array}{l}\text { Chlorella } \\
\text { pyrenoidosa }\end{array}$ & $\begin{array}{l}\text { Batch and fed-batch } \\
\text { cultures, } \mathrm{T}=27^{\circ} \mathrm{C} \pm 1,120 \\
\text { hr. }\end{array}$ & $\begin{array}{l}\text { Removal rate of } 77.8 \\
\pm 5.7 \% \text { sCOD, } 88.8 \\
\pm 1.0 \% \text { TN, } 89.1 \pm \\
0.6 \% \mathrm{NH}_{4}-\mathrm{N} \text { and } \\
70.3 \pm 11.4 \% \text { TP }\end{array}$ & $\begin{array}{l}\text { (Hongyang } \\
\text { et al, 2011) }\end{array}$ \\
\hline $\begin{array}{l}\text { Domestic } \\
\text { wastewater }\end{array}$ & $\begin{array}{l}\text { Wastewater-born } \\
\text { algae }\end{array}$ & $\begin{array}{l}\text { Stirred tank } \\
\text { photobioreactors of } 10 \\
\text { days and } 5: 1 \\
\text { (algae/sludge) mixing } \\
\text { ratio, } \mathrm{T}=23^{\circ} \mathrm{C}\end{array}$ & $\begin{array}{l}\text { Removal rate of } 91.0 \\
\pm 7.0 \% \mathrm{TN} \text { and } 93.5 \\
\pm 2.5 \% \mathrm{TP}\end{array}$ & $\begin{array}{l}\text { (Su et al., } \\
\text { 2012) }\end{array}$ \\
\hline $\begin{array}{l}\text { Piggery } \\
\text { wastewater } \\
\text { effluent }\end{array}$ & $\begin{array}{l}\text { Scenedesmus } \\
\text { obliquus }\end{array}$ & $\begin{array}{l}\text { Batch culture for } 40 \text { days, } \\
\mathrm{T}=25^{\circ} \mathrm{C}\end{array}$ & $\begin{array}{l}\text { Removal of } 155 \mathrm{mg} \\
\text { TN and } 4 \text { mg TP per } \\
\text { gram of dried algae }\end{array}$ & $\begin{array}{l}\text { (Ji et al., } \\
2013)\end{array}$ \\
\hline $\begin{array}{l}\text { Primary and } \\
\text { secondary } \\
\text { domestic } \\
\text { wastewater }\end{array}$ & $\begin{array}{l}\text { Freshwater algal } \\
\text { strain } \\
\text { Desmodesmus } \\
\text { communis }\end{array}$ & $\begin{array}{l}\text { Semi-continuous cultures } \\
\text { were operated for } 7 \text { days } \\
\text { at } 5-, 3 \text { - and } 1.5 \text {-day HRT, } \\
\mathrm{T}=18-25^{\circ} \mathrm{C}\end{array}$ & $\begin{array}{l}\text { Removal of } \mathrm{NH}_{3}-\mathrm{N} \\
\text { and } \mathrm{PO}_{4}-\mathrm{P} \text { was over } \\
99 \%\end{array}$ & $\begin{array}{l}\text { (Samorì et } \\
\text { al., 2014) }\end{array}$ \\
\hline
\end{tabular}




\subsection{Conclusions}

There is an urgent global need to develop new wastewater treatment methods to obtain highly treated effluent with minimal energy consumption. This review chapter presents the science, application and progress over the years on using microalgae in wastewater treatment. Using microalgae in wastewater treatment can greatly improve the treatment process through reducing the pollutant concentrations and aeration requirement. Microalgae can strongly contribute to wastewater treatment process by improving the effluent quality in a sustainable way through their ability to uptake nutrients, COD and $\mathrm{CO}_{2}$ and to inactivate pathogens. Furthermore, due to high concentration of nutrients, final effluent of wastewater can be used as a feedstock to generate high lipid content biomass that can be used for biofuel and biogas generation. As a result, microalgae have the potential to be used at wastewater treatment plants for dual benefits of wastewater treatment and biogas generation in anaerobic digesters. A microalgae based wastewater treatment system should be provided with appropriate environmental and operational conditions such as temperature, light, mixing, etc. Even if these conditions are optimally fulfilled, a number of biological problems may arise during microalgae treatment, such as contamination, grazing, diseases, premature collapse and lack of species control. These problems can be minimized by modifying the operational conditions and controlling the microbial population.

The most costly process in microalgae treatment is the harvesting process. Many harvesting methods have been developed, however, further research should be done to develop harvesting methods that use less energy and chemicals such as developing bioflocculation based processes. Also, an important step forward would be to improve the 
current technology for using a mixed-culture of microalgae and bacteria that have good bioflocculation characteristics. 


\section{Chapter 3 Materials and methods}

\subsection{Microalgae strain}

Microalgae strain used in this study was Chlorella vulgaris. Chlorella vulgaris is a green unicellular organism that obtains food through photosynthesis. They were mentioned in more detail in section 2.3 in the literature review chapter. Chlorella vulgaris was reserved by storing them on agar at $4^{\circ} \mathrm{C}$. The agar was prepared by dissolving $1.5 \mathrm{~g}$ agar (AGR003.500, BioShop) in 100mL Bold's basal medium (BBM) (microalgae culture medium) through autoclaving and $5 \mathrm{~mL}$ agar solution was poured in culture tubes and stored at $4^{\circ} \mathrm{C}$ until using.

\subsection{Microalgae cultivation, monitoring and harvesting}

Microalgae were cultivated in artificial medium in order to help fast and easy growth as well as to maintain an adequate concentration of microalgae biomass that was needed for the experiments. Microalgae strain Chlorella vulgaris was cultivated and maintained in BBM at room temperature in the lab under continuous light provided through cool-white florescent light (two bulbs of 15 watt and length of 24 in). Table 3.1 shows the operational parameters for microalgae cultivation. The cultivation medium was prepared using distilled water and its chemicals composition is described in Table 3.2. The medium was seeded with an initial wet weight of $100 \mathrm{mg}$ microalgae/L collected from the agar. Every 12 days a volume of $100 \mathrm{~mL} / \mathrm{L}$ was taken from the microalgae suspension and replaced with new medium to maintain enough nutrients for the algal biomass. Aeration was provided by diffusing stones placed on the bottom of the cultivation tanks which also achieved mixing. Almost every month a new batch of microalgae cultivation was started. 
The experimental setup is illustrated in Figure 3.1. Some analyses were carried out daily to monitor the microalgae growth conditions which included TS, TVS, ABS, $\mathrm{pH}$ and DO.

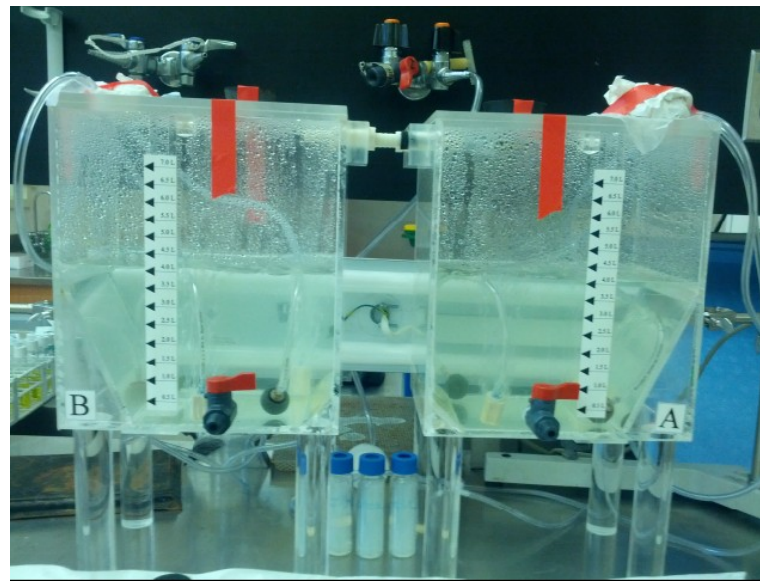

(a)

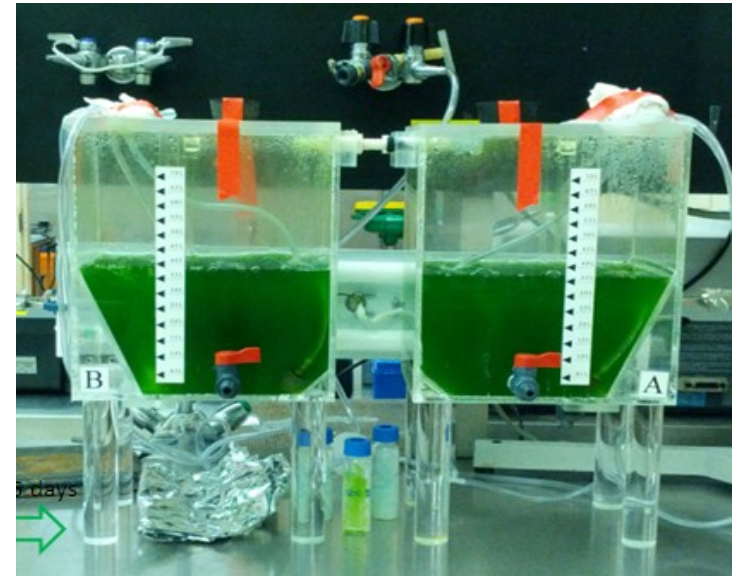

(b)

Figure 3.1 The reactors in which microalgae was cultivated, (a) microalgae suspension on day 1 and (b) microalgae suspension on day 5

\section{Table 3.1 Microalgae cultivation parameters}

\begin{tabular}{|l|l|}
\hline Parameter & Value \\
\hline Light & $1.4-2 \mathrm{~mW} \mathrm{~cm}$ \\
\hline Temperature & $24 \pm 2^{\circ} \mathrm{C}$ \\
\hline Cultivation medium & Bold's Basal Medium \\
\hline
\end{tabular}

Table 3.2 Bold's basal medium chemical composition

\begin{tabular}{|l|l|l|l|l|l|}
\hline Chemical & $\begin{array}{l}\text { Concentration } \\
(\mathrm{mg} / \mathrm{L})\end{array}$ & Chemical & $\begin{array}{l}\text { Concentration } \\
(\mathrm{mg} / \mathrm{L})\end{array}$ & Chemical & $\begin{array}{l}\text { Concentration } \\
(\mathrm{mg} / \mathrm{L})\end{array}$ \\
\hline $\mathrm{K}_{2} \mathrm{HPO}_{4}$ & 75 & $\mathrm{NaCl}$ & 25 & $\mathrm{MnCl}_{2} \cdot 4 \mathrm{H}_{2} \mathrm{O}$ & 0.232 \\
\hline $\mathrm{KH}_{2} \mathrm{PO}_{4}$ & 175 & $\begin{array}{l}\mathrm{EDTA}-\mathrm{Na}_{4} \\
\mathrm{KOH}\end{array}$ & $\begin{array}{l}50 \\
31\end{array}$ & $\mathrm{CuSO}_{4} \cdot 5 \mathrm{H}_{2} \mathrm{O}$ & 0.252 \\
\hline $\mathrm{MgSO}_{4} \cdot 7 \mathrm{H}_{2} \mathrm{O}$ & 75 & $\begin{array}{l}\mathrm{FeSO}_{4} 7 \mathrm{H}_{2} \mathrm{O} \\
\mathrm{H}_{2} \mathrm{SO}_{4}\end{array}$ & $\begin{array}{l}4.98 \\
0.001 \mathrm{ml}\end{array}$ & $\mathrm{Co}_{\left(\mathrm{NO}_{3}\right)_{2} \cdot 6 \mathrm{H}_{2} \mathrm{O}} 0.08$ \\
\hline $\mathrm{NaNO}_{3}$ & 250 & $\mathrm{H}_{3} \mathrm{BO}_{3}$ & 11.42 & $\mathrm{Na}_{2} \mathrm{MoO}_{4} \cdot 2 \mathrm{H}_{2} \mathrm{O}$ & 0.912 \\
\hline $\mathrm{CaCl}_{2} \cdot 2 \mathrm{H}_{2} \mathrm{O}$ & 25 & $\mathrm{ZnSO}_{4} \cdot 7 \mathrm{H}_{2} \mathrm{O}$ & 1.412 & & \\
\hline
\end{tabular}


Microalgae growth and biomass concentration were monitored by taking samples from the algae suspension daily for the measurements of three parameters; TS, TVS and ABS of the samples at $680 \mathrm{~nm}$ using a spectrophotometer (100 Bio UV-visible spectrophotometer). In addition, $\mathrm{pH}$ and $\mathrm{DO}$ were measured daily to monitor the growth conditions.

Several sets of preliminary experiments were carried out to establish the growth and cultivation patterns of microalgae and to understand the impact of the experimental conditions such as $\mathrm{pH}$ and $\mathrm{DO}$. The data from these experiments are presented in Appendix A, which helped to design the experimental work presented in Chapters 4 and 5.

Microalgae samples were harvested after 7 to 10 days of cultivation. When microalgae growth reached between 1500 to $2000 \mathrm{mg} \mathrm{TS} / \mathrm{L}$, microalgae samples were transferred to $200 \mathrm{~mL}$ centrifuge bottles. They were centrifuged at $3000 \mathrm{rpm}, 20^{\circ} \mathrm{C}$ for $15 \mathrm{~min}$. The supernatant was removed and the pellet was washed with distilled water three times to remove salt residues. Then, the wet biomass was used in the wastewater treatment tests at the selected concentrations by suspending them in the wastewater samples.

\subsection{Wastewater samples}

Wastewater samples were collected from the ROPEC wastewater treatment plant (Ottawa, ON). There were four different types of samples used in this study. These were secondary effluent before disinfection, centrate of the anaerobically digested sludge after dewatering, primary effluent and return activated sludge. Secondary effluent was collected from the secondary clarifier. Centrate was collected from the liquid line that 
came out of the centrifuge. Primary effluent was collected from the primary clarifiers. Return activated sludge was taken from the line that returns the activated sludge to the aeration tank. The characteristics of the samples are illustrated in Table 3.3.

Table 3.3 Samples characteristics

\begin{tabular}{|c|c|c|c|c|c|c|c|c|}
\hline Sample & $\begin{array}{c}\mathrm{sCOD} \\
(\mathrm{mg} / \mathrm{L})\end{array}$ & $\begin{array}{c}\mathrm{TN} \\
(\mathrm{mg} / \mathrm{L})\end{array}$ & $\begin{array}{c}\mathrm{NH}_{3}-\mathrm{N} \\
(\mathrm{mg} / \mathrm{L})\end{array}$ & $\begin{array}{c}\mathrm{NO}_{3}-\mathrm{N} \\
(\mathrm{mg} / \mathrm{L})\end{array}$ & $\begin{array}{c}\mathrm{P} \\
(\mathrm{mg} / \mathrm{L})\end{array}$ & $\mathrm{pH}$ & $\begin{array}{c}\mathrm{TS} \\
(\mathrm{mg} / \mathrm{L})\end{array}$ & $\begin{array}{c}\mathrm{TVS} \\
(\mathrm{mg} / \mathrm{L})\end{array}$ \\
\hline $\begin{array}{c}\text { Secondary } \\
\text { effluent }\end{array}$ & 45 & 50 & - & - & 3 & 7.32 & 583.5 & 177.5 \\
\hline Centrate & 1348 & 830 & - & - & 23 & 7.83 & 1597 & 828 \\
\hline $\begin{array}{c}\text { Primary } \\
\text { effluent }\end{array}$ & 65 & - & 26 & 0.4 & 4 & 7.5 & 853.5 & 263.5 \\
\hline
\end{tabular}

Secondary effluent is a relatively clear liquid, it has less solids compared to primary effluent and centrate, and has more pathogens compared to centrate. Centrate has high solids content and hence high turbidity. It has lower pathogen content compared to secondary and primary effluent. Centrate also has high concentrations of N, P and COD making it an excellent medium for microalgae cultivation. Primary effluent has very high pathogen content and solids concentration compared to secondary effluent. To simulate realistic conditions, wastewater samples were used directly in the experiments without filtration, autoclaving, or additional processes. Also, there was no nutrient addition to wastewater samples.

\subsection{Experimental design}

All the experiments in this study were conducted in batch scale reactors under wellknown conditions. In all experiments, the reactors were incubated at room temperature $\left(24 \pm 2^{\circ} \mathrm{C}\right)$ in the lab. The reactors were provided with continuous light through 
florescent cool white light, (two bulbs of 15 watt and 24 in.) at $10 \mathrm{~cm}$ behind the reactor, with an intensity of $1.4-2 \mathrm{~mW} \mathrm{~cm}^{-2}$. Also, an equal and constant aeration rate was provided for all samples and reactors through flowmeters. Aeration was achieved by air bubbling provided by aeration stones placed on the bottom of the Erlenmeyer flasks. Liquid samples were taken daily for direct analyses of the concentration of soluble COD, dissolved total $\mathrm{P}$, and dissolved TN, $\mathrm{NH}_{3}-\mathrm{N}$ and $\mathrm{NO}_{3}-\mathrm{N}$. Also, TC, TS, TVS, $\mathrm{pH}, \mathrm{ABS}$ and DO were measured daily according to the purpose of the experiment. The temperature was measured by a thermometer (FISHER brand, $78 \mathrm{~mm}$ ). The experimental periods were between 5 to 7 days and each test sample had three replicates. Wastewater and microalgae culture was maintained in suspension by providing a continuous mixing of $100 \mathrm{rpm}$ using a magnetic stirrer. The effect of the evaporation was taken into consideration by calculating the daily amount of wastewater that was lost. The experiments were completed without the addition of any chemicals or adjustment of environmental conditions. Wastewater in the reactor was seeded with known initial concentrations of microalgae according to the purpose of the experiment.

\subsection{Chemical analyses}

Chemicals in wastewater were analyzed using the methods provided in the HACH DR 2800 Spectrophotometer Manual (HACH, 2007). In general, chemicals were measured by taking liquid samples from the reactor using a pipette every day during the experiment period. The samples were centrifuged for $15 \mathrm{~min}$ at $20^{\circ} \mathrm{C}$ and the supernatant was filtered through a $0.45 \mu \mathrm{m}$ syringe filter (mixed cellulose ester syringe filter, Glassco Laboratory Equipment). After filtration, samples were immediately analyzed for measuring soluble COD, dissolved total $\mathrm{P}$, and dissolved $\mathrm{TN}, \mathrm{NH}_{3}-\mathrm{N}$ and $\mathrm{NO}_{3}-\mathrm{N}$. 


\subsubsection{Chemical oxygen demand (COD)}

COD was analyzed according to HACH Method 8000 (HACH, 2007). It was analyzed by heating the sample for two hours with sulfuric acid and a strong oxidizing agent, potassium dichromate. All oxidizable organic compounds react and reduce the

dichromate ion $\left(\mathrm{Cr}_{2} \mathrm{O}_{7}^{2-}\right)$ to green ion $\left(\mathrm{Cr}^{3+}\right)$. When the low concentration range is used (3-150mg/L), the amount of $\mathrm{Cr}^{6+}$ remaining is determined. On the other hand, when high concentration range is used $(20-1500 \mathrm{mg} / \mathrm{L})$, the amount of $\mathrm{Cr}^{6+}$ produced is determined. $\mathrm{COD}$ is measured at wavelength of $420 \mathrm{~nm}$ for low range and at $620 \mathrm{~nm}$ for high range.

\subsubsection{Ammonia-nitrogen $\left(\mathrm{NH}_{3}-\mathrm{N}\right)$}

Ammonia-nitrogen was analyzed according to $\mathrm{HACH}$ Method 10031 (HACH, 2007). It was measured using salicylate method and a HACH DR 2800 spectrophotometer. According to this method, ammonia compounds combine with chlorine to form monochloramine that reacts with salicylate to form 5-aminosalicylate. Then, the 5aminosalicylate is oxidized in the presence of a sodium nitroprusside catalyst to form a blue-colored compound. The blue color is masked by the yellow color from the excess reagent present to give a green-colored solution.

\subsubsection{Nitrate $\left(\mathrm{NO}_{3}-\mathrm{N}\right)$}

Nitrate-nitrogen was analyzed according to HACH Method 10020 (HACH, 2007). It was analyzed using chromotropic acid method and a HACH DR 2800 spectrophotometer. According to this method, nitrate reacts with chromotropic acid under strongly acidic conditions to yield a yellow product with a maximum absorbance at $410 \mathrm{~nm}$. 


\subsubsection{Total nitrogen $(\mathrm{TN})$}

Total nitrogen was analyzed according to $\mathrm{HACH}$ Method $10072(\mathrm{HACH}, 2007)$. persulfate digestion method and a HACH DR 2800 spectrophotometer were used to measure TN in the sample. All forms of nitrogen in the sample will be converted to nitrate by alkaline persulfate digestion according to this method. Nitrate reacts with chromotropic acid under strong acidic conditions to form a yellow complex with an absorbance maximum near $420 \mathrm{~nm}$.

\subsubsection{Phosphorus $(\mathrm{P})$}

Phosphorus was analyzed according to HACH Method 10127 (HACH, 2007). It was analyzed using molybdovanadate method with acid persulfate digestion and a HACH DR 2800 spectrophotometer. According to this method, organic and condensed phosphates are converted to reactive orthophosphate by heating with acid and persulfate. The measurement wavelength is $880 \mathrm{~nm}$.

\subsection{Total coliform analysis}

Total coliform (TC) was analyzed via standard plate count procedure using m-Endo (Difco m-Endo Agar LES) agar according to part 9222, Standard Method (Eaton et al., 2005). Samples were analyzed for TC after applying MF method using $0.45 \mu \mathrm{m}$ pore-size mixed cellulose esters filter. Total coliform colonies were counted after $24 \mathrm{~h}$ incubation period at $35^{\circ} \mathrm{C}$, and coliform forming units (CFU) were calculated according to the following formula (Eaton et al., 2005): 


$$
\mathrm{CFU} / \mathrm{mL}=\frac{\text { colonies counted }}{\text { actual volume of sample in the dish, } \mathrm{mL}}
$$

\subsubsection{Preparation of the agar plates}

Agar plates were prepared by suspending 51g m-Endo agar (Difco m-Endo Agar LES) in $1 \mathrm{~L}$ water containing $20 \mathrm{~mL} 95 \%$ ethanol and heating to near boiling. Then it was allowed to cool down to $50^{\circ} \mathrm{C}$ and $5-7 \mathrm{ml}$ aliquots were dispensed into sterile $60 \mathrm{~mm}$ plastic petri dishes. These plates were stored in the dark in the refrigerator.

\subsubsection{Dilution water}

Samples were diluted with PBS before filtration in order to obtain countable colonies after incubation. Dilution water was prepared by adding $1.25 \mathrm{~mL}$ stock phosphate buffer solution and $5 \mathrm{~mL}$ magnesium chloride solution to $1 \mathrm{~L}$ deionized water. Stock phosphate buffer solution was prepared by dissolving $34.0 \mathrm{~g}$ potassium dihydrogen phosphate $\left(\mathrm{KH}_{2} \mathrm{PO}_{4}\right)$ in $500 \mathrm{~mL}$ deionized water and the $\mathrm{pH}$ of the solution was adjusted to $7.2 \pm 0.5$ with $1 \mathrm{~N}$ sodium hydroxide $(\mathrm{NaOH})$ and the volume of the solution was completed to $1 \mathrm{~L}$. Magnesium chloride solution was prepared by dissolving $81.1 \mathrm{~g} \mathrm{MgCl}_{2} \cdot 6 \mathrm{H}_{2} \mathrm{O}$ in $1 \mathrm{~L}$ deionized water.

\subsubsection{Membrane filtration (MF) procedure}

Wastewater samples were analyzed daily for TC using MF method. A known volume of sample was diluted with PBS as needed and filtered through a $0.45 \mu \mathrm{m}$ membrane filter. The membrane filter was placed top side up on the m-Endo agar in the plates and 
incubated at $35^{\circ} \mathrm{C}$ for $24 \mathrm{~h}$. The colonies that were red and had a metallic sheen were enumerated and reported.

\subsection{Total solids and total volatile solid analysis}

TS and TVS were measured according to part 2540, Standard Method (Eaton et al., 2005). TS were determined by drying $5 \mathrm{~mL}$ microalgae-wastewater suspension in the oven at $105^{\circ} \mathrm{C}$ for $24 \mathrm{~h}$. The difference in the weight of the sample before and after drying was the TS per sample volume. TVS was determined by burning the TS in the furnace at $550^{\circ} \mathrm{C}$ for $30 \mathrm{~min}$ and TVS was calculated from the difference between the TS before and after the furnace. In microalgae studies, TS and TVS are commonly used for quantification of total solids and microalgae biomass in samples since dissolved solids is not considered significant compared to the high concentrations of suspended microalgae biomass and also due to the difficulty of filtering microalgae grown samples required for the total suspended solids analyses.

\subsection{Absorbance, dissolved oxygen and $\mathrm{pH}$ analyses}

The ABS of microalgae-wastewater suspension was measured at wavelength of $680 \mathrm{~nm}$ against distilled water blank using a spectrophotometer (100 Bio UV-visible spectrophotometer). The absorbance was used to calculate the growth rate of microalgae according to the following equation:

$$
\text { Growth rate }(\mathrm{GR})=\frac{(\ln A B S(t)-\ln A B S(0))}{t}
$$

Where ABS $(t)$ is the absorbance measured at time $t$. 
Also, to monitor the treatment condition, $\mathrm{DO}$ and $\mathrm{pH}$ were daily measured by using Orion-thermo scientific device (Orion Star ${ }^{\mathrm{TM}}$ A326 pH/DO Portable Meter).

3.9 Capillary suction time analysis

Capillary suction time (CST) was measured for the samples at the end of the experiments by using Triton Electronics type 31, Multi-CST device. CST was measured for each sample in three replicates.

\subsection{Settling performance}

At end of the experiments, settling performance of each sample was assessed by doing simple gravity sedimentation test using $100 \mathrm{~mL}$-cylinders. Sludge settling was monitored every $10 \mathrm{~min}$ in for $30 \mathrm{~min}$ settling period. The gravity settling experiments were repeated three times and average values were reported. Also, absorbance and turbidity of supernatant were measured after the settling period. Turbidity was measured using a HACH 2100AN turbidimeter. 


\section{Chapter 4 Phase 1: Using microalgae for treatment of secondary effluent and centrate}

\subsection{Introduction}

In Phase 1, the potential use of microalgae for tertiary wastewater treatment and treatment of side streams was studied. Secondary effluent and centrate were treated with microalgae for 7 days and the treatment performance was evaluated through daily measurement of sCOD, nitrogen, phosphorus and coliform bacteria in samples. In this phase, microalgae treatment was envisioned as a separate and additional treatment process that can be incorporated in treatment plants without significantly changing the treatment train or increasing the complexity of the treatment. Also, in order to keep the system simple, wastewater was used as is and no heating or $\mathrm{CO}_{2}$ addition was provided to optimize the microalgae growth.

\subsection{Materials and methods}

\subsubsection{Wastewater samples}

Wastewater samples were taken from ROPEC wastewater treatment plant (Ottawa, ON). The samples were secondary effluent and centrate. Secondary effluent samples were collected before disinfection and centrate samples were collected after centrifugation of anaerobically digested sludge. In this study, wastewater samples were used directly after collection without filtration, autoclaving or other pretreatment. Also, there was no heating, $\mathrm{CO}_{2}$ or nutrients addition to wastewater samples in order to observe the performance of microalgae in a simple configuration that does not increase the 
complexity or cost of treatment. The characteristics of the collected secondary effluent and centrate samples are shown in Table 4.1.

Table 4.1 Secondary effluent and centrate properties

\begin{tabular}{|l|c|c|c|c|c|c|c|}
\hline Properties & $\begin{array}{c}\text { sCOD } \\
(\mathrm{mg} / \mathrm{L})\end{array}$ & $\begin{array}{c}\mathrm{TN} \\
(\mathrm{mg} / \mathrm{L})\end{array}$ & $\begin{array}{c}\mathrm{P} \\
(\mathrm{mg} / \mathrm{L})\end{array}$ & $\mathrm{pH}$ & $\begin{array}{c}\mathrm{TS} \\
(\mathrm{mg} / \mathrm{L})\end{array}$ & $\begin{array}{c}\mathrm{TVS} \\
(\mathrm{mg} / \mathrm{L})\end{array}$ & $\begin{array}{c}\mathrm{TC} \\
(\mathrm{CFU} / \mathrm{mL})\end{array}$ \\
\hline $\begin{array}{l}\text { Secondary } \\
\text { effluent }\end{array}$ & 45 & 50 & 3 & 7.32 & 583.5 & 177.5 & $87 \times 10^{2}$ \\
\hline Centrate & 1348 & 830 & 23 & 7.83 & 1597 & 828 & $9 \times 10^{2}$ \\
\hline
\end{tabular}

\subsubsection{Microalgae}

Microalgae strain used in this study was Chlorella vulgaris. It was described in more detail in Section 2.3.1. Chlorella vulgaris was cultivated and maintained in BBM. After the growth of microalgae, the cultivation medium was removed by centrifugation and washed off from the microalgae biomass with distilled water. This biomass was then added to the wastewater samples to give the desired microalgae concentrations after resuspension in the sample itself.

\subsubsection{Experimental design}

Batch reactor experiments were conducted in $2 \mathrm{~L}$ sterilized Erlenmeyer glass flasks shown in Figure 4.1. Each flask had a sample volume of 1 L. The Erlenmeyer flasks were incubated at room temperature of $24 \pm 2^{\circ} \mathrm{C}$ in the lab. Continuous florescent cool white light (two bulbs of 15 watt and 24 in.) was provided for the reactors at an intensity of 1.4$2 \mathrm{~mW} \mathrm{~cm}^{-2}$ and at a distance of $10 \mathrm{~cm}$ behind the flasks. Samples were taken daily for analyses of soluble or dissolved concentrations of COD, P and TN. Also, TC, TS, TVS, 
$\mathrm{pH}, \mathrm{ABS}$ and DO were measured daily. The temperature was monitored by a thermometer (FISHER brand, $78 \mathrm{~mm}$ ). The experimental period was 7 days. All measurements had three replicates, and the average values with the standard deviations are reported in the figures. Wastewater and microalgae culture was maintained in suspension by using a magnetic stirrer at $100 \mathrm{rpm}$. Equal and constant aeration rates were provided to both reactors using flowmeters. Aeration was achieved through air bubbling provided by aeration stones placed on the bottom of the Erlenmeyer flasks. The flasks were covered with aluminum foil to minimize evaporation, and the effect of the evaporation that still occurred was taken into consideration by calculating the daily amount of sample that was lost. Experiments were carried out without the addition of nutrients or any chemicals for $\mathrm{pH}$ adjustment. Both secondary effluent and centrate were seeded with start-up concentrations of $1,500 \mathrm{mg}$ TVS microalgae/L.

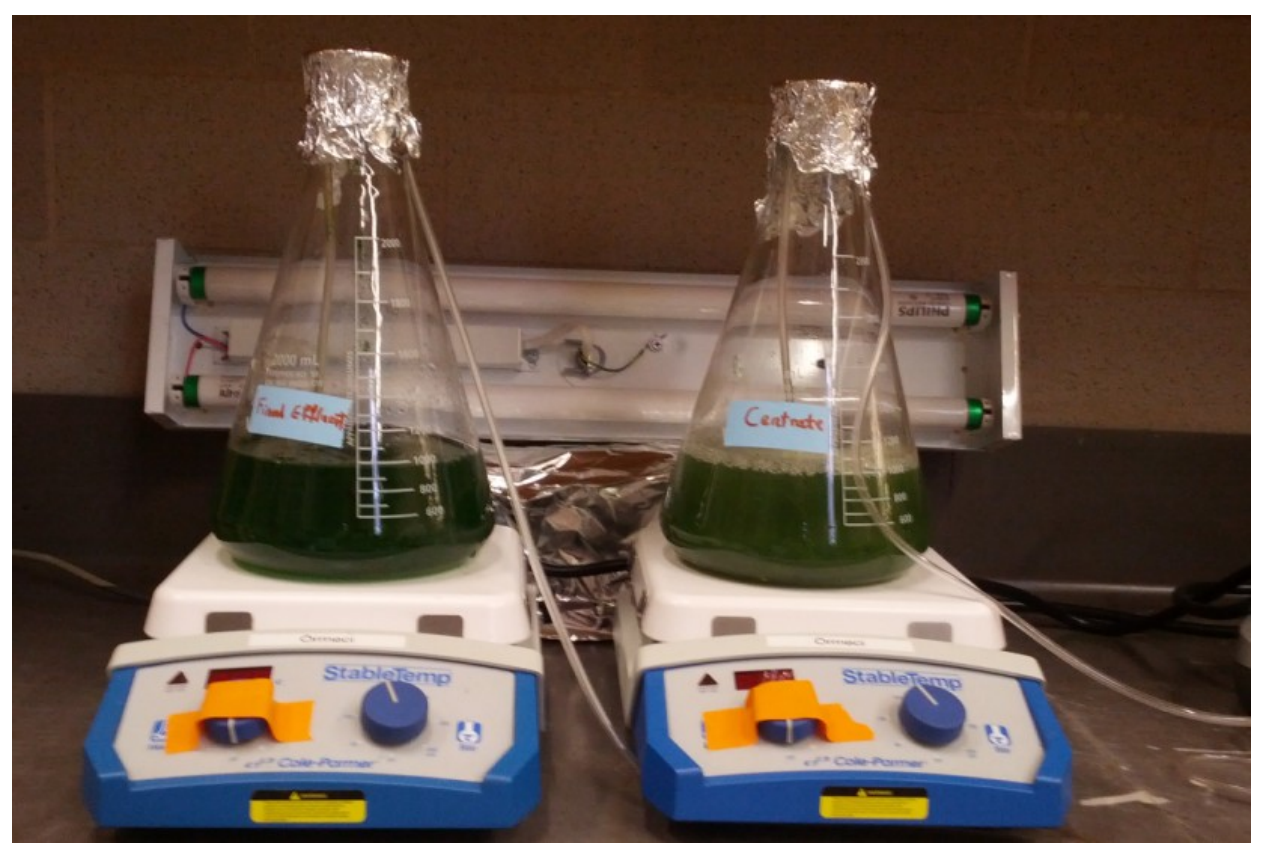

Figure 4.1 Microalgae reactor for secondary effluent and centrate 


\subsubsection{Chemical analyses}

Wastewater characteristics were analyzed every day after taking liquid samples from the reactors using a pipette during the experiment period. The collected samples were centrifuged for $15 \mathrm{~min}$ at $20^{\circ} \mathrm{C}$ and the supernatant was filtered through a $0.45 \mu \mathrm{m}$ syringe filter (mixed cellulose ester syringe filter, Glassco Laboratory Equipment). After filtration, supernatant samples were immediately analyzed for COD, TN and P according to methods.

\subsubsection{Total coliform analysis}

TC was used as indicator organism for pathogens. Samples were daily taken from the reactor for the analyses. TC colonies were enumerated by standard plate count procedure using m-Endo Agar (Difco m-Endo Agar LES) for culture media after applying the membrane filtration method (part 9222 from Standard Methods) (Eaton et al., 2005). Samples were cultured at different dilutions with three replicates for each dilution. PBS was used as the dilution media. Each dilution was filtered through $0.45 \mu \mathrm{m}$ pore-size mixed cellulose esters filter. Then, the filter was cultivated on m-Endo Agar in petri dishes and the plates were incubated at $35^{\circ} \mathrm{C}$ for $24 \mathrm{~h}$ in the incubator. The decrease in the number of TC colonies was used to assess the level of disinfection attributed to microalgae treatment. TC die-off was calculated by measuring the daily decrease in the total coliform colonies during the experimental period. The MF method and the composition of the PBS are performed according to standard methods (Eaton et al., 2005). 


\subsection{Results and discussion}

\subsubsection{Microalgae growth}

Microalgae growth was monitored by taking three daily measurements: TS, TVS and ABS. Figures 4.2 and 4.3 illustrate the microalgae growth development in terms of TS, TVS and ABS for both secondary effluent and centrate, respectively.

For secondary effluent, TS and TVS follow the same pattern. The lag phase lasted for two days in which microalgae growth was very slow due to the new environmental conditions to which microalgae had to adapt. After that, microalgae biomass started to increase until the fifth day of incubation when the growth started to be in a stationary phase. The difference between TS and TVS almost remained the same.

When $\mathrm{ABS}$ was used to monitor the microalgae growth rate, a rapid increase could be seen from the beginning of the experiment. In terms of absorbance, the mean growth rate for the first 4 days was $0.26 \mathrm{~d}^{-1}$ while the mean growth rate after the lag phase was $0.27 \mathrm{~d}^{-}$

${ }^{1}$. These values were lower than the growth rate of $0.91 \mathrm{~d}^{-1}$ when microalgae were grown in BBM (Appendix A). Even though wastewater provides a good medium, it is not the optimal medium and there is competition from other microorganisms. 


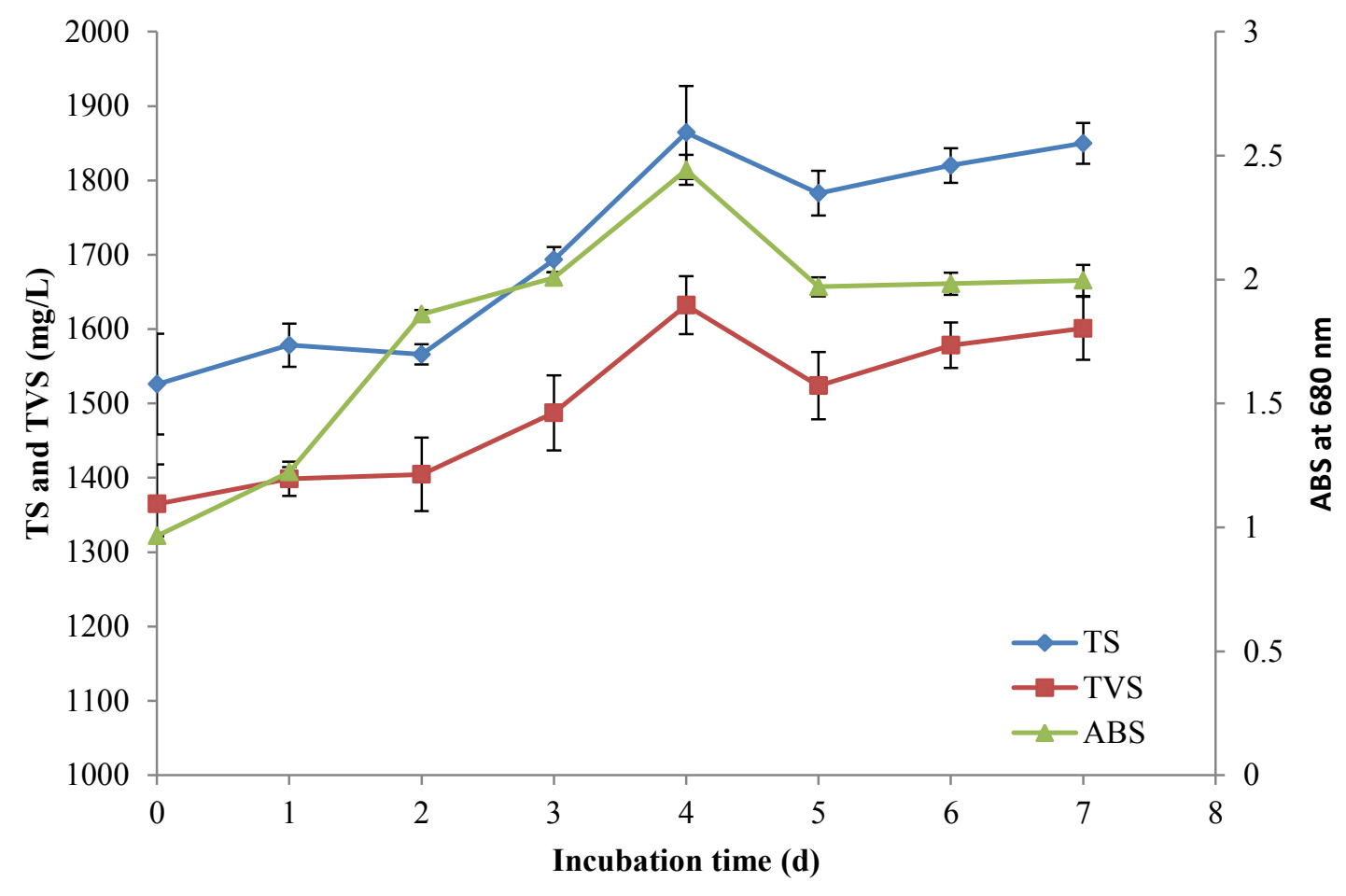

Figure 4.2 Microalgae growth in secondary effluent

For centrate, TS and TVS also showed a steady increase during the experimental period (Figure 4.3). There was 2 days of lag phase followed by a rapid phase of microalgae growth. Then, the growth started to stabilize at day 5 and remained the same after that. A similar pattern was observed for the ABS as well but with a sharper increase on days 3 and 4 . The average growth rate for the microalgae in centrate during the first 4 days was $0.06 \mathrm{~d}^{-1}$ while the mean growth rate during the exponential phase was $0.07 \mathrm{~d}^{-1,}$ which were lower than the average growth rates for the secondary effluent. In both secondary effluent and centrate, the increase in TVS was slightly less than that for TS. 


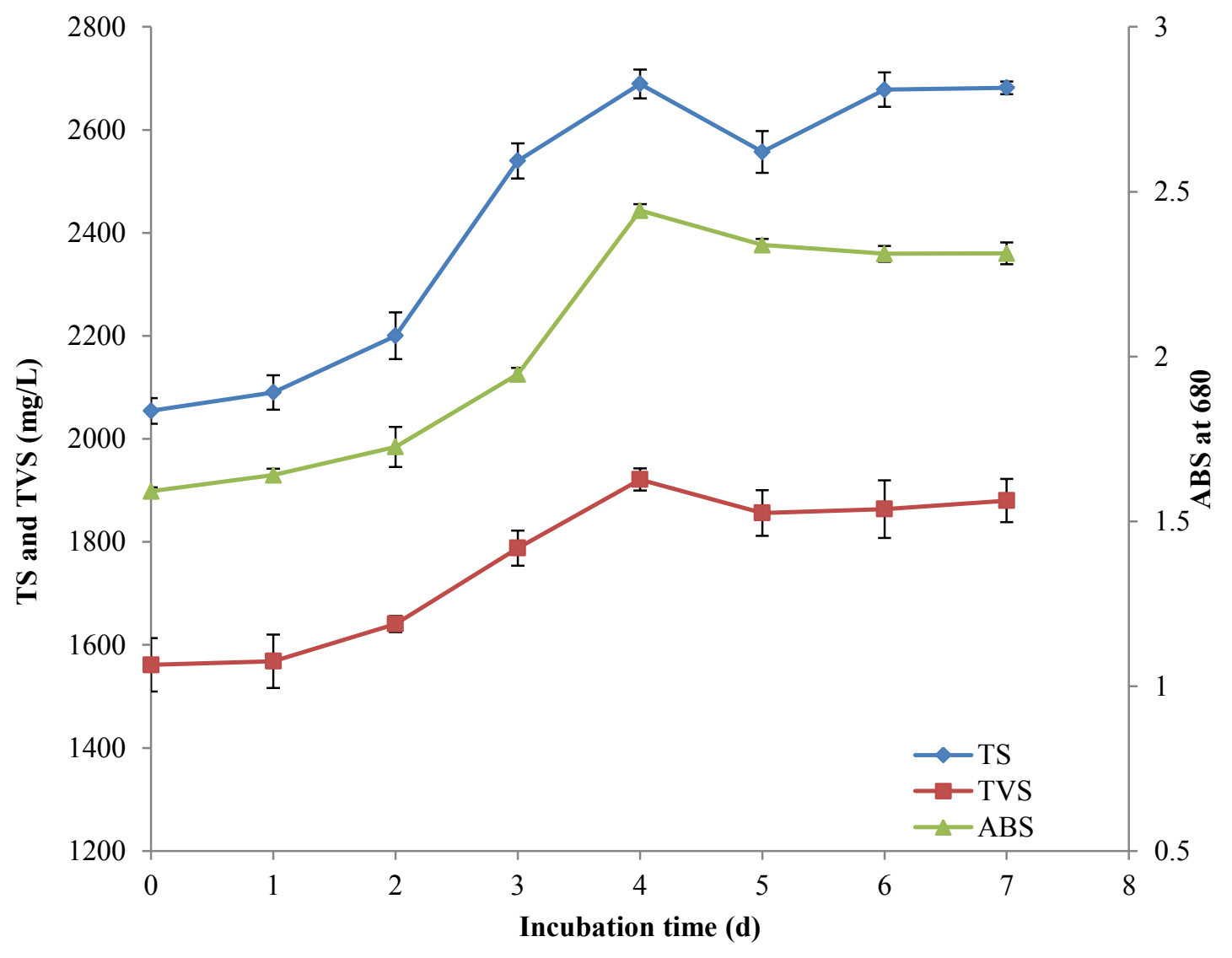

Figure 4.3 Microalgae growth in centrate

\subsubsection{Change in $\mathrm{pH}$}

Microalgae growth caused $\mathrm{pH}$ levels to increase during the experimental period due to the photoautotrophic growth; $\mathrm{pH}$ increases due to $\mathrm{CO}_{2}$ assimilation by microalgae (Borowitzka, 1998). Figure 4.4 illustrates the daily changes in $\mathrm{pH}$ levels for the secondary effluent and centrate. $\mathrm{pH}$ levels increased from 7.33 to 7.67 for secondary effluent and from 7.65 to 8.12 for the centrate during the 7 days of the experiment. Elevated $\mathrm{pH}$ has many impacts on wastewater treatment. It causes phosphorus precipitation through the formation of hydroxyapatite (Diamadopoulos and Benedek, 1984), helps to improve flocculation of particles and also disinfect pathogenic organisms as well. 


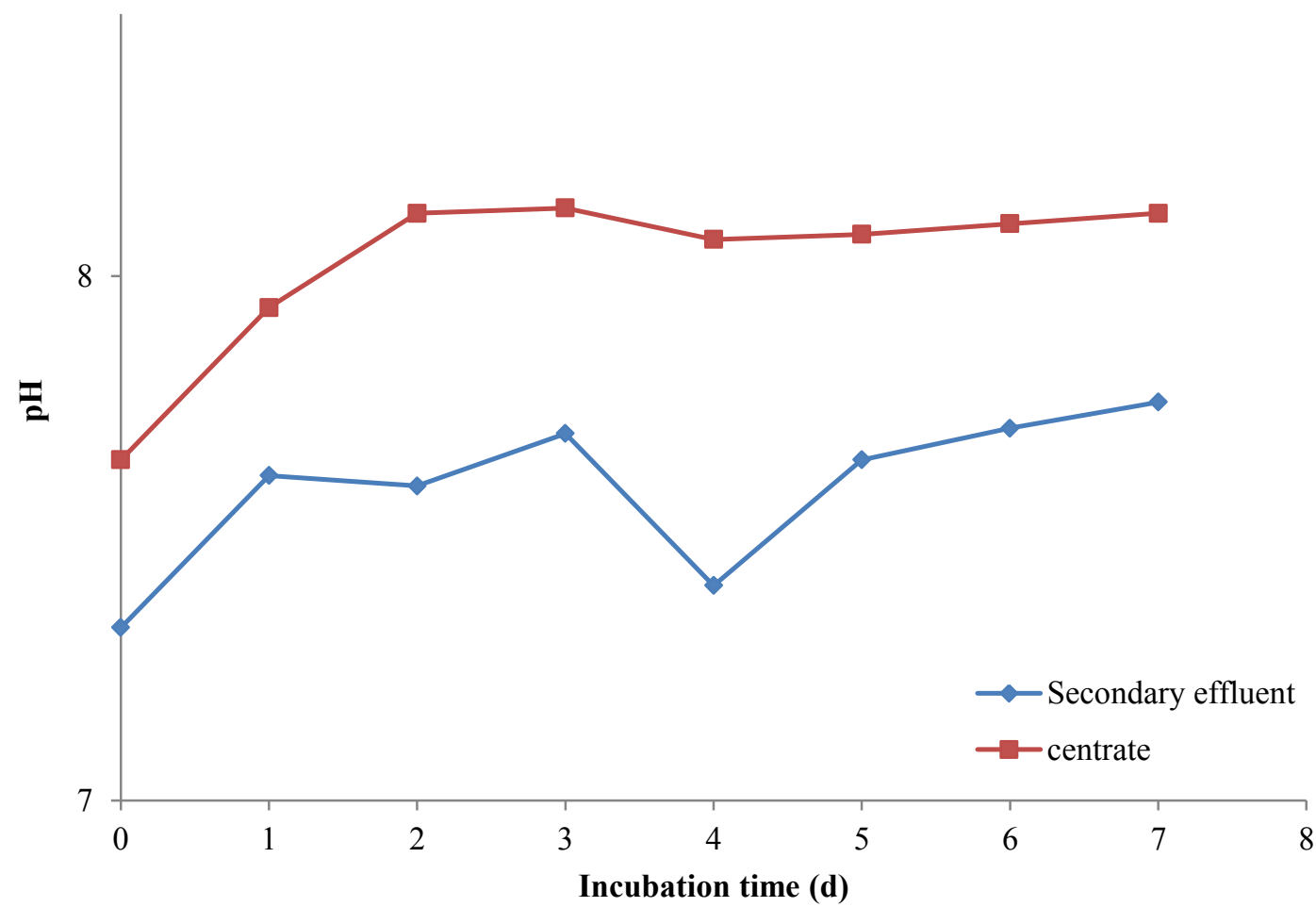

Figure 4.4 pH change during the experiment

\subsubsection{Removal of dissolved total nitrogen}

Nitrogen is an essential nutrient required by microalgae cells. Microalgae have the ability to uptake nitrogen particularly in the inorganic nitrogen form. The changes in the dissolved TN concentration for both the secondary effluent and centrate are described in Figure 4.5. TN concentration decreased starting from the first day until the end of the experiment period for both secondary effluent and centrate. There was some fluctuation in nitrogen removal for the secondary effluent and the decrease in nitrogen was linear for the centrate. The increase that was observed in nitrogen on days 5 and 6 for secondary effluent may be due to die-off and decomposition of some of the bacteria and microalgae since no additional nutrient and carbon source was provided during the experiments. 
$\mathrm{TN}$ reduction for the secondary effluent and centrate after 7 days was 27 and $49.4 \%$, respectively. TN reduction was higher in centrate than secondary effluent which indicated that centrate provided better growth conditions for Chlorella compared to the secondary effluent. TN was likely mainly removed through assimilation by microalgae and other organisms. However, part of the TN may be removed through volatilization due to elevated $\mathrm{pH}$ levels occurred as a result of microalgae activity. Regardless, the reduction in total nitrogen for both the secondary effluent and centrate can be very beneficial for the treatment process.

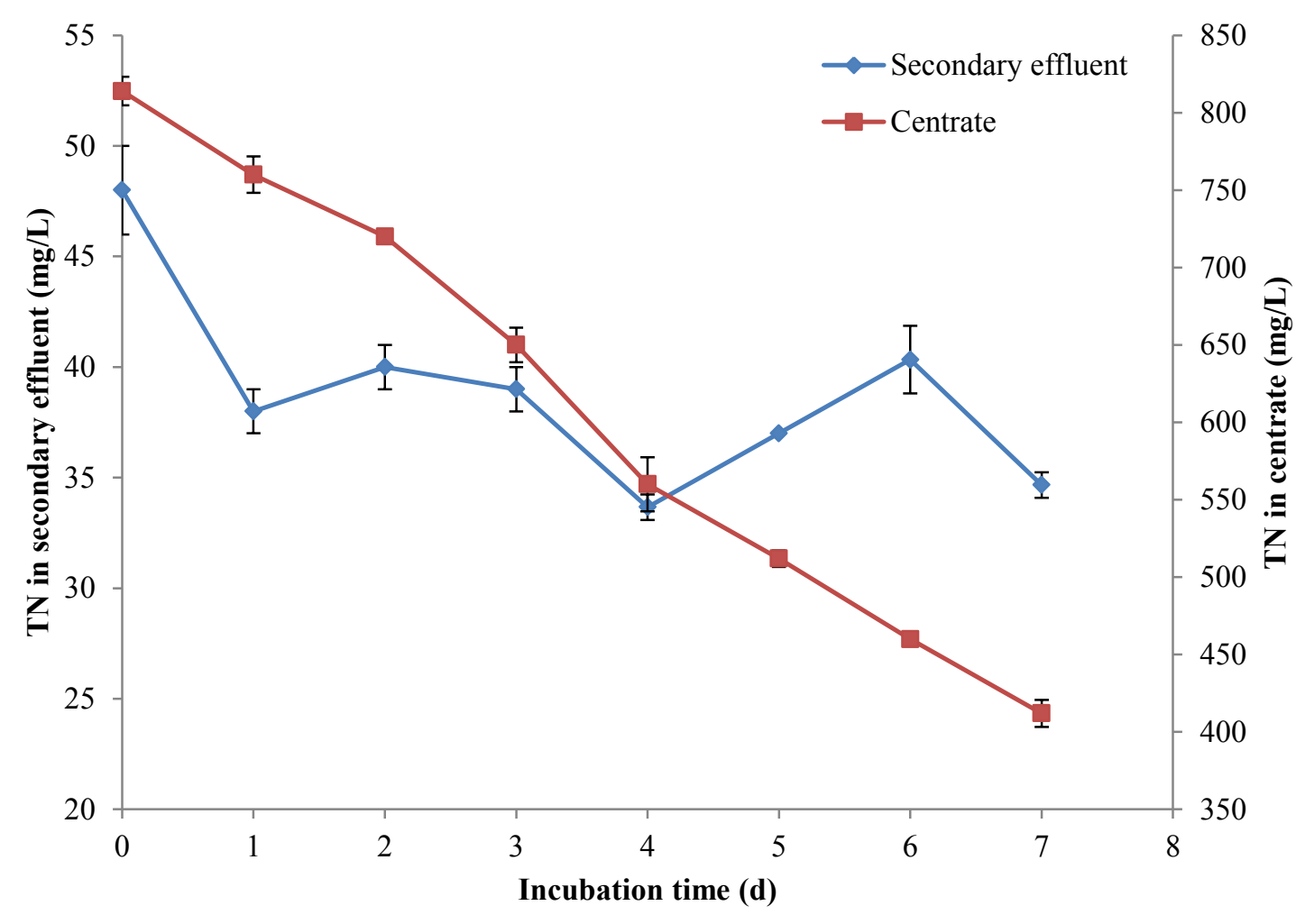

Figure 4.5 Dissolved total nitrogen concentration in secondary effluent and centrate during the experiment 


\subsubsection{Removal of dissolved phosphorus}

Phosphorus is an essential nutrient for the growth of microalgae. It is taken up by microalgae in inorganic form. P removal achieved during the experiments is illustrated in Figure 4.6. Dissolved phosphorus was efficiently reduced for both the secondary effluent and centrate by 51.7 and $78.6 \%$, respectively. Similar to the results observed with nitrogen, the uptake of phosphorus from centrate was higher than the uptake from the secondary effluent. The most important form of phosphorus for microalgae is orthophosphate $\mathrm{PO}_{4}{ }^{3-}$ which is utilized directly by microalgae. Microalgae cannot utilize other forms of phosphorus until they are hydrolyzed by extracellular enzymes to $\mathrm{PO}_{4}{ }^{3-}$ (Correll, 1998). High level of $\mathrm{pH}$ associated with microalgae treatment can result in phosphorus precipitation. Thus, phosphorus can be removed not only due to microalgae uptake but also due to precipitation. The results also showed that the percent removal of phosphorus was higher than the percent removal of nitrogen. 


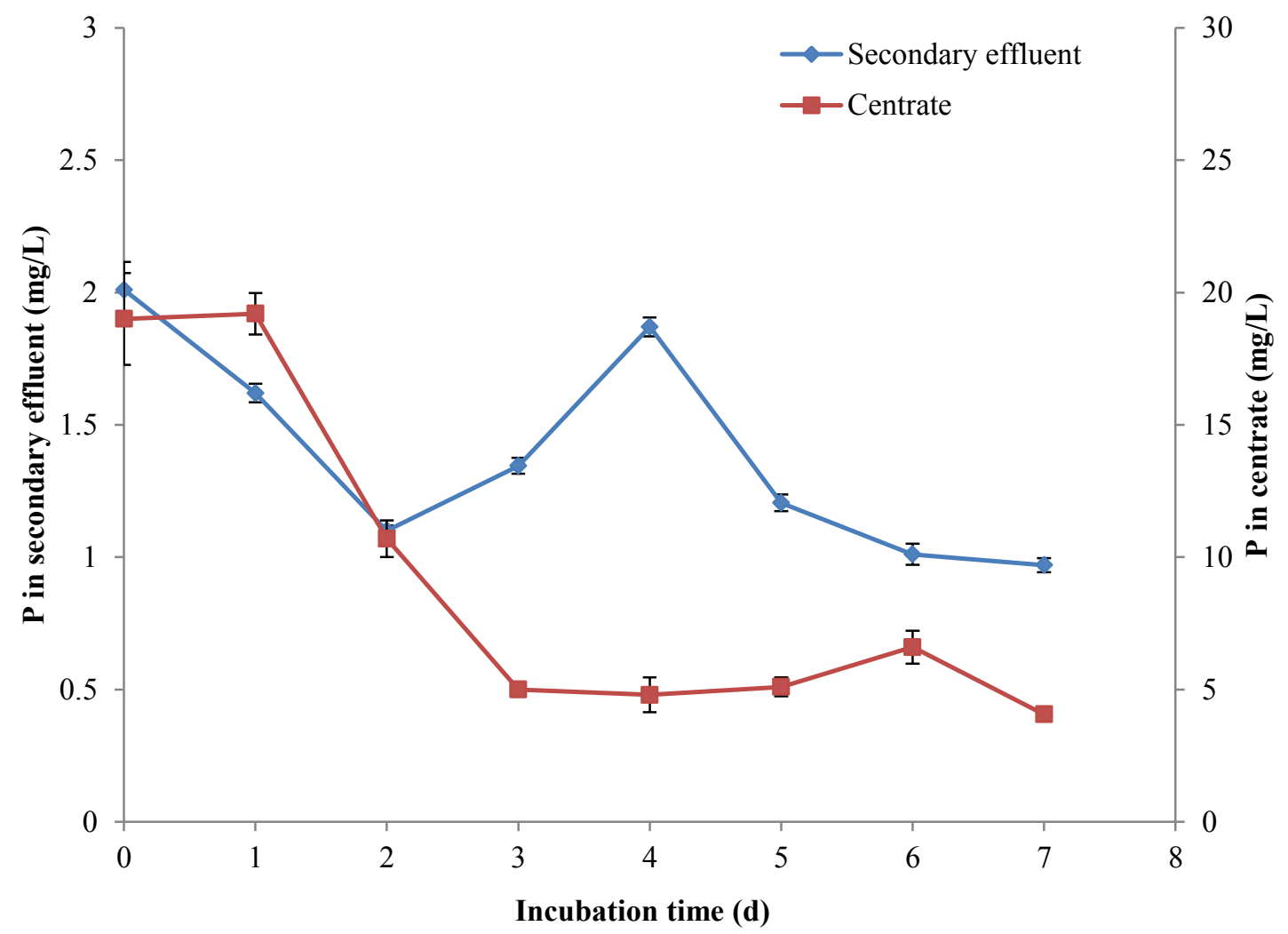

Figure 4.6 Dissolved phosphorus concentration in secondary effluent and centrate during the experiment

\subsubsection{Removal of sCOD}

Besides nutrients removal, reduction in sCOD concentration was also observed during microalgae treatment. The reduction in $\mathrm{SCOD}$, however, was not as high as the reduction in the nutrients particularly in the secondary effluent (Figure 4.7). The carbonaceous matter in the secondary effluent left after activated sludge treatment are mostly recalcitrant and thus may not be easily utilized by algae. The sCOD reduction for the secondary effluent and centrate during the 7 days experiment period was 29.5 and $32.8 \%$, respectively. Figure 4.7 illustrates the reduction in SCOD concentration in the secondary effluent and centrate samples. On day 2, an increase in SCOD was observed in the secondary effluent and centrate likely due to the die off of some bacteria and microalgae 
during their adaptation to the new conditions. As a result, microalgae have the potential to improve COD removal and hence can effectively contribute to wastewater treatment not only for the removal of nutrients but also for the removal of organic matter.

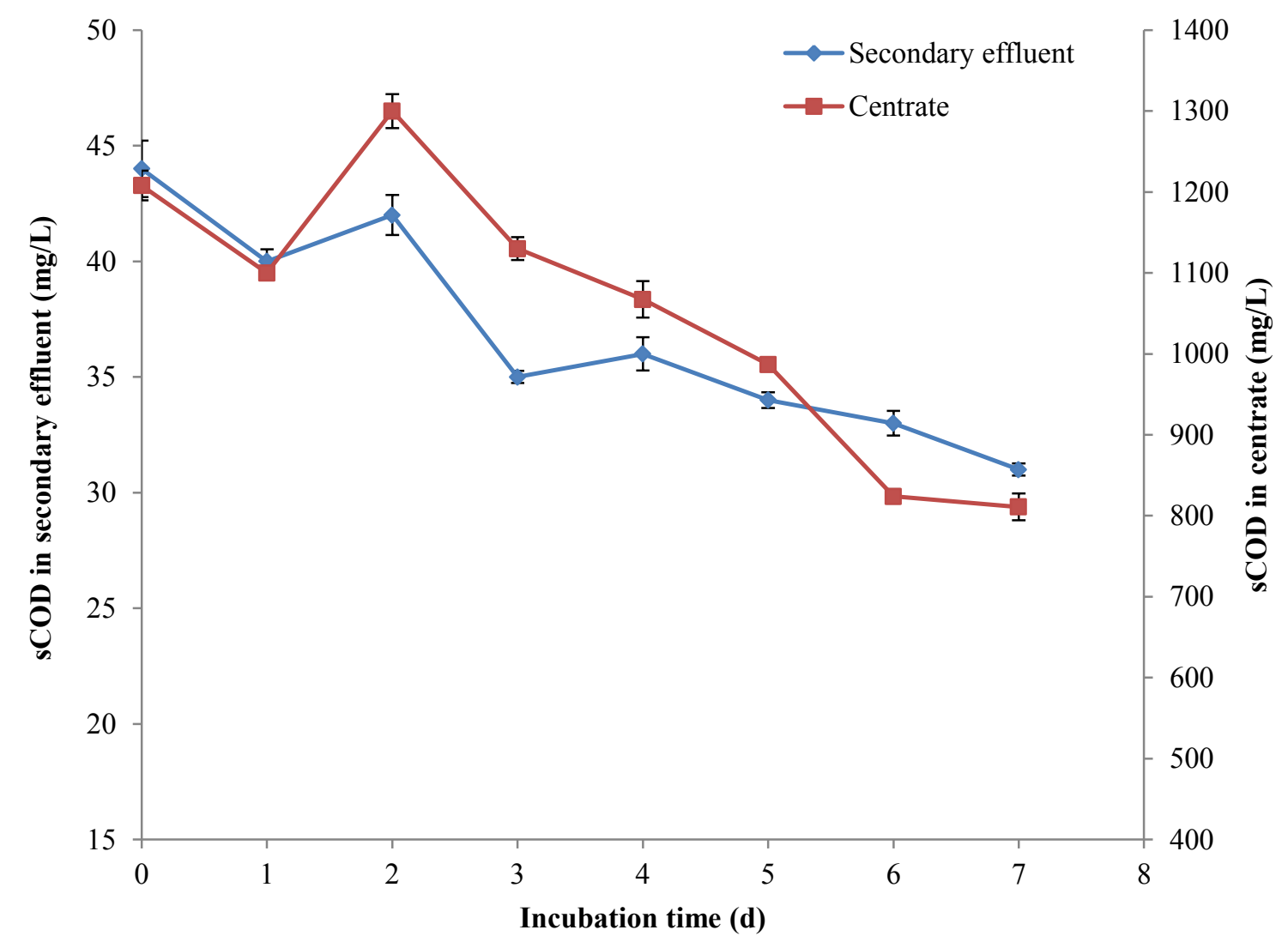

Figure 4.7 sCOD concentration in secondary effluent and centrate during the experiment

\subsubsection{Inactivation of total coliform}

The efficiency of microalgae treatment to remove pathogens was investigated by monitoring the decay of indicator bacteria. TC was chosen as an indicator organism for pathogens. Algae treatment in stabilization ponds and HRAPs has showed potential to assist in removing pathogens from wastewater. Previous research mentioned that TC dieoff may be caused by many factors. These factors include presence of light, elevated $\mathrm{pH}$, 
competition between species for nutrients, high oxidation reduction potential in algal system, and production of antibacterial substances by microalgae and sedimentation (Polprasert et al. 1983; Ansa et al., 2011). Figure 4.8 illustrates the decrease in TC colonies over time with microalgae treatment. There was a very rapid decrease in TC colony numbers during first day for both the secondary effluent and centrate. This may be attributed to competition with microalgae and presence of antibacterial substances excreted by microalgae. Elevated $\mathrm{pH}$ level would not be the reason for bacteria die-off during the first day. After two days, $\mathrm{pH}$ levels increased to 7.6 and 8.12 for secondary effluent and centrate, respectively (Figure 4.4) and that is one of the main reasons for the bacteria die-off (Figure 4.8). The reduction of TC colonies for both the secondary effluent and centrate during the 7 day experiment was 99.5 and $99.9 \%$, respectively. This experiment showed that microalgae treatment was very effective in inactivating TC indicating that microalgae have the potential to disinfect pathogenic organisms as well. 


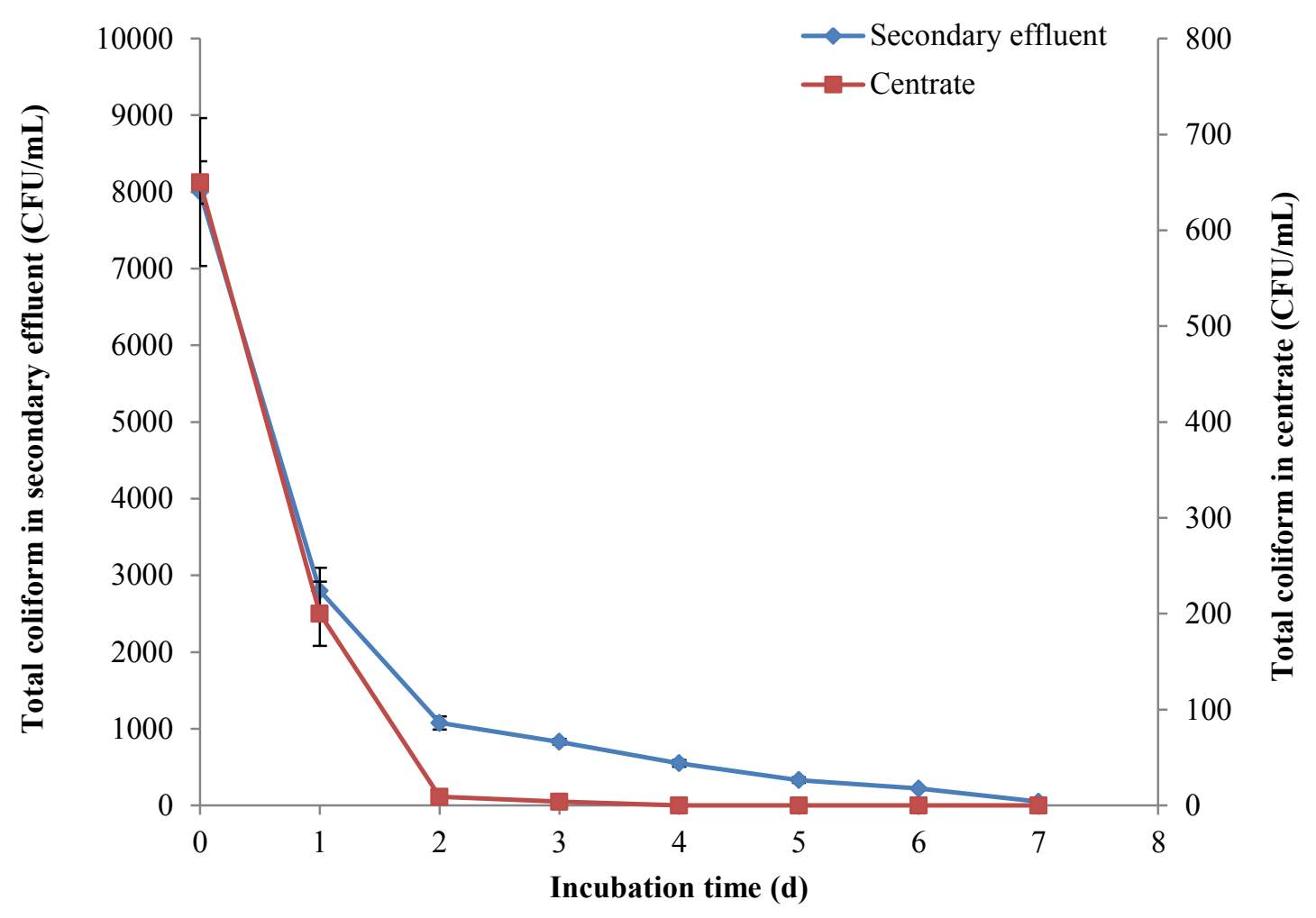

Figure 4.8 Total coliform removal in secondary effluent and centrate

\subsubsection{Separation of microalgae from wastewater}

Separation and harvesting of microalgae from wastewater was investigated in this experiment. At treatment plants, microalgae can be removed using gravity settling, filtration or centrifugation. Settling of microalgae was observed for $30 \mathrm{~min}$ in $100 \mathrm{~mL}$ graduated cylinders. In addition, the turbidity and absorbance of the supernatant on top was measured afterwards. Filtration characteristics were evaluated using the CST test. Microalgae have a negative surface charge that increases at high growth rates (Valigore et al., 2012). This charge helps to keep the cells in suspension and reduces gravity settling. However, the negative charge decreases at longer SRTs and lower growth rates (Henderson et al., 2008). Thus, particularly at low growth rates, extracellular polymers produced by microalgae and other organisms will likely facilitate self-flocculation (bio- 
flocculation) and increase the gravity settling performance. Table 4.2 illustrates the turbidity and ABS for the supernatant. As shown in this table, microalgae treatment can improve the settling performance for the centrate. The turbidity and ABS of the sludge supernatant decreased with the settling time in both samples. Table 4.3 illustrated the change in CST between days 6 and 7. As illustrated in this table, CST for the samples was decreasing with time indicating that a good filterability would be obtained with longer retention time.

Table 4.2 Sludge settling performance

\begin{tabular}{|c|c|c|c|c|c|c|}
\hline \multirow{2}{*}{} & \multicolumn{2}{|c|}{ After 30 min settling } & \multicolumn{2}{c|}{ After 60 min settling } & \multicolumn{2}{c|}{ After 1 day settling } \\
\cline { 2 - 7 } & $\begin{array}{c}\text { Secondary } \\
\text { effluent }\end{array}$ & Centrate & $\begin{array}{c}\text { Secondary } \\
\text { effluent }\end{array}$ & Centrate & $\begin{array}{c}\text { Secondary } \\
\text { effluent }\end{array}$ & Centrate \\
\hline $\begin{array}{c}\text { Turbidity } \\
\text { (NTU) }\end{array}$ & 46.5 & 629 & 40 & 611 & 22.4 & 512 \\
\hline $\mathrm{ABS}_{680}$ & 0.678 & 2.116 & 0.548 & 1.61 & 0.201 & 0.76 \\
\hline
\end{tabular}

Table 4.3 CST for secondary effluent and centrate

\begin{tabular}{|c|c|c|}
\hline & CST on day 6 & CST on day 7 \\
\hline Secondary effluent & 24.1 & 13.3 \\
\hline Centrate & 44.2 & 40 \\
\hline
\end{tabular}

\subsection{Conclusions}

In this study, the potential of microalgae to improve conventional wastewater treatment was investigated. Secondary effluent and centrate were treated with microalgae for 7 days and microalgae were successful in removing nutrients, sCOD and TC from wastewater. 
During this study, microalgae removed 29.5 and $32.8 \%$ of the sCOD from the secondary effluent and centrate, respectively. In addition, dissolved TN was reduced by 27 and $49.4 \%$ for both the secondary effluent and centrate, respectively. Dissolved phosphorus reduction for both the secondary effluent and centrate was 51.7 and $78.6 \%$, respectively. The high nutrient removal capacity of microalgae suggests that microalgae have the potential to be used for tertiary treatment and treatment of side streams at treatment plants under simple and inexpensive operational conditions. The results from this study also show the ability of microalgae to disinfect TC and potentially pathogenic bacteria. The reduction in TC colonies for both the secondary effluent and centrate during 7 days was 99.5 and $99.9 \%$, respectively. Therefore, a microalgae based treatment system can reduce or eliminate the need for chemical disinfection methods.

The results of this study indicate that microalgae based treatment systems can be incorporated in treatment plants in a very simple and inexpensive way without the need for providing $\mathrm{CO}_{2}$, nutrients, heating, $\mathrm{pH}$ adjustment, etc. Using microalgae would not only improve the overall wastewater treatment but would also generate biomass that has high energy value. The main drawback of treatment with microalgae is the high concentration of suspended solids (algae biomass) in wastewater that needs to be removed using a separation process such as settling, filtration, or centrifugation before discharging it into water bodies. 


\section{Chapter 5 Phase 2: Microalgae in combination with activated sludge \\ process}

\subsection{Introduction}

In Phase 2, the efficiency of microalgae treatment in combination with an activated sludge system was investigated for secondary treatment of wastewater. Primary effluent was treated with microalgae, activated sludge bacteria, and a mixture of microalgae and activated sludge bacteria in batch reactors for 5 days. The treatment performance was examined by daily measurement the concentrations of soluble $\mathrm{COD}, \mathrm{NH}_{3}-\mathrm{N}, \mathrm{NO}_{3}-\mathrm{N}$ and P. In addition, the ability of microalgae to reduce the aeration needs for biological treatment was evaluated.

\subsection{Materials and methods}

\subsubsection{Wastewater samples}

Primary effluent was obtained from the ROPEC wastewater treatment plant, Ottawa. The primary effluent was used directly in the experiments after collection without filtration or autoclaving. The primary effluent properties are shown in Table 5.1. Activated sludge was collected from the sludge line that follows from the secondary clarifier to the aeration tank.

Table 5.1 Primary effluent properties

\begin{tabular}{|c|c|c|c|c|c|c|c|}
\hline Properties & $\begin{array}{c}\mathrm{sCOD} \\
(\mathrm{mg} / \mathrm{L})\end{array}$ & $\begin{array}{c}\mathrm{NH}_{3}-\mathrm{N} \\
(\mathrm{mg} / \mathrm{L})\end{array}$ & $\begin{array}{c}\mathrm{NO}_{3} \mathrm{~N} \\
(\mathrm{mg} / \mathrm{L})\end{array}$ & $\begin{array}{c}\mathrm{P} \\
(\mathrm{mg} / \mathrm{L})\end{array}$ & $\mathrm{pH}$ & $\begin{array}{c}\mathrm{TS} \\
(\mathrm{mg} / \mathrm{L})\end{array}$ & $\begin{array}{c}\mathrm{TVS} \\
(\mathrm{mg} / \mathrm{L})\end{array}$ \\
\hline Primary effluent & 65 & 26 & 0.4 & 4 & 7.5 & 853.5 & 263.5 \\
\hline
\end{tabular}




\subsubsection{Microalgae}

Microalgae strain was Chlorella vulgaris as mentioned in Section 2.3.1. Chlorella vulgaris was cultivated and maintained separately in BBM medium. After cultivation, microalgae were removed from the medium by centrifugation at $3000 \mathrm{rpm}$ at $20^{\circ} \mathrm{C}$ for 15 min. Then, biomass was washed with distilled water to remove any residual media. Microalgae biomass was then used in the experiments by suspending it in wastewater samples at selected concentrations. Microalgae was quantified by measuring the sample absorbance at $680 \mathrm{~nm}$ and measuring sample TS and TVS.

\subsubsection{Experimental design}

Batch reactor experiments were conducted in three identical plastic tanks with dimensions of $13 \times 25 \times 20 \mathrm{~cm}$ as shown in Figure 5.1. Each tank had an active working volume of $2 \mathrm{~L}$. The tanks were incubated at room temperature $24 \pm 2{ }^{\circ} \mathrm{C}$ in the lab. Continuous florescent cool white light (two bulbs of 15 watt and 24 in.) was provided at $10 \mathrm{~cm}$ behind the tanks and with an intensity of $1.4-2 \mathrm{~mW} \mathrm{~cm}^{-2}$. Samples were daily taken from the reactors, filtered, and analyzed for soluble $\mathrm{COD}, \mathrm{P}, \mathrm{NH}_{3}-\mathrm{N}$ and $\mathrm{NO}_{3}-\mathrm{N}$. Also, TS, TVS, ABS, pH and DO were measured daily. The temperature was measured by a digital thermometer. The experimental period was 5 days and each test sample had three replicates. Microalgae, activated sludge and mixed microalgae and bacteria samples were maintained in suspension by using a magnetic stirrer at $100 \mathrm{rpm}$. In addition, an equal and constant aeration rate (measured through flow meter) was provided for the three samples by bubbling air through stone diffusers placed on the bottom of the tanks. The reactors were covered on top, and evaporation was taken into consideration by 
calculating the daily amount of volume that was lost. No $\mathrm{pH}$ or chemical adjustments were made throughout the experiments. The three tanks were seeded with different concentrations of microalgae and RAS as indicated in Table 5.2. Tank A served as the control for microalgae and had only RAS. Similarly, Tank C served as the control for RAS and had only microalgae. Tank B had equal amounts of microalgae and activated sludge (Table 5.2).

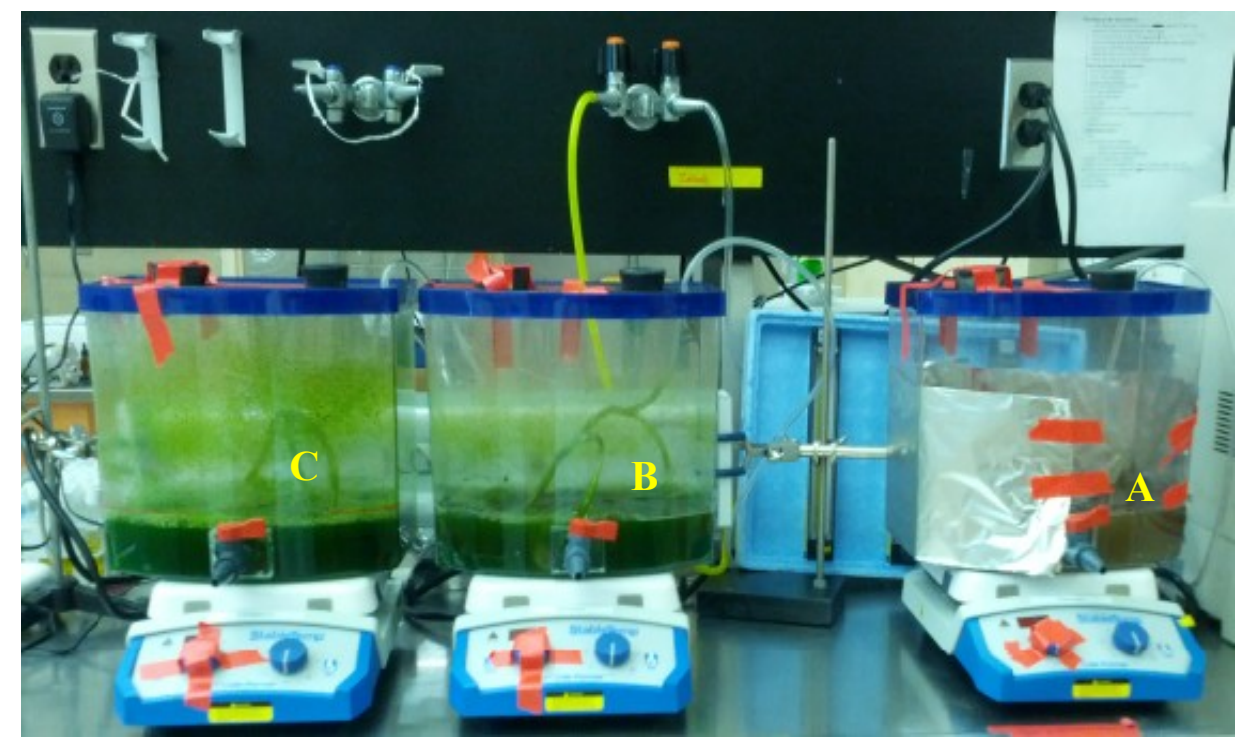

Figure 5.1 Batch reactors used in the experiments. Reactor A (1000 mg/L RAS), B (500 mg/L RAS+500 mg/L microalga), C (1000 mg/L microalga)

Table 5.2 Start-up concentrations of microalgae and activated sludge in the tanks

\begin{tabular}{|l|l|l|}
\hline Tanks & Microalgae & Activated sludge \\
\hline Tank A & none & $1000 \mathrm{mg} / \mathrm{LTVS}$ \\
\hline Tank B & $500 \mathrm{mg} / \mathrm{LTVS}$ & $500 \mathrm{mg} / \mathrm{L} \mathrm{TVS}$ \\
\hline Tank C & $1000 \mathrm{mg} / \mathrm{L} \mathrm{TVS}$ & none \\
\hline
\end{tabular}




\subsubsection{Chemical analysis}

Chemicals were analyzed daily by taking liquid samples from the reactor using a pipette during the experiment period. The samples were centrifuged for $15 \mathrm{~min}$ at $20^{\circ} \mathrm{C}$ and the supernatant was filtered through a $0.45 \mu \mathrm{m}$ syringe filter (mixed cellulose ester syringe filter, Glassco Laboratory Equipment). After filtration, supernatant samples were immediately analyzed for dissolved concentrations of $\mathrm{COD}, \mathrm{NH}_{3}-\mathrm{N}, \mathrm{NO}_{3}{ }^{-}-\mathrm{N}$ and $\mathrm{P}$.

\subsection{Results}

\subsubsection{Biomass growth and monitoring}

The growth of activated sludge bacteria, mixed bacteria-microalgae and microalgae cultures in primary effluent was determined by measuring the TS and TVS in reactors A (activated sludge and no algae), B (equal amounts of activated sludge and microalgae), and $\mathrm{C}$ (microalgae and no activated sludge) (Figures 5.2 and 5.3). The three samples showed relatively similar TS and TVS increases over the 5 days period. As shown in Figure 5.2, TS concentrations were increasing steadily with occasional fluctuations. Solids concentrations for samples $\mathrm{A}$ and $\mathrm{C}$ did not exhibit a decrease during the 5 days experiment period. In contrast, TS concentration slightly decreased for sample B on the second day but continued to increase afterwards. This was probably due to the complexity of the bacteria-microalgae culture and the challenges that both organisms were facing such as competition between species and the environmental conditions. 


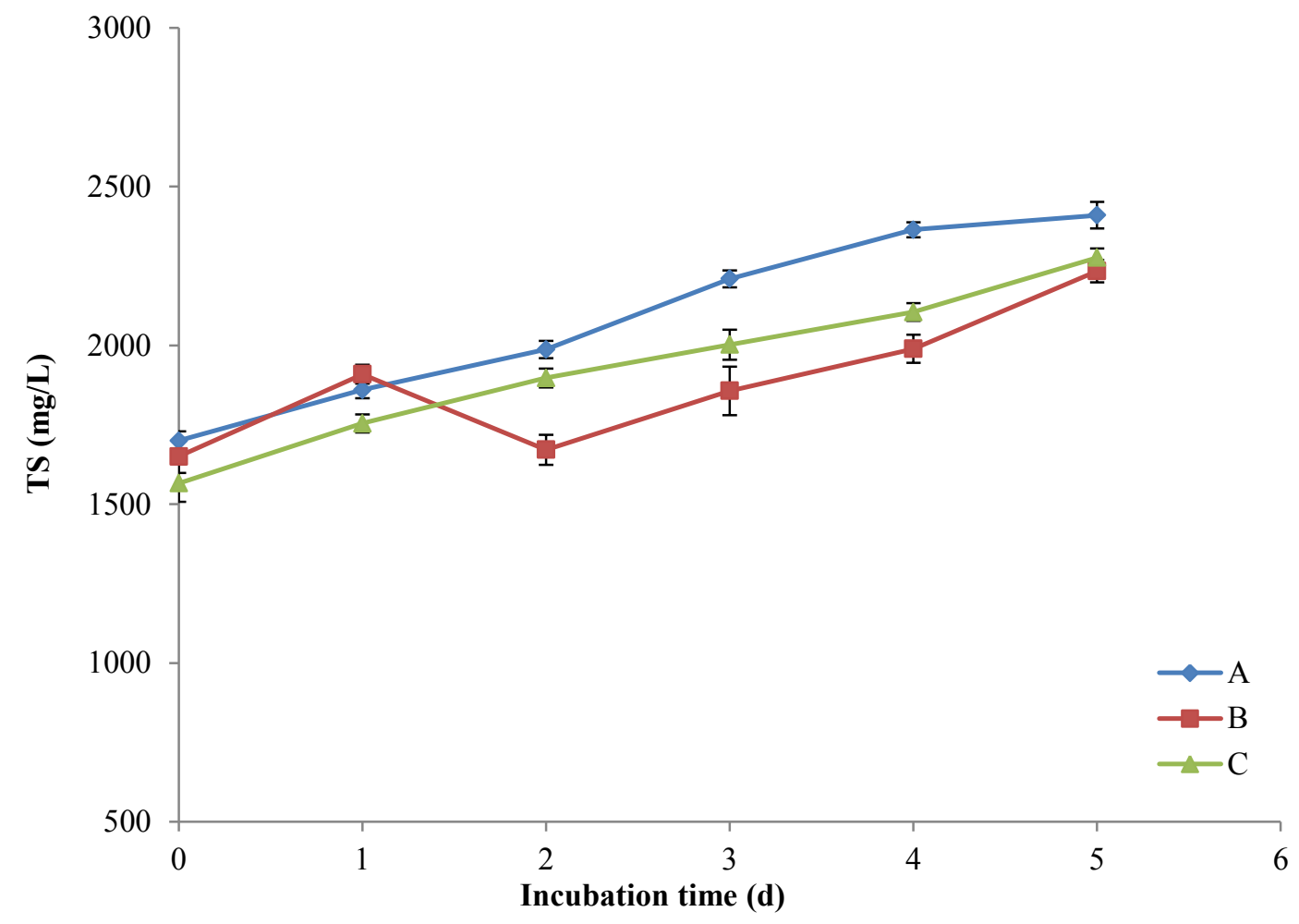

Figure 5.2 Total solids concentrations over the experimental period, A $(1000 \mathrm{mg} / \mathrm{L}$ RAS), B (500 mg/L RAS+500 mg/L microalga), C (1000 mg/L microalga)

Somewhat similar growth patterns were also observed when the TVS data were examined. As illustrated in Figure 5.3, volatile solids concentration was stable for sample A during the experimental period. For samples B and C the increases observed in volatile solids were similar to the increases observed in TS and indicated a steady growth of biomass in both samples. 


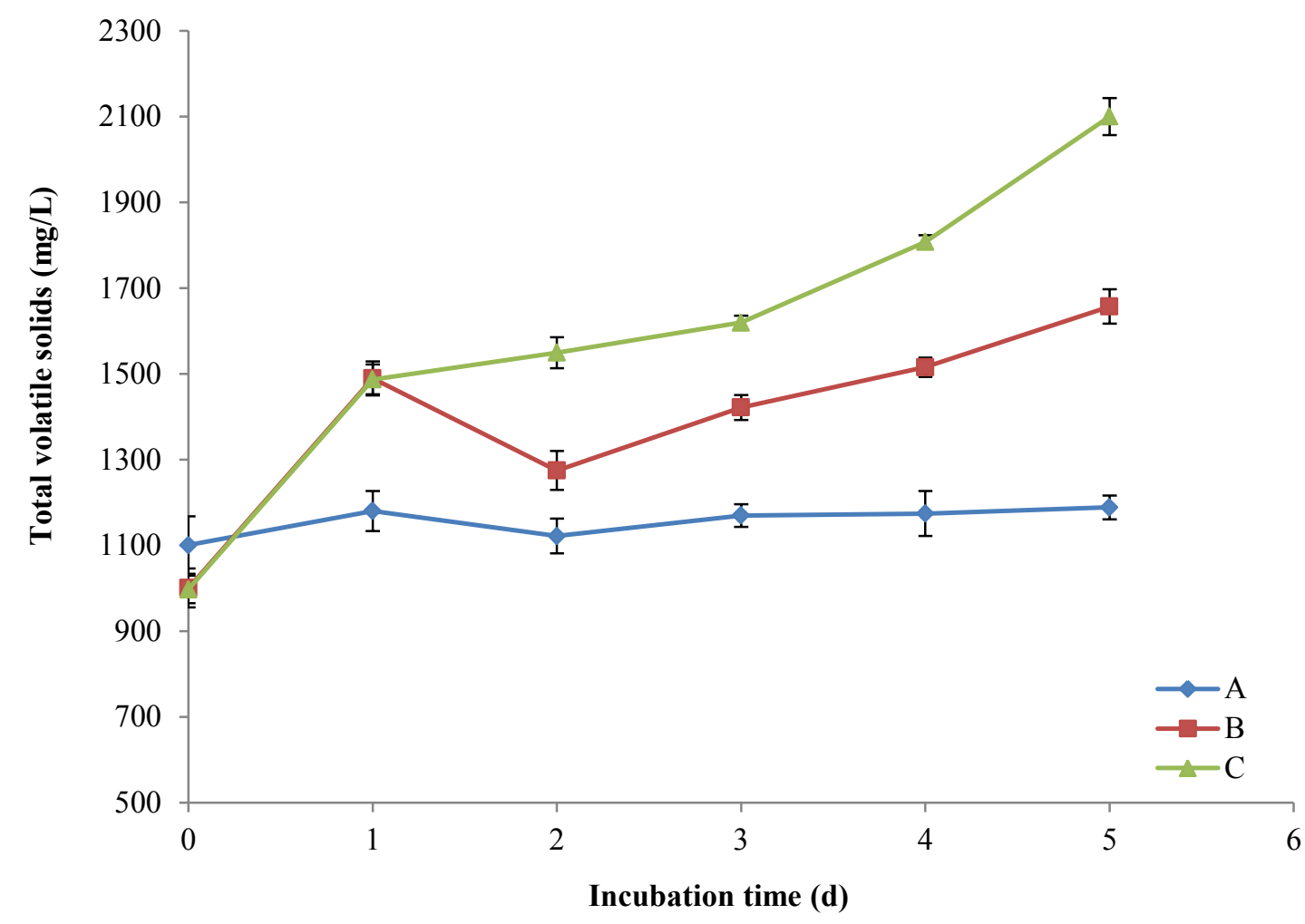

Figure 5.3 Total volatile solids concentrations over the experimental period, A (1000 mg/L RAS), B (500 mg/L RAS+500 mg/L microalga), C (1000 mg/L microalga)

\subsection{2 $\mathrm{pH}$ and $\mathrm{DO}$ concentrations}

Microalgae growth caused $\mathrm{pH}$ levels to increase significantly during the experimental period due to photoautotrophic growth of microalgae, where consumption of $\mathrm{CO}_{2}$ by microalgae causes $\mathrm{pH}$ to increase (Borowitzka, 1998). No $\mathrm{pH}$ adjustment was made during the experiment. Elevated $\mathrm{pH}$ levels may have different effects on wastewater treatment. High $\mathrm{pH}$ causes phosphorus precipitation through the formation of hydroxyapatite (Diamadopoulos and Benedek, 1984), helps to improve flocculation of sludge and the subsequent harvesting process (Borowitzka, 1998) and helps to reduce coliform bacteria (Polprasert et al., 1983). Figure 5.4 illustrates the change in $\mathrm{pH}$ level during the experimental period. $\mathrm{pH}$ decreased from 7.5 to 6.81 for sample A likely due to bacterial activity. For samples $\mathrm{B}$ and $\mathrm{C}, \mathrm{pH}$ level increased starting from day two of the 
experiment until day five when it was stabilized. $\mathrm{pH}$ level increased for samples B and C from 7.52 and 7.55 to 8.17 and 8.76 , respectively. As a result, the presence of microalgae increased the $\mathrm{pH}$ level which has many beneficial effects on wastewater treatment process as long as the increases are not extreme.

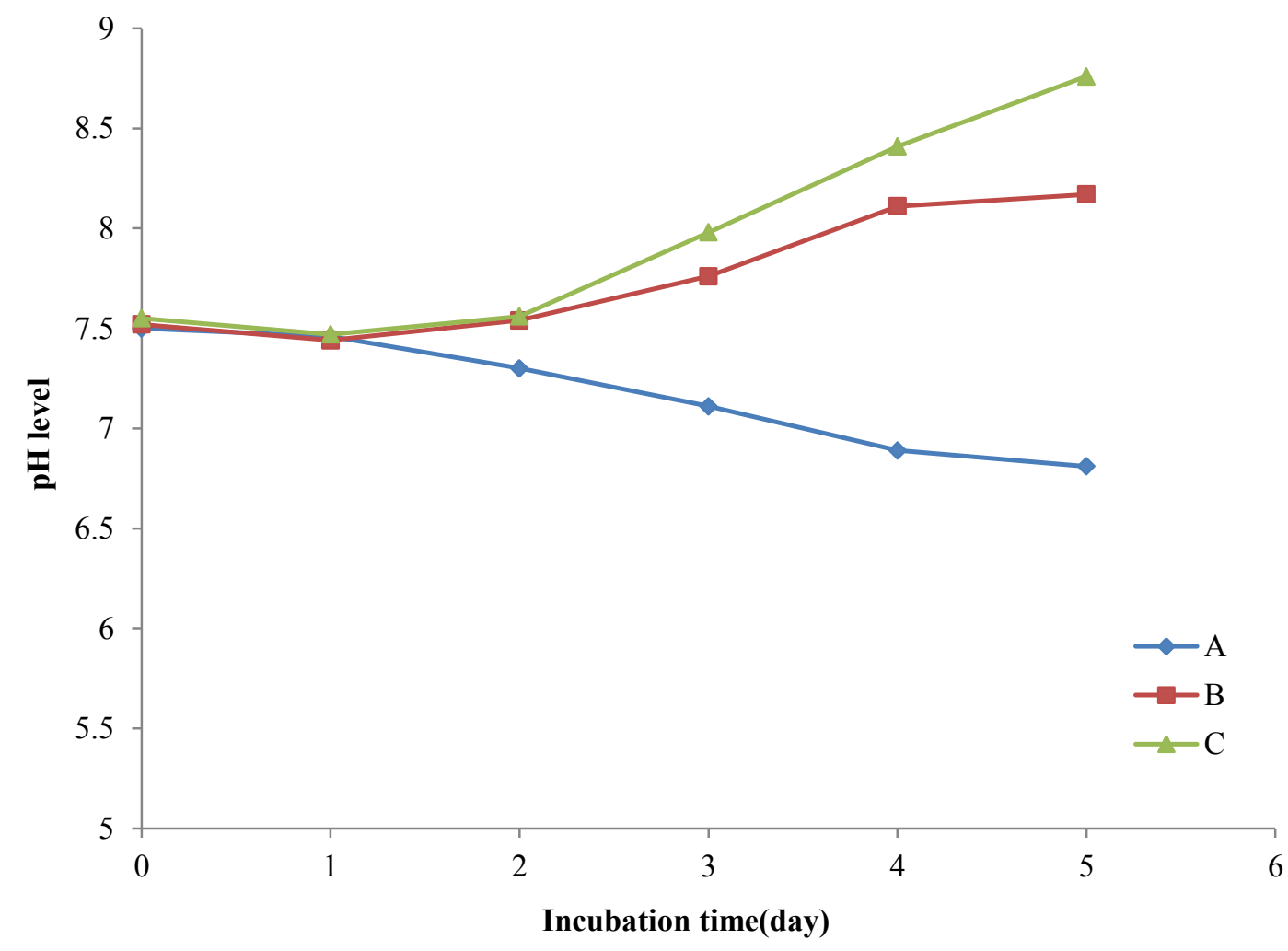

Figure 5.4 pH level developments along the experiment, A (1000 mg/L RAS), B (500 $\mathrm{mg} / \mathrm{L}$ RAS+500 mg/L microalga), C (1000 mg/L microalga)

Another benefit of microalgae is the oxygen release. Microalgae release oxygen through photosynthesis and uptake of carbon dioxide. Microalgae can potentially be used as an oxygen provider for aerobic organisms that decompose organic matter and reduce the aeration demand and cost at the treatment plants in an environmentally friendly way. In this experiment, an equal and constant aeration rate was provided to the three reactors by using flow meters. The change in DO concentration is illustrated in Figure 5.5. It was 
noticed that samples B and C maintained the same level of oxygen or even higher in some days, while DO concentration was steadily decreasing for sample A that had activated sludge bacteria only.

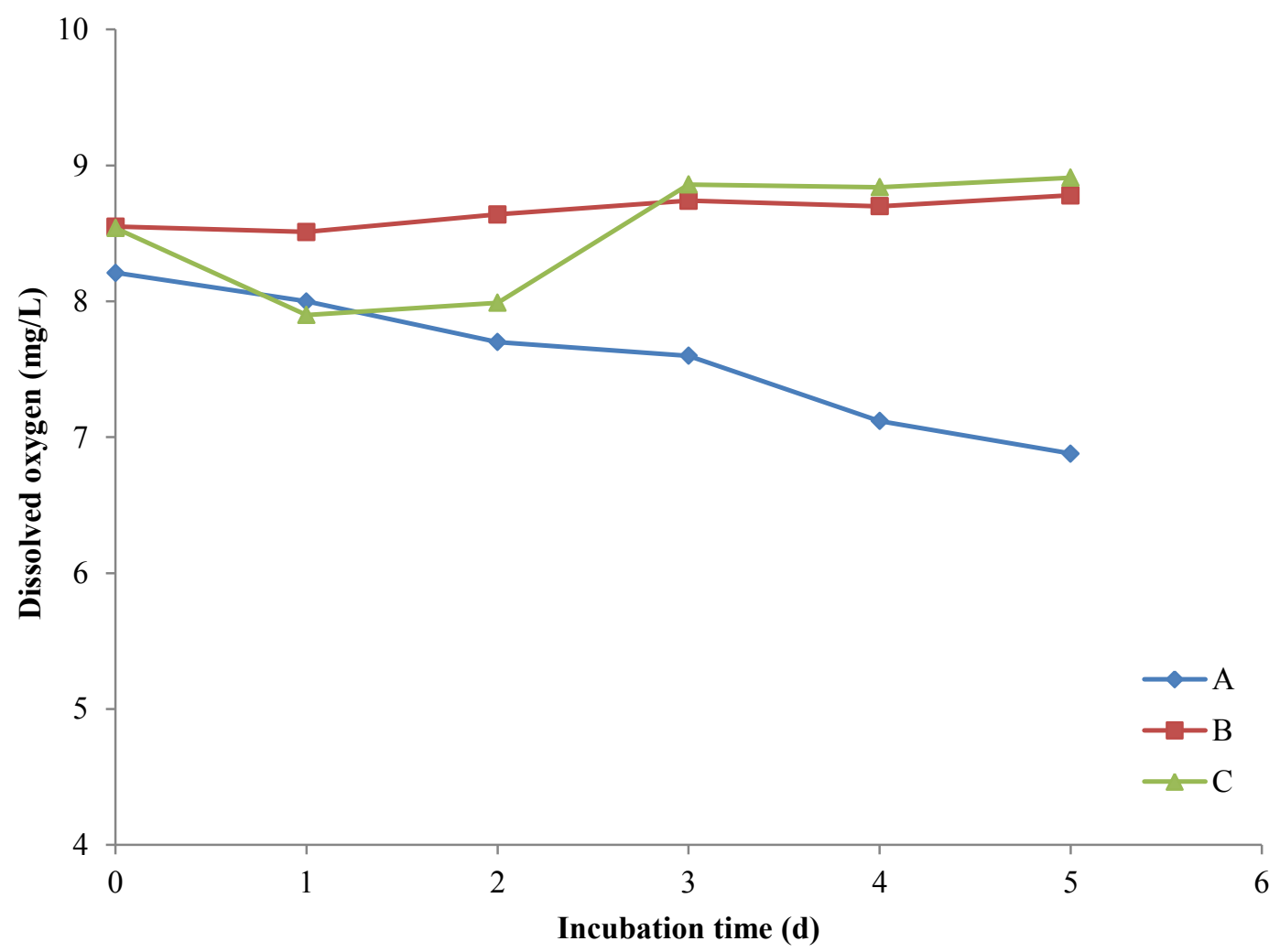

Figure 5.5 Dissolved oxygen concentration during the experimental period, A (1000 mg/L RAS), B (500 mg/L RAS+500 mg/L microalga), C (1000 mg/L microalga)

\subsubsection{COD uptake}

Microalgae are photoautotrophs that uptake $\mathrm{CO}_{2}$ as an inorganic carbon source for cell synthesis. However, some algae species such as Chlorella can grow under mixotrophic conditions in which they can alter between uptake of $\mathrm{CO}_{2}$ and assimilation of dissolved organic carbon depending on the availability. Figure 5.6 illustrates the change in sCOD concentration over the experimental period. sCOD concentration slightly decreased for sample A (activated sludge and no algae), while it decreased substantially for the samples 
$\mathrm{B}$ (equal amounts of activated sludge and microalgae) and $\mathrm{C}$ (microalgae and no activated sludge). The initial SCOD concentrations in reactors were adjusted to be the same for all samples by adding glucose when needed, which allowed to better observe the performance of the reactors in SCOD removal and comparison of results. SCOD reductions in reactors $\mathrm{A}, \mathrm{B}$ and $\mathrm{C}$ were $1.5,65.6$ and $77.8 \%$, respectively.

sCOD concentration showed an increase on the second day of experiments for all three samples. This increase was likely caused by the initial die-off of organisms due to the adjustment period and acclimation of bacteria and microalgae to the new conditions. After the second day, sCOD decreased consistently for all three samples until the end of the experiments. sCOD reduction in sample B (50\% microalgae) was similar to that of sample C (100\% microalgae) indicating that the difference in algae and bacteria concentrations did not result in a substantial difference in SCOD removal. However, compared to the activated sludge reactor (A), reactors that had microalgae (B and C) showed a much higher sCOD removal (1.5\% for sample A versus $65.6 \%$ and $77.8 \%$ for samples B and C, respectively). 


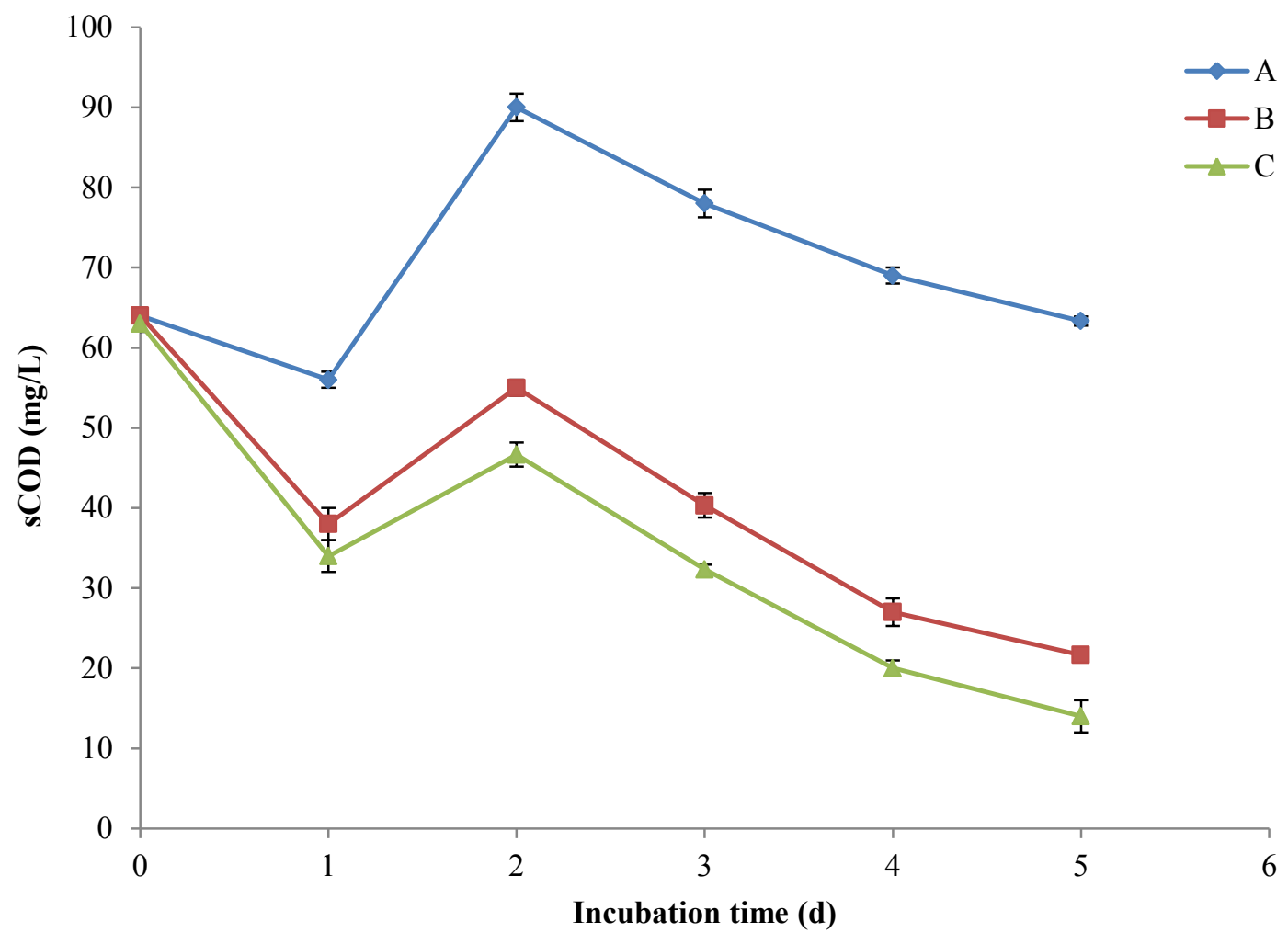

Figure 5.6 sCOD concentration with the time, A $(1000 \mathrm{mg} / \mathrm{L}$ RAS $)$, B $(500 \mathrm{mg} / \mathrm{L}$ RAS $+500 \mathrm{mg} / \mathrm{L}$ microalga $), C$ (1000 $\mathrm{mg} / \mathrm{L}$ microalga)

\subsubsection{Ammonia removal}

Ammonia-nitrogen $\left(\mathrm{NH}_{3}-\mathrm{N}\right)$ removal was also measured during the experiments. Microalgae mainly use inorganic nitrogen as a nutrient source for their cell synthesis and ammonia is the first preferable form of inorganic nitrogen for microalgae. Figure 5.7 illustrates the change in $\mathrm{NH}_{3}-\mathrm{N}$ concentration during the experimental period. During the first day, $\mathrm{NH}_{3}-\mathrm{N}$ concentration increased in all samples likely due to the acclimation of wastewater bacteria and algae to the new conditions. The increase in $\mathrm{NH}_{3}-\mathrm{N}$ concentration of sample A was higher than that of samples B and C indicating that presence of microalgae prevented some of the increase in ammonia by better removing ammonia compared to activated sludge sample. $\mathrm{NH}_{3}-\mathrm{N}$ concentration dropped rapidly on day two for all samples, particularly in the samples that contained microalgae. $\mathrm{NH}_{3}-\mathrm{N}$ 
reductions during the 5 days for samples A, B and C were 46.4, 99.9 and $99.9 \%$, respectively. Therefore, microalgae were able to remove the $\mathrm{NH}_{3}-\mathrm{N}$ completely both for samples $\mathrm{B}$ and $\mathrm{C}$. There are three possible mechanisms that contribute to $\mathrm{NH}_{3}-\mathrm{N}$ removal: microalgae uptake, conversion to nitrate and potential ammonia volatilization due to elevated $\mathrm{pH}$. Uptake by microalgae is by far the main removal mechanism for ammonia. For example, Grobbelaar (2004) showed that about $80 \%$ of TN removed was due to assimilation by microalgae for cell synthesis.

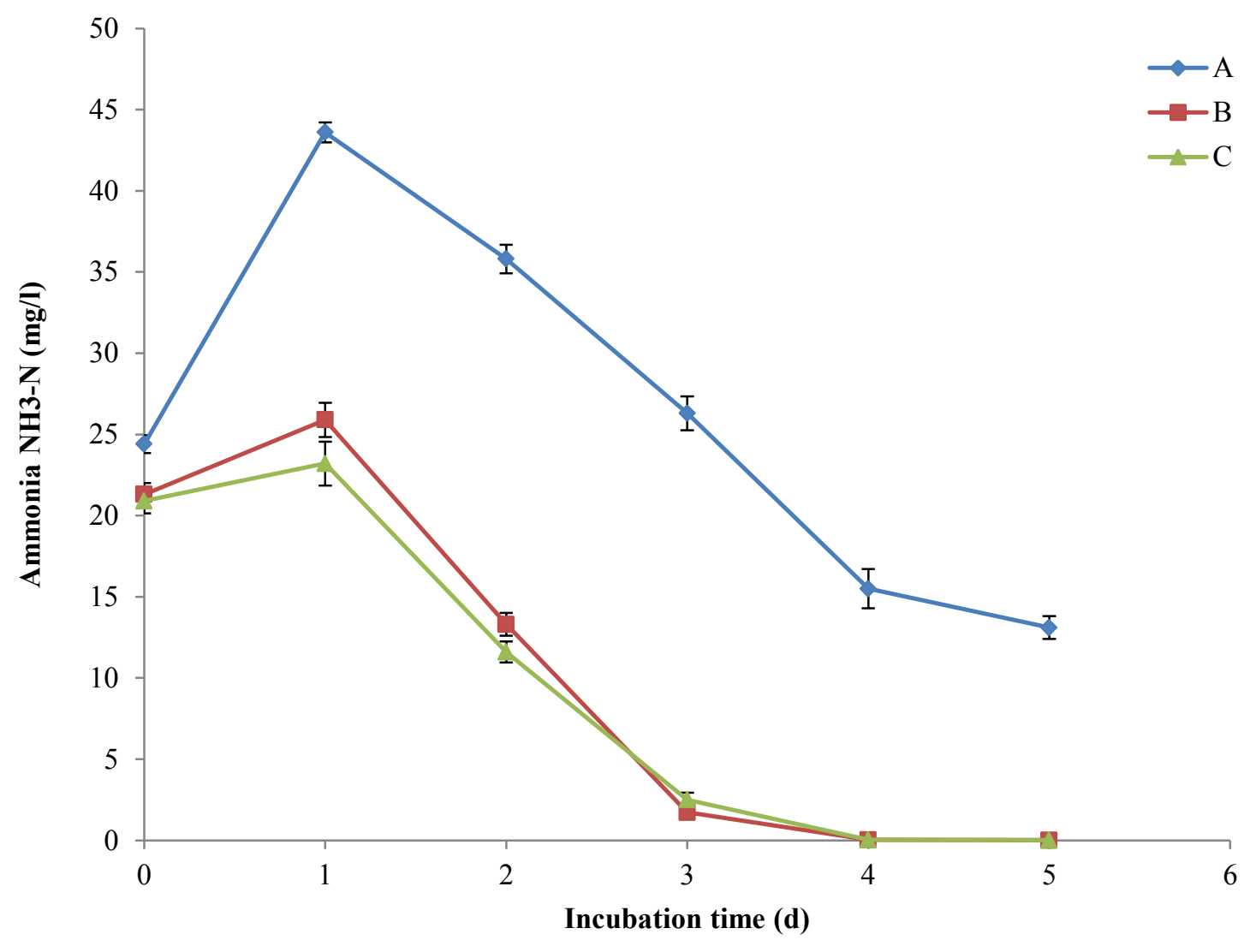

Figure 5.7 The change in ammonia-nitrogen concentration with time, $A(1000 \mathrm{mg} / \mathrm{L}$ RAS), B (500 mg/L RAS+500 mg/L microalga), C (1000 mg/L microalga)

An increase in the nitrate concentration was also observed during the experiments due to nitrification of some of the ammonia to nitrate in the presence of oxygen (Figure 5.8). 
However, the increase in nitrate was less than $4 \mathrm{mg} / \mathrm{L}$ whereas the decrease in $\mathrm{NH}_{3}-\mathrm{N}$ was approximately $25 \mathrm{mg} / \mathrm{L}$, which confirmed that the decrease in ammonia concentration was related to microalgae uptake rather than nitrification. Furthermore, after a consistent increase in nitrate, a decrease in nitrate was observed in all samples on day 5 when ammonia concentrations were very low. Microalgae assimilate ammonia as the first inorganic nitrogen choice but it can also assimilate nitrate when ammonia concentration is depleted.

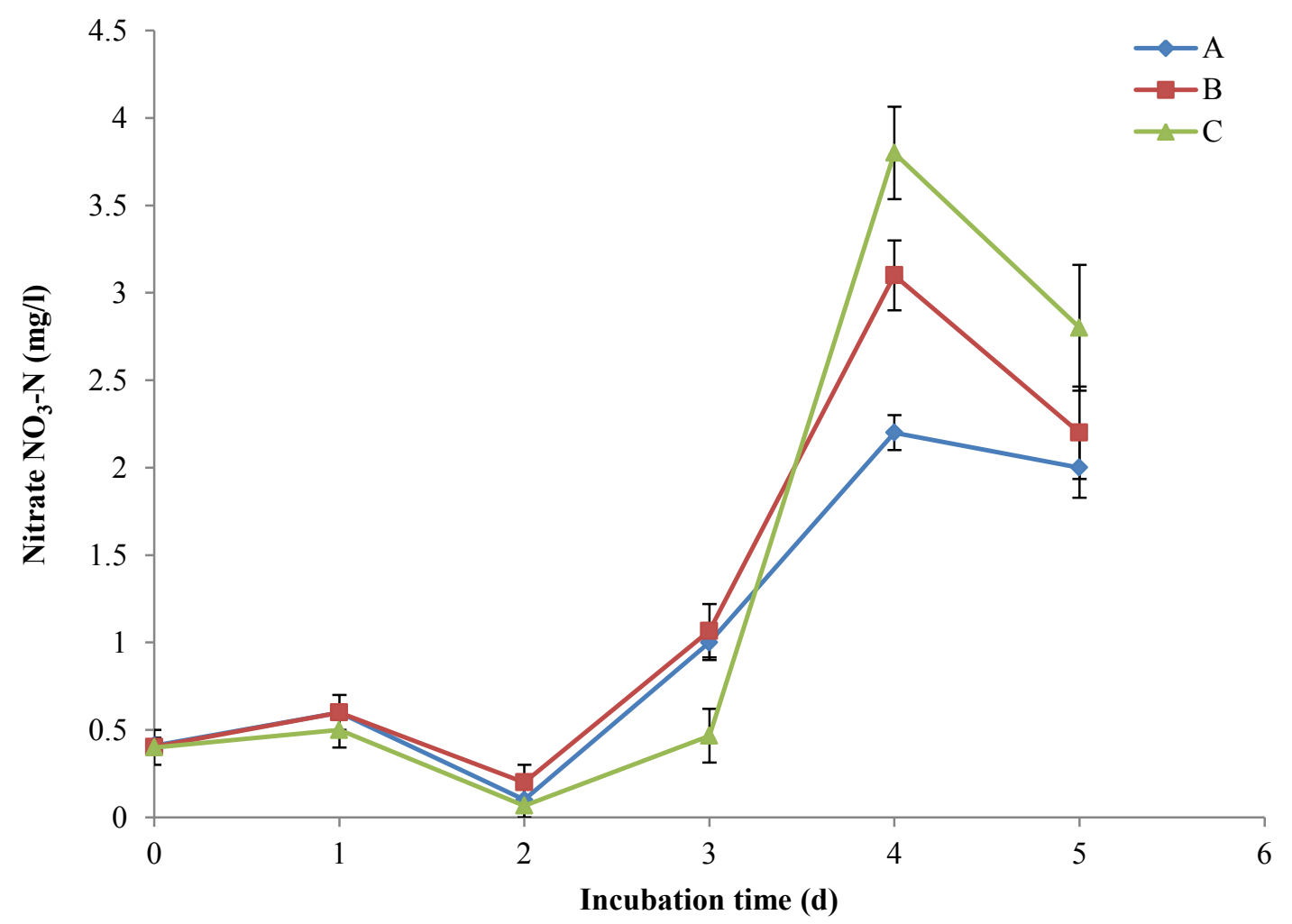

Figure 5.8 The change in nitrate concentration with time, A (1000 mg/L RAS), B (500 mg/L RAS+500 mg/L microalga), C (1000 mg/L microalga) 


\subsubsection{Phosphorus removal}

Dissolved total phosphorus removal was also monitored during the experiments. Figure 5.9 illustrates the concentration of dissolved total phosphorus. As shown, there was an increase in P concentration for sample A (RAS only) during the first two days followed by a decrease in the remaining days resulting in an overall increase in soluble phosphorus by the end of the experiment. The increase was likely due to bacteria die-off and solubilization of organic matter containing phosphorus, and activated sludge bacteria were not able to assimilate the released phosphorus. In contrast, the presence of microalgae in the other two samples helped in reducing the dissolved phosphorus concentration. The removal of dissolved phosphorus for samples B and C were $81.3 \%$ and $73.2 \%$, over the 5 days experimental period. There were two mechanisms that likely helped with the soluble phosphorus removal; assimilation of phosphorus by microalgae and precipitation of phosphorus as a result of high $\mathrm{pH}$ level (Munoz et al., 2004). However, assimilation by microalgae is more likely to be the main removing mechanism because soluble phosphorus concentration started to decrease from the first day when $\mathrm{pH}$ was still neutral. As a result, incorporation of microalgae to the activated sludge system in the aeration tank might strongly improve phosphorus removal. Phosphorus is an essential nutrient for microalgae that comprises $1 \%$ of the cell's dry weight (Brown and Shilton, 2014). Microalgae have the ability to uptake more than what they need through their ability to synthesize and accumulate polyphosphate in the cells (Larsdotter, 2006) and use it when there is a phosphorus deficiency. 


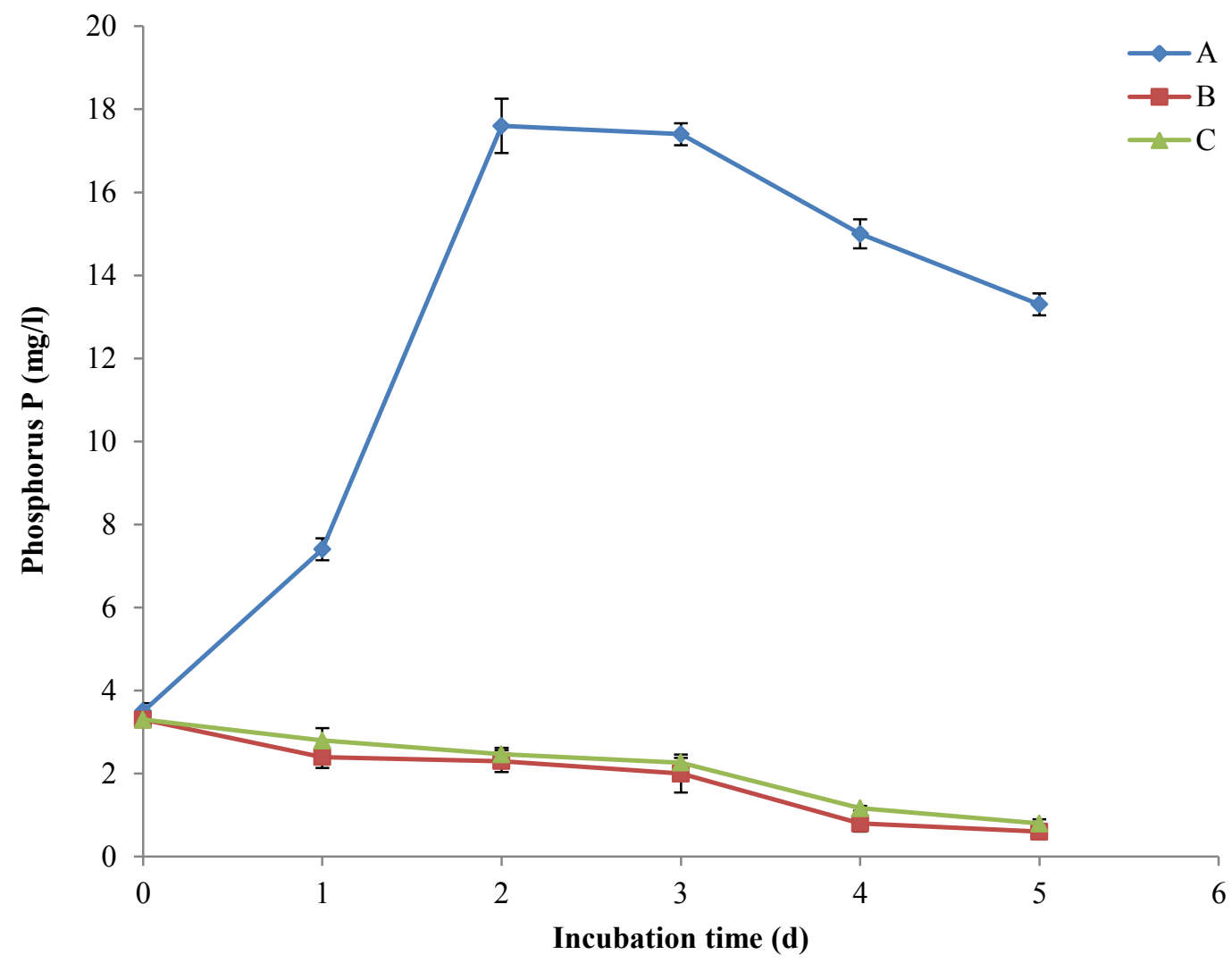

Figure 5.9 The change in phosphorus concentrations with time, A $(1000 \mathrm{mg} / \mathrm{L} \mathrm{RAS})$, B (500 mg/L RAS $+500 \mathrm{mg} / \mathrm{L}$ microalga), C (1000 mg/L microalga)

\subsubsection{Settling performance}

Separation of the bacteria and algae biomass is essential at the end of the wastewater treatment. Harvested microalgae can be converted to biogas in anaerobic digesters at the treatment plant or to biofuel in a processing facility. Therefore, it was important to evaluate the settling performance of the biomass generated from reactors $\mathrm{A}, \mathrm{B}$, and $\mathrm{C}$. Table 5.3 shows the ABS at $680 \mathrm{~nm}$ and the turbidity of the supernatant from reactors A, $\mathrm{B}$ and $\mathrm{C}$ after $30 \mathrm{~min}$ and $1 \mathrm{~d}$ settling time. In this experiment, the separation and harvesting performance of the three samples was compared by using simple gravity settling tests. No coagulants or flocculants were added and the samples bioflocculated and settled naturally. After 30 min. and 1 day of gravity settling, all samples showed 
substantial reductions in their absorbance and turbidity values. The reductions in sample absorbance and turbidity were correlated with microalgae content, and samples that had higher microalgae content settled better. When the improvements in absorbance and turbidity for sample A (RAS only) and sample C (microalgae only) were compared between 30 min. and 1 day settling time, sample A had $52 \%$ and $27.9 \%$ reductions in absorbance and turbidity, whereas sample $\mathrm{C}$ had $88.3 \%$ and $71.9 \%$ reductions in absorbance and turbidity, respectively. When the absorbance and turbidity of samples among $\mathrm{A}, \mathrm{B}$, and $\mathrm{C}$ were compared after $30 \mathrm{~min}$. and 1 day settling, an increasing order in absorbance at $680 \mathrm{~nm}$ but a decreasing order in turbidity was observed. $680 \mathrm{~nm}$ is a specific wavelength where microalgae strongly absorb light and therefore it is used as a measure for estimating microalgae biomass in samples in the literature. Therefore, samples with higher microalgae content had higher absorbance at $680 \mathrm{~nm}$. When the absorbance values of samples at $254 \mathrm{~nm}$ were checked, it was found that the absorbance values at $254 \mathrm{~nm}$ followed the same trend with turbidity (Table 5.3).

Table 5.3 Settling performance for samples A, B and C

\begin{tabular}{|c|c|c|c|c|c|c|}
\hline \multirow{2}{*}{ Sample } & \multicolumn{2}{|c|}{ After 30 min settling } & \multicolumn{3}{c|}{ After 1 d settling } \\
\cline { 2 - 7 } & $\boldsymbol{A B S _ { 6 8 0 }}$ & $\begin{array}{c}\text { Turb. } \\
(\text { NTU) }\end{array}$ & $\boldsymbol{A B S}_{254}$ & $\boldsymbol{A B S}_{680}$ & $\begin{array}{c}\text { Turb. } \\
(\boldsymbol{N T U})\end{array}$ & $\boldsymbol{A B S}_{254}$ \\
\hline $\begin{array}{c}\boldsymbol{A} \\
(\boldsymbol{R A S})\end{array}$ & 0.840 & 129 & 3.255 & 0.402 & 93 & 2.295 \\
\hline $\begin{array}{c}\boldsymbol{B} \\
\text { (microalgae }+\boldsymbol{R A S})\end{array}$ & 1.067 & 101 & 2.461 & 0.162 & 34.7 & 1.375 \\
\hline $\begin{array}{c}\boldsymbol{C} \\
\text { (microalgae) }\end{array}$ & 1.167 & 95 & 2.379 & 0.137 & 26.7 & 1.31 \\
\hline
\end{tabular}




\subsection{Conclusions}

In this study, the performance of microalgae treatment combined with activated sludge treatment was evaluated for wastewater. The treatment efficiency was assessed by comparing the treatment performance of three samples: sample A with $100 \%$ RAS and no microalgae, sample B with 50\% microalgae and RAS, and sample C with 100\% microalgae. The presence of microalgae substantially improved wastewater treatment by reducing the concentration of soluble $\mathrm{COD}$, dissolved $\mathrm{P}$, and $\mathrm{NH}_{3}-\mathrm{N}$. Microalgae also provided additional oxygen to wastewater and increased the $\mathrm{pH}$. Elevated $\mathrm{pH}$ has some benefits on wastewater treatment such as it can facilitate the flocculation and settling of biomass (Borowitzka, 1998) and can help with disinfection as well.

During this study, sCOD reductions for samples A, B and C were 1.5, 65.6 and $77.8 \%$, respectively. The highest removal was for the sample with the highest microalgae concentration, but the results also indicated that bacteria and microalgae could work together to remove sCOD as an integrated system. Bacteria use $\mathrm{sCOD}$ and oxygen during their respiration and produce $\mathrm{CO}_{2}$ as a byproduct. Conversely, microalgae assimilate $\mathrm{CO}_{2}$ through photosynthesis and produce oxygen. Their combined use can provide a sustainable treatment system that has lower aeration needs and thus lower carbon print.

$\mathrm{NH}_{3}-\mathrm{N}$ was removed to a large extent during this study. Ammonia reduction for samples A, B and C were 46.4, 99.9 and $99.9 \%$, respectively. Microalgae had the ability to assimilate ammonia as it is the most important inorganic form of nitrogen for the synthesis of new microalgae cells. Stripping of ammonia due to high $\mathrm{pH}$ was not the main removal mechanism because ammonia started to decrease at neutral $\mathrm{pH}$. Also, there was 
an increase in nitrate concentration associated with the decrease in ammonia. It was observed that the nitrate uptake started when ammonia was depleted in the wastewater.

Dissolved phosphorus was efficiently removed from the samples containing microalgae. Soluble phosphorus reductions for samples B and C after 5 days were 81.3 and $73.2 \%$, respectively. No reduction was observed in soluble phosphorus concentration for sample A. Assimilation by microalgae was more likely the main removal mechanism because phosphorus concentration started to decrease from the first day when $\mathrm{pH}$ was neutral. The highest ammonia and phosphorus reduction was observed for sample B (50\% algae + $50 \%$ bacteria) that contained algae and bacteria indicating that bacteria and algae worked well together and their combined use improved the ammonia and phosphorus removal.

The results from this study indicate that microalgae can potentially be incorporated in an activated sludge system and improve the overall treatment performance by improving the removal of organic matter and nutrients while providing oxygen naturally. The final sludge generated from this system would produce higher biogas in anaerobic digesters due to its microalgae content in addition to the activated sludge bacteria. 


\section{Chapter 6 Conclusions, contributions and future work}

\subsection{Conclusions}

In this thesis, it was demonstrated that incorporating microalgae to wastewater treatment as a secondary or tertiary treatment system can successfully improve the treatment performance. In phase 1 , microalgae were introduced as a tertiary treatment to remove nutrients, residual COD and pathogens from secondary effluent and centrate. Microalgae were able to reduce $27,51.7$ and $29.5 \%$ of the dissolved N, P and COD, respectively from secondary effluent. Also, microalgae were able to reduce $49.4,78.6$ and $32.8 \%$ of the dissolved N, P and COD from centrate. In addition, microalgae reduced the coliform bacteria in secondary effluent and centrate by 99.5 and $99.9 \%$. Besides these advantages, microalgae treatment can result in high suspended solids concentration in the treated effluent and may need to be removed using an additional separation process such as sedimentation and filtration.

In phase 2 , the efficiency of microalgae treatment in combination with activated sludge process was investigated for secondary wastewater treatment. Three reactors were used: reactor A had primary effluent with RAS only, reactor B had primary effluent with 50\% RAS and 50\% microalgae, and reactor $\mathrm{C}$ had primary effluent with microalgae only. The results showed that combining microalgae with bacteria (sample B) in the aeration tank improved the removal of soluble COD, ammonia and phosphorus. Sample A was able to reduce 1.5 and $46.4 \%$ of the soluble COD and ammonia but it was not successful in removing dissolved phosphorus. Sample B was able to remove soluble COD, ammonia 
and phosphorus by 65.6, 99.9 and $81.3 \%$, respectively. Sample C was able to reduce soluble COD, ammonia and phosphorus by 77.8, 99.9 and 73.2\%, respectively.

In this study, an equal and constant aeration rate was provided to all reactors using flowmeters. Dissolved oxygen concentrations were almost same for samples B and C during the experiment (from start-up concentration of $8.54 \mathrm{mg} / \mathrm{L}$ to 8.78 and $8.91 \mathrm{mg} / \mathrm{L}$ for sample B and C at the end of the experiment). For sample A, however, the dissolved oxygen concentration was decreasing steadily (from start-up concentration of $8.21 \mathrm{mg} / \mathrm{L}$ to $6.88 \mathrm{mg} / \mathrm{L}$ at the end of the experiment). These results showed that the presence of microalgae increased the dissolved oxygen concentration in samples and can potentially decrease the aeration need during biological treatment. This is an important advantage in activated sludge process and can significantly reduce the energy needed for aeration.

\subsection{Contributions}

The results showed that incorporating microalgae to conventional wastewater treatment can improve the treatment performance. At treatment plants, microalgae can be grown in basins and used for the treatment of primary effluent, secondary effluent and side streams. Microalgae treatment can provide dual benefits of removing nutrients and residual COD as well as producing microalgae biomass. Microalgae biomass has high energy value and can be used to boost biogas generation in anaerobic digesters at treatment plants. In addition, microalgae can generate oxygen and reduce the energy required for aeration and hence the overall treatment cost. In this study, microalgae were cultivated under continuous light exposure. Under this condition, microalgae were growing as photoautotrophic organisms that use light as an energy source and $\mathrm{CO}_{2}$ as a 
carbon source. However, microalgae have the ability to grow under mixotrophic conditions (grow as photoautotrophic and heterotrophic organisms) when a light:dark cycle and carbon source are provided. In the presence of light, microalgae are capable of using $\mathrm{CO}_{2}$ as carbon source while using dissolved organic carbon as carbon source in dark.

Previous research on microalgae and wastewater treatment largely focused on pond and lagoon based systems. Other studies focused on using wastewater as a media for microalgae cultivation in photobioreactors with the goal of using microalgae for making biofuel. This study investigated the use of microalgae for wastewater treatment in a simple setting that can be incorporated in treatment plants without major changes to existing treatment trains. Therefore, no $\mathrm{CO}_{2}$ or heat supply was used and even under these rather simple and inexpensive conditions, the study successfully showed that microalgae can achieve important reductions in nutrients, COD, and indicator bacteria.

\subsection{Future work}

Some of the future research suggestions that may contribute to the development of microalgae based wastewater treatment systems are listed below:

- Microalgae are photosynthetic microorganisms that can be used as oxygen providers for aerobic bacteria during the decomposition of organic matter. Thus, further research is suggested to better utilize this advantage and reduce the overall aeration requirements for biological treatment. 
- Research should be focused on optimization of microalgae-bacteria populations to improve the gravity settling performance and dewaterability of the final biomass. For example, developing microalgae-bacteria cultures that have good self-aggregation properties would improve the settling performance. 


\section{References}

Al-Qasmi, M., Talebi, S., Al-Rajhi, S., \& Al-Barwani, T. (2012). A Review of Effect of Light on Microalgae Growth. World Congress on Engineering (pp. 608-610). London: WCE.

Ansa, E. D., Lubberding, H. J., \& Gijzen, H. J. (2008). Fecal Coliform Removal In AlgalBased Domestic Wastewater Treatment Systems.

Ansa, E., Lubberding, H., Ampofo, J., \& Gijzen, H. (2011). The role of algae in the removal of Escherichia coli in a tropical eutrophic lake. Ecological Engineering $37,317-324$.

Badger, M. R., Palmqvist, K., \& Yu, J. W. (1994). Measurement of CO2 and HCO3fluxes in cyanobacteria and microalgae during steady-state photosynthesis. Physiologia Plantarum, 90(3), 529-536.

Barbara, J. S. (2007). The fales promise of biofuels. The International Forum on Globalization and the Institute for Policy Studies.

Barbosa, M. J., \& Wijffels, R. H. (2004). Overcoming shear stress of microalgae cultures in sparged photobioreactors. Biotechnology and bioengineering, 85(1), 78-85.

Bare, W. F., Jones, N. B., \& Middlebrooks, E. J. (1975). Algae Removal Using Dissolved Air Flotation. Water Pollution Control Federation. 47, 153-169.

Becker, E. (1994). Microalgae, Biotechnology and Microbiology. Cambridge: Cambridge University Press. 
Benemann, J. R. (1979). Production of nitrogen fertilizer with nitrogen-fixing blue green algae . Enzyme and Microbial Technology, 83-90.

Benemann, J. R., \& Weissman, J. C. (1976). Biophotolysis: problems and prospects. Microbal Energy Conversion Erich Goltz, K. G., Gottingen, W. Germany, 413426.

Bhaya, D., Schwarz, R., \& Grossman, A. R. (2002). Molecular responses to environmental stress. In D. Bhaya, R. Schwarz, \& A. R. Grossman, The ecology of cyanobacteria (pp. 397-442). Netherlands: Springer Netherlands.

Bich, N. N., Yaziz, M. I., \& Bakti, N. A. (1999). Combination of Chlorella vulgaris and Eichhornia crassipes for Wastewater Nutrient Removal. Water Research 33.10, 2357-2362.

Borowitzka, M. (1998). Limits to growth . In M. Borowitzka, Wastewater treatment with algae (pp. 203-226). Berlin: Springer Berlin Heidelberg.

Brennan, L., \& Owende, P. (2009). Biofuels from microalgae-a review of technologies for production, processing, and extractions of biofuels and co-products. Renewable and sustainable energy reviews, 14(2), 557-577.

Brown, N., \& Shilton, A. (2014). Luxury uptake of phosphorus by microalgae in waste stabilisation ponds: current understanding and future direction. Reviews in Environmental Science and Bio/Technology , 1-8. 
Carvalho, A. P., Silva, S. O., Baptista, J. M., \& Malcata, F. X. (2011). Light requirements in microalgal photobioreactors: an overview of biophotonic aspects. Applied Microbiology \& Biotechnology, 1275-1288.

Cheirsilp, B., \& Torpee, S. (2012). Enhanced growth and lipid production of microalgae under mixotrophic culture condition: Effect of light intensity, glucose concentration and fed-batch cultivation. Bioresource Technology, 510-516.

Chorus, I., \& Bartram, J. (1999). Toxic cyanobacteria in water: A guide to their public health consequences, monitoring and management. Spon Press.

Correll, D. L. (1998). The role of phosphorus in the eutrophication of receiving waters: A review. Journal of Environmental Quality, 27(2), 261-266.

Craggs, R. J., McAuley, P. J., \& Smith, V. J. (1997). Wastewater Nutrient Removal by Marine Microalgae Grown on a Corrugated Raceway. Water research, 31(7), $1701-1707$.

Darley, W. M. (1982). Algal biology: A physiological approach. Oxford and Boston and St. Louis, Mo.: Blackwell Scientific Publications .

Day, J. G., Benson, E. E., \& Fleck, R. A. (1999). In vitro culture and conservation of microalgae: applications for aquaculture, biotechnology and environmental research. In Vitro Cellular \& Developmental Biology-Plant, 35(2), 127-136. 
Diamadopoulos, E., \& Benedek, A. (1984). The precipitation of phosphorus from wastewater through $\mathrm{pH}$ variation in the presence and absence of coagulants. Wat. Res., 18, 1175-1179.

Eaton, A. D., Clesceri, L. S., Rice, E. W., \& Greenberg, A. E. (2005). Standard Methods for The Examination of Water and Wastewater. Washington: American Public Health Association.

Fallowfield, H. J., Cromar, N. J., \& Evison, L. M. (1996). Coliform die-off rate constants in a high rate algal pond and the effect of operational and environmental variables. Water Science and Technology, 34(11), 141-147.

Fogg, G. E. (1975). Algal cultures and phytoplankton ecology. Wisconsin: The university of Wisconsin press.

Fontes, A., Vargas, M., Moreno, J., Guerrero, M., \& Losada, M. (1987). Factors affecting the production of biomass by a nitrogen-fixing blue-green alga in outdoor culture . Biomass, 33-43.

Fukami, K., Nishijima, T., \& Ishida, Y. (1997). Stimulative and inhibitory effects of bacteria on the growth of microalgae. In Live Food in Aquaculture (pp. 185-191). Springer Netherlands.

Garcia, J., Mujeriego, R., \& Hernandez-Marine, M. (2000). High rate algal pond operating strategies for urban wastewater nitrogen removal. Journal of Applied Phycology, 12(3-5), 331-339. 
Garcia, M., \& Becares, E. (1997). bacterial removal in three pilot-scale wastewater treatment systems for rural. Wat. Sci. Tech., 35(11), 197-200.

Garcia, M., Soto, F., Gonzalez, J. M., \& Becares, E. (2008). A comparison of bacterial removal efficiencies in constructed wetlands and algae-based systems. Ecological Engineering 32, 238-243.

Goldman, J. C., \& Carpenter, E. J. (1974). A kinetic approach to the effect of temperature on algal growth. Limnology and Oceanography, 19(5), 756-766.

Grima, M. E., Belarbi, E. H., Fernández, A. F., Medina, R. A., \& Chisti, Y. (2003). Recovery of microalgal biomass and metabolites: process options and economics. Biotechnology advances, 20(7), 491-515.

Grobbelaar, J. U. (1982). Potential of algal production. Water SA, 79-85.

Grobbelaar, J. U. (2000). Physiological and technological considerations for optimising mass algal cultures. Journal of Applied Phycology, 12(3-5) , 201-206.

Gutzeit, G., Lorch, D., Weber, A., Engels, M., \& Neis, U. (2005). Bioflocculent algalbacterial biomass improves low-cost wastewater treatment. Water Science \& Technology, 9-18.

HACH, C. (2007). DR 2800 Spectrophotometer Manual., (pp. 1-814). USA.

Hagen, K. N. (2009). Algae: Nutrition, Pollution Control and Energy Sources. New York: Nova Science Publishers, Inc. 
Hende, V. D., Sofie, Vervaeren, H., Desmet, S., \& Boon, N. (2011). Bioflocculation of microalgae and bacteria combined with flue gas to improve sewage treatment. New Biotechnology. 29, 23-31.

Henderson, R., Parsons, S., \& Jefferson, B. (2008). The impact of algal properties and pre-oxidation on solid-liquid separation of algae. Water Research 42 (8-9), 18271845.

Hoffmann, J. P. (1998). Wastewater treatment with suspended and nonsuspended algae. Journal of Phycology, 34(5), 757-763.

Hongyang, S., Yalei, Z., Chunmin, Z., Xuefei, Z., \& Jinpeng, L. (2011). Cultivation of chlorella pyrenoidosa in soybean processing wastewater. Bioresource Technology, 102(21), 9884-9890.

Hu, Q., Sommerfeld, M., Jarvis, E., Ghirardi, M., Posewitz, M., Seibert, M., et al. (2008). Microalgal triacylglycerols as feedstocks for biofuel production: perspectives and advances . The Plant Journal, 54(4), 621-639.

Ji, M. K., Abou-Shanab, R. A., Hwang, J. H., Timmes, T. C., Kim, H. C., Oh, Y. K., et al. (2013). Removal of Nitrogen and Phosphorus from Piggery Wastewater Effluent Using the Green Microalga Scenedesmus obliquus. Journal of Environmental Engineering, 139(9), 1198-1205.

Justice, C. M. (2012). Wastewater Systems Effluent Regulation. Canada: Canadain Minister of Justice. 
Lake, R., \& Driver, S. (2002). The role of algae in causing coliform problems within the distribution system. Water Supply, 2(4), 105-110.

Larsdotter, K. (2006). Wastewater treatment with microalgae - A Literature Review. VATTEN, 31-38.

Li, Y., Horsman, M., Wu, N., Lan, C. Q., \& Dubois-Calero, N. (2008). Biofuels from microalgae. Biotechnology progress, 24(4), 815-820.

Li, Y., Zhou, W., Hu, B., Min, M., Chen, P., \& Ruan, R. R. (2011). Integration of algae cultivation as biodiesel production feedstock withmunicipal wastewater treatment: Strains screening and significance evaluation of environmental factors. Bioresource Technology 102, 10861-10867.

Lim, S. L., Chu, W. L., \& Phang, S. M. (2010). Use of Chlorella vulgaris for bioremediation of textile wastewater. Bioresource Technology 101, 7314-7322.

M., T., M., T., GS., J., M., S., \& M., P. (2011). Biodiesel production from genetically engineered microalgae: future of bioenergy in Iran. Renew Sust Energ Rev, 19181927.

McKinney, R. E., McGriff, E. C., Sherwood, R. J., Wahbeh, V. N., \& Newport. (1971). A Head Activated Algae. Water and Wastes Engineering 8 no.9, 50-51.

Metting, F. (1996). Biodiversity and application of microalgae. Journal of Industrial Microbiolog, 17(5-6), 477-489. 
Mitsuhashi, S., Hosaka, K., Tomonaga, E., Muramatsu, H., \& Tanishita, K. (1995). Effects of shear flow on photosynthesis in a dilute suspension of microalgae. Applied microbiology and biotechnology, 42(5), 744-749.

Mostert, E. S., \& Grobbelaar, J. U. (1987). The influence of nitrogen and phosphorus on algal growth and quality in outdoor mass algal cultures . Biomass, 219-233.

Munoz, R., \& Guieysse, B. (2006). Algal-bacterial processes for the treatment of hazardous. water research. 40, 2799-2815.

Munoz, R., Köllner, C., Guieysse, B., \& Mattiasson, B. (2004). Photosynthetically oxygenated salicylate biodegradation in a continuous stirred tank photobioreactor. Biotechnology and bioengineering, 87(6), 797-803.

Mutanda, T., Ramesh, D., Karthikeyan, S., Kumari, S., Anandraj, A., \& Bux, F. (2011). Bioprospecting for hyper-lipid producing microalgal strains for sustainable biofuel production. Bioresource Technology, 102(1), 57-70.

Noue, J. d., \& Pauw, N. d. (1988). the potential of microalgae biotechnology: a review of production and uses of microalgae. biotechnology advances, 725-770.

Noue, J. d., Laliberte, G., \& Proulx, D. (1992). Algae and waste water. Journal of Applied Phycology, 247-254.

Nurdogan, Y., \& Oswald, W. J. (1995). Enhace Nutrients Removals in High Rate Pond. water science and technology 31,12, 33-43. 
O’Farrill, N. E., Travieso, L., Benitez, F., Becares, E., Romo, S., Borja, R., et al. (2003). Population Dynamic of Algae and Bacteria in an Oxidation Channel . JOURNAL OF ENVIRONMENTAL SCIENCE AND HEALTH, 38 (4), 697-709.

Oh, H. M., Lee, S. J., Park, M. H., Kim, H. S., Kim, H. C., Yoon, J. H., et al. (2001). Harvesting of Chlorella vulgaris using a bioflocculant from Paenibacillus sp.AM49. Biotechnology Letters. 23, 1229-1234.

Olguin, E. J. (2003). Phycoremediation: key issues for cost-effective. Biotechnology Advances. 22, 81-91.

Oswald, W. (1988). Microalgae and wastewater treatment . In W. Oswald, Microalgal biotechnology (pp. 305-328). Cambridge: Cambridge University press.

Oswald, W. J. (1963). The high-rate pond in waste disposal. Dev. Ind. Microbiol, 4, 112125.

Oswald, W. J. (2003). My sixty years in applied algology. Journal of Applied phycolog, 99-106.

Oswald, W. J., \& Gotaas, H. B. (1957). Photosynthesis in sewage treatment. Trans. Am. Soc. Civ. Eng, 122, 73-105.

Pearson, H. W., Marcon, A., \& Melo, H. (2011). The removal of thermo-tolerant coliform bacteria by immbilized waste satbilization pond algae. Water Scince and Technology, 63(6), 1075-1080. 
Pienkos, P., \& Darzins, A. (2009). The promise and challenges of microalgal-derived biofuels. Biofuels, Bioproducts and Biorefining, 431-440.

Pittman, J. K., Dean, A. P., \& Olumayowa, O. (2011). The potential of sustainable algal biofuel production using wastewater resources . Bioresource Technology, 102, 1725.

Polprasert, C., Dissanayake, M., \& Thanh, N. (1983). Bacterial Die-Off Kinetics in Waste Stabilization Ponds. Water Pollution Control Federation), 55(3), 285-296.

Rawat, I., Kumar, R. R., Mutanda, T., \& Bux, F. (2011). Dual role of microalgae: Phycoremediation of domestic wastewater and biomass production for sustainable biofuels production. Applied Energy, 88, 3411-3424.

Razzak, S. A., Hossain, M. M., Lucky, R. A., \& Bassi, A. S. (2013). Integrated CO2 capture, wastewater treatment and biofuel production by microalgae culturing-A review. Renewable and Sustainable Energy Reviews, 27, 622-653.

Richmond, A. (1999). Physiological principles and modes of cultivation in mass production of photoautotrophic microalgae. Chemicals from Microalgae, 353386.

Richmond, A. (2004). Handbook of Microalgal Culture: Biotechnology and Applied Phycology. Oxford: Blackwell Sciences Ltd.

Rittmann, B. (2008). Opportunities for renewable bioenergy using. Biotechnology and Bioengineering, 203-212. 
Rubio, F. C., Sancho, M., Villasclaras, S. S., \& Pérez, A. D. (1989). Influence of pH on the kinetic and yield parameters of Scenedesmus obliquus heterotrophic growth. Process biochemistry, 133-136.

Ruiz, J., Álvarez, P., Arbib, Z., Garrido, C., J., B., \& Perales, J. (2011). Effect of Nitrogen and Phosphorus concentration on their removal kinetic in treated urban wastewater by Chlorella vulgaris. International Journal of Phytoremediation, 884-896.

Samorì, G., Samorì, C., \& Pistocchi, R. (2014). Nutrient Removal Efficiency and Physiological Responses of Desmodesmus communis at Different HRTs and Nutrient Stress Condition Using Different Sources of Urban Wastewater Effluents. Apply Biochemistry and Biotechnology, 1-16.

Sebastian, S., \& Nair, K. (1984). Total Removal of coliform and E.coli from domestic sewage by high-rate pond mass culture of Scenedesmus obliquus. Environmental Pollution, 34(3), 197-206.

Sheehan, J., Dunahay, T., Benemann, J., \& Roessler, P. (1998). A look back at the U.S. Department of Energy's Aquatic Species Program: Biodiesel from Algae. National Renewable Energy Laboratory.

Shelef, G., Sukenik, A., \& Green, M. (1984). Microalgae harvesting and processing: a literature review. United States: Technion Research and Development Foundation Ltd. 
Singh, U. B., \& Ahluwalia, A. S. (2013). Microalgae: a promising tool for carbon sequestration. Mitigation and Adaptation Strategies for Global Change, 18(1), 7395.

Su, Y., Mennerich, A., \& Urban, B. (2011). Municipal wastewater treatment and biomass accumulation with a wastewater-born and settleable algal-bacterial culture. water research, 3351-3358.

Su, Y., Mennerich, A., \& Urban, B. (2012). Synergistic cooperation between wastewaterborn algae and activated sludge for wastewater treatment: Influence of algae and sludge inoculation ratios. Bioresource Technology. 105, 67-73.

Tabatabaei, M., Tohidfar, M., Jouzani, G. S., Safarnejad, M., \& Pazouki, M. (2011). Biodiesel production from genetically engineered microalgae: future of bioenergy in Iran. Renewable and Sustainable Energy Reviews, 15(4), 1918-1927.

Tchobanoglous, G., Burton, F., \& Stensel, H. (2003). Wastewater engineering: Treatment and Reuse. New York: McGraw-Hill.

Uduman, N., Qi, Y., Danquah, M. K., Forde, G. M., \& Hoadley, A. (2010). Dewatering of microalgal cultures: a major bottleneck to algae-based fuels. Journal of renewable and sustainable Energy, 2(1), 012701 .

Valigore, J. M., Gostomski, P. A., Wareham, D. G., \& O’Sullivan, A. D. (2012). Effects of hydraulic and solids retention times on productivity and settleability of microbial (microalgal-bacterial) biomass grown on primary treated wastewater as a biofuel feedstock. Water Research, 2957-2964. 
Van Den Hende, S., Vervaeren, H., Desmet, S., \& Boon, N. (2011). Bioflocculation of microalgae and bacteria combined with flue gas to improve sewage treatment. New Biotechnology. 29, 23-31.

Vonshak, A. (1986). Laboratory techniques for the. In A. Richmond, Handbook of micro algal mass culture (pp. 117-145). Boca Raton: CRC Press.

Wang, L., Min, M., Li, Y., Chen, P., Chen, Y., Liu, Y., et al. (2010). Cultivation of Green Algae Chlorella sp. in Different Wastewaters from Municipal Wastewater Treatment Plant. Applied Biochemistry and Biotechnology, 1174-1186 .

Werner, S. (1981). Aquatic chemistry: an introduction emphasizing chemical equilibria in natural waters. NewYork: Wiley Interscience.

Wiley, P. E., Brenneman, K. J., \& Jacobson, A. E. (2009). Improved Algal Harvesting Using Suspended Air Flotation. Water Environment Research. 81, 702-708.

Woertz, I., Feffer, A., Lundquist, T., \& Nelson, Y. (2009). Algae grown on dairy and municipal wastewater for simultaneous nutrient removal and lipid production for biofuel feedstock. J.Environmentak Eng., 1115-1122.

Yun, Y. S., Lee, S. B., Park, J. M., Lee, C. I., \& Yang, J. W. (1997). Carbon dioxide fixation by algal cultivation using wastewater nutrients. Journal of Chemical Technology and Biotechnology, 69(4), 451-455. 
Appendices 


\section{Appendix-A Microalgae cultivation results}

\section{A-1 Microalgae growth}

Microalgae growth was monitored through three measurements: ABS, TS and TVS. The plotted curves for all these three measurements were following same patterns indicating high confidence in the results.

\section{Microalgae growth in term of absorbance (ABS)}

One of microalgae growth monitoring methods was done by daily measurement of the ABS for the reactor. As shown in Figure A-1, there is almost 1.5 day lag phase in the curve which can be considered short compare to 12 days incubation period. Also, the exponential phase was 8 days which is the longest within 12 days incubation period. Those two observations can indicate that microalgae strain Chlorella vulgaris can grow rabidly in BBM medium. After almost 10 days the stationary phase began and lasted for 2 days. Every 12 days a $100 \mathrm{~mL} \mathrm{~L}^{-1}$ microalgae suspension was taken from the reactor and replaced with $100 \mathrm{~mL} \mathrm{~L}^{-1} \mathrm{BBM}$ in order to maintain enough nutrients for biomass as well as to keep moderate biomass concentration to prevent biomass self-shading. The average growth rate of microalgae along the 12 days incubation period was estimated to be $0.90 \mathrm{~d}^{-}$

1 indicating the high growth of microalgae in this medium. Growth decreasing and inhibitions were not observed during 12 days incubation period and during the whole experimental period. 


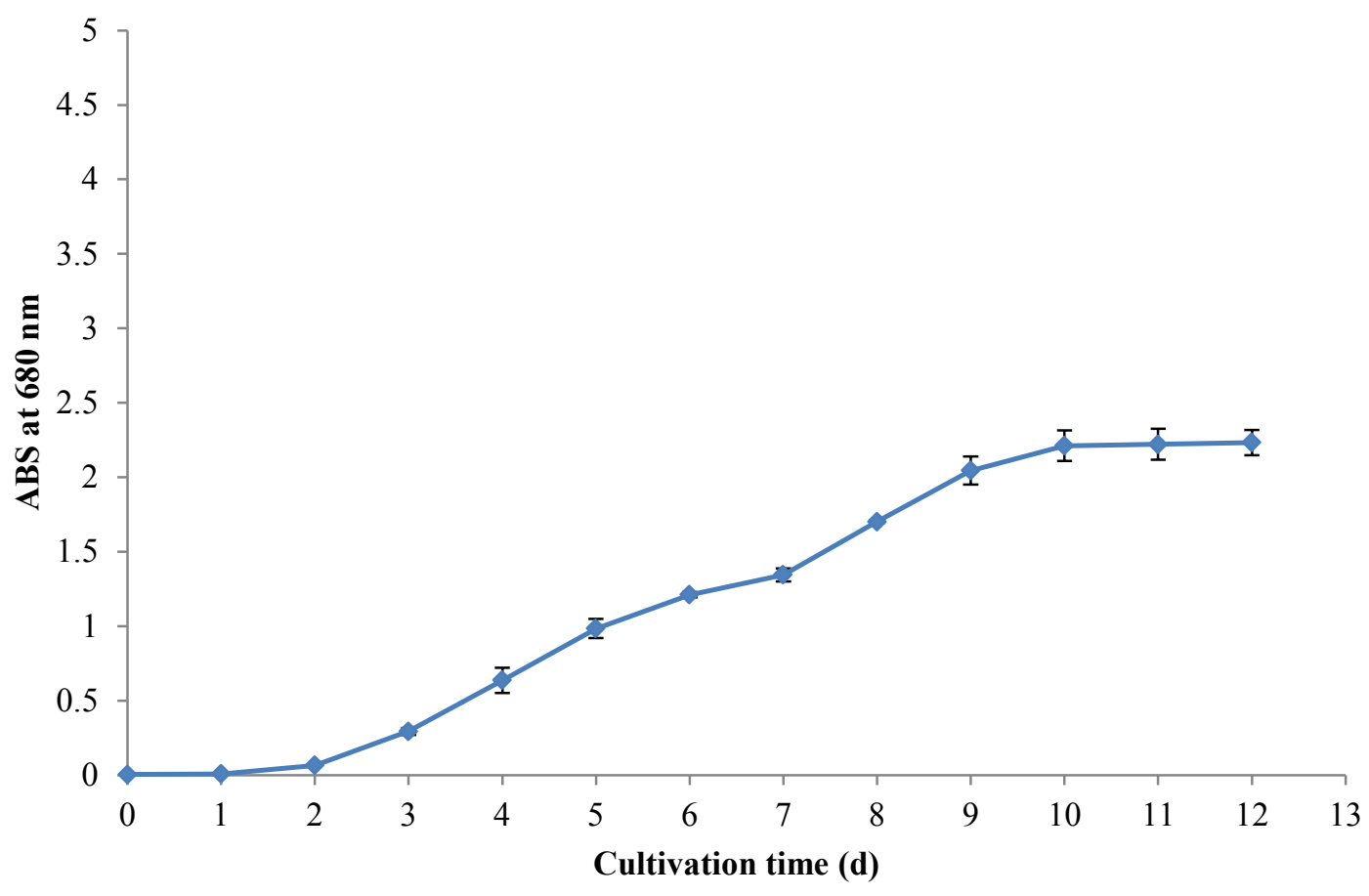

Figure A-1 Microalgae growth curve depending on absorbance

\section{Microalgae growth in term of TS and TVS}

Microalgae growth, also, was monitored through daily measurement of TS and TVS. In this case, TS consists mainly from microalgae cell, minimal concentration of other microorganisms, suspended solids and dissolved solids. TVS consist mainly of microalgae biomass.

TS and TVS concentrations increased with time. It is obvious from Figure A-2 that both TS and TVS were increasing with time and following the same pattern. The increase of TS and TVS was rapid and started from day 1 of the experiment. There was no lag or decline phase was observed. Also, Figure A-3 describes the development of the TS/TVS ratio over the cultivation period. It is noticeable that TS/TVS ratio was increasing with 
time indicting that the active portion of TS (microalgae biomass) was increasing due to the good growth.

In this study the average biomass concentration was in the range of 1000-1500 mg TS microalgae/L and the culture was not allowed to go over this range. It was mention in the literature that inhibition occurs when the microalgae biomass was in the range of 6000$7000 \mathrm{mg} / \mathrm{L}$ (Richmond, 2004) and this is due to high biomass concentration that has an effect on many factors causing growth inhibition.

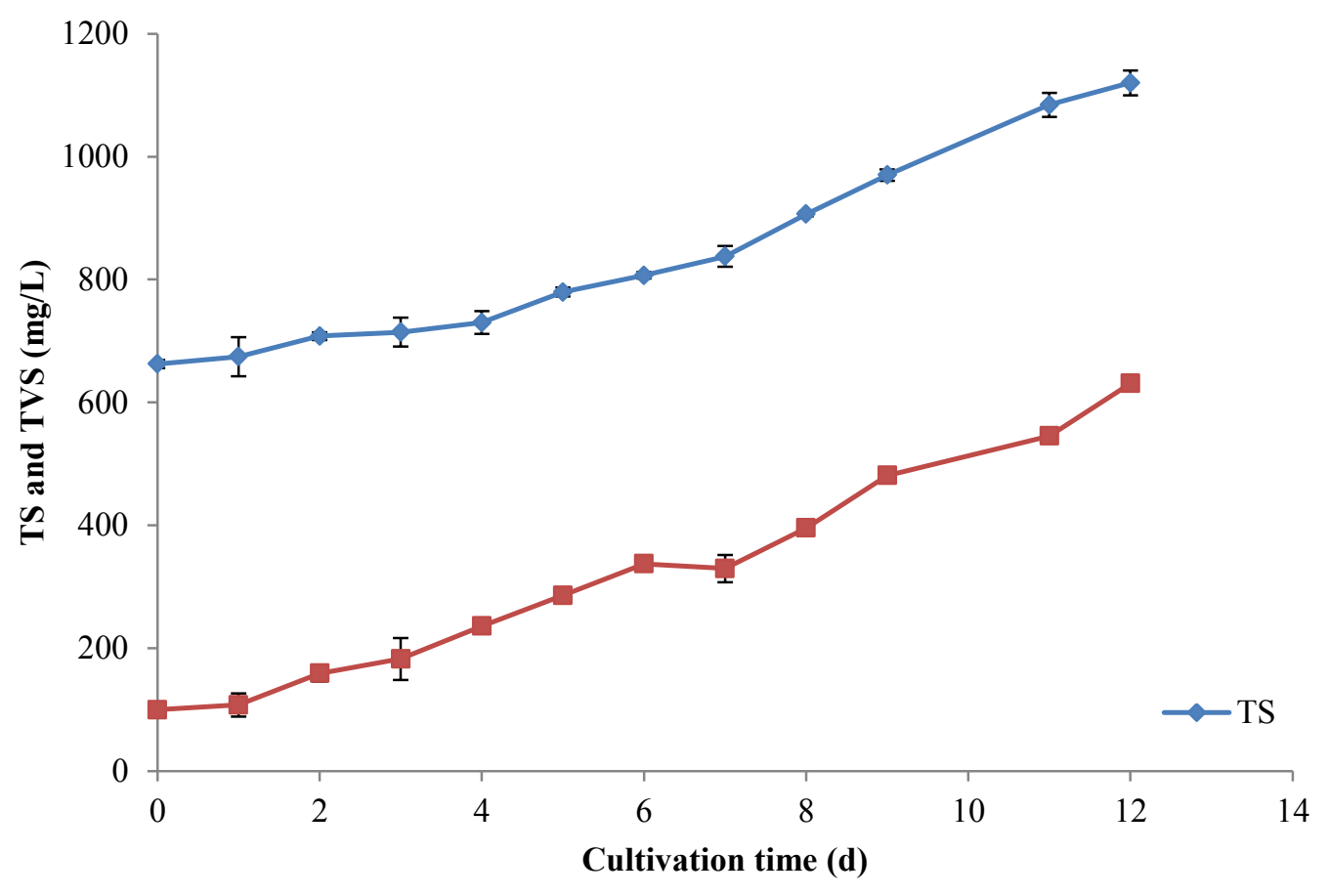

Figure A-2 Total solid and total volatile solid concentration along the cultivation time 


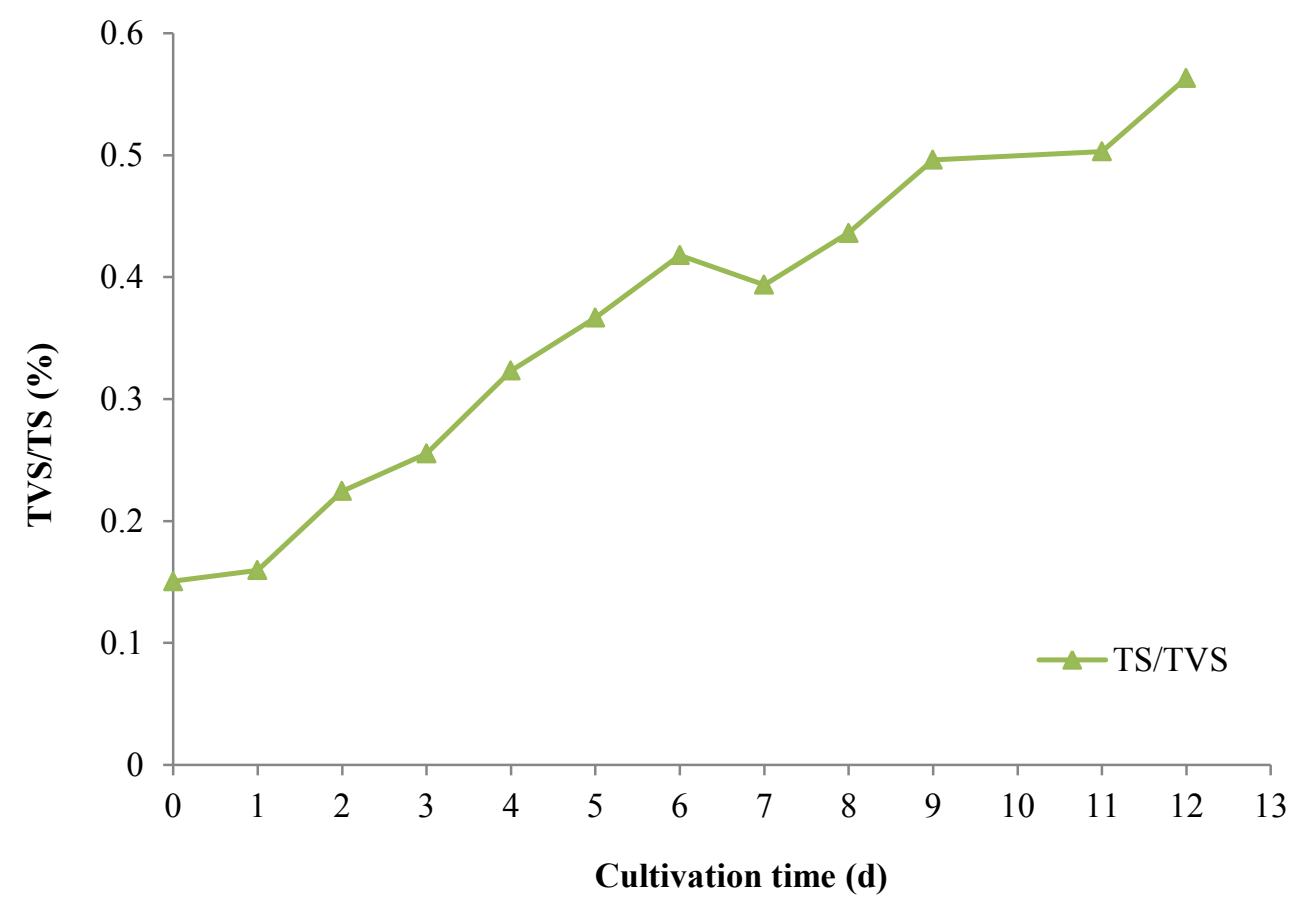

Figure A-3 TVS to TS ratio along the cultivation time

\section{A-2 Effects of microalgae on $\mathrm{pH}$ and $\mathrm{DO}$}

Cultivation of microalgae affects $\mathrm{pH}$ level and $\mathrm{DO}$ concentration in the medium. When biomass reaches a maximum, photosynthesis and the oxygenation rate reach maximum too until an optimum value. This is definitely in the presence of enough light with desired intensity. The reactor was provided with a constant aeration as a source of $\mathrm{CO}_{2}$ that is necessary for photosynthesis. The aeration rate was adjusted so that the concentration of DO in the samples was around $7 \mathrm{mg} / \mathrm{L}$. Figure A-4 shows that DO concentration was increasing with time. It increased from $8 \mathrm{mg} \mathrm{L}^{-1}$ at day 0 to $10.21 \mathrm{mg} \mathrm{L}^{-1}$ at day 12 for an average increase of $0.184 \mathrm{mg} \mathrm{L}^{-1} \mathrm{~d}^{-1}$. This increase cannot be ignored as it is valuable in term of wastewater treatment. Also, this may confirm the ability of microalgae to generate oxygen due to photosynthesis process. 


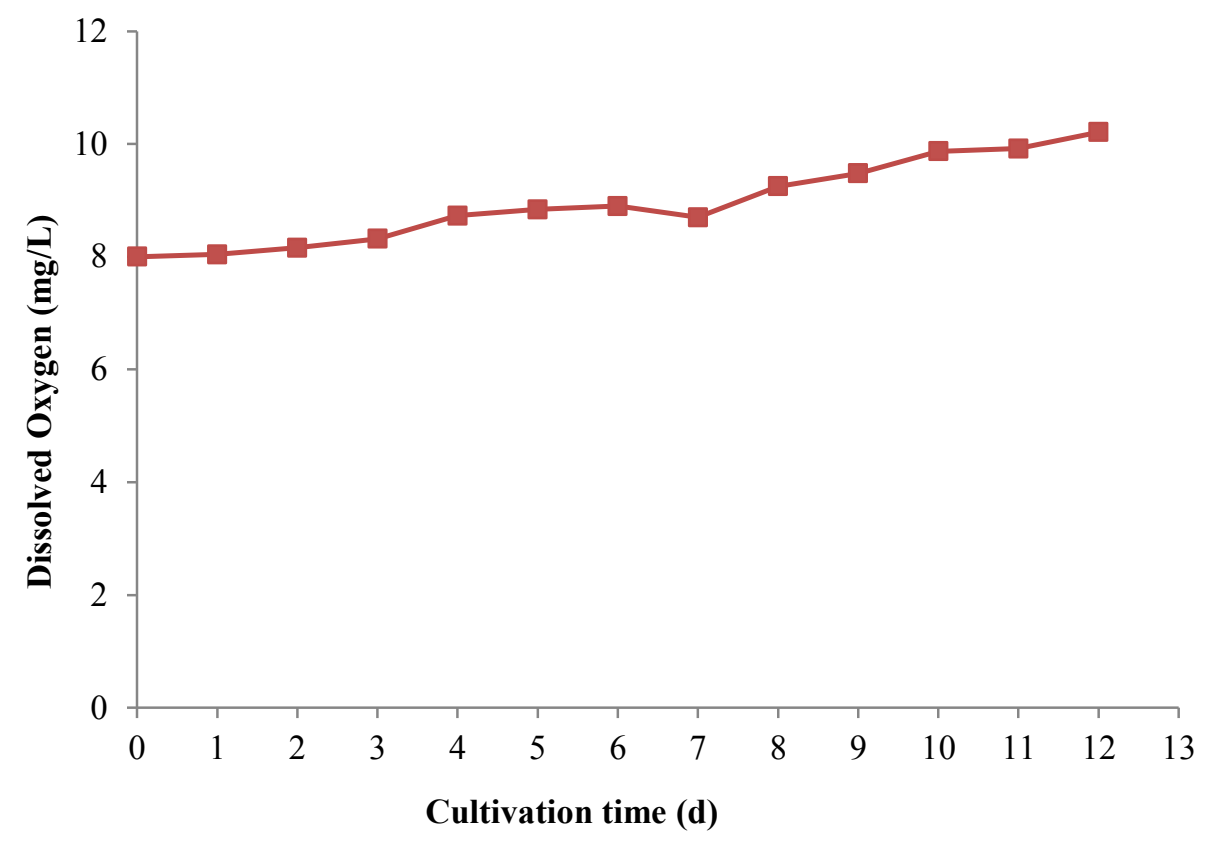

Figure A-4 dissolved oxygen development with time

Microalgae growth always associated with an increase in $\mathrm{pH}$ level of the medium. Microalgae assimilate nitrate while growing. The nitrate, then, will be reduced within the algal cell to ammonium causing an increase in $\mathrm{pH}$ level in the culture (Fallowfield et al., 1996). In this experiment, $\mathrm{pH}$ level increased from 7 at day zero to 10.1 at day 12 as shown in Figure A-5. $\mathrm{pH}$ level was not allowed to go over 11 and this was done by continueous (every 12 days) replacement of $100 \mathrm{~mL} \mathrm{~L}^{-1}$ of microalgae suspension by 100 $\mathrm{mL} \mathrm{L}^{-1} \mathrm{BBM}$ medium. $\mathrm{pH}$ of the medium may affect microalgae growth because $\mathrm{pH}$ level has direct effect on the solubility of minerals (e.g. nitrogen and phosphorus) and gases (e.g., $\mathrm{O}_{2}$ and $\mathrm{CO}_{2}$ ). 


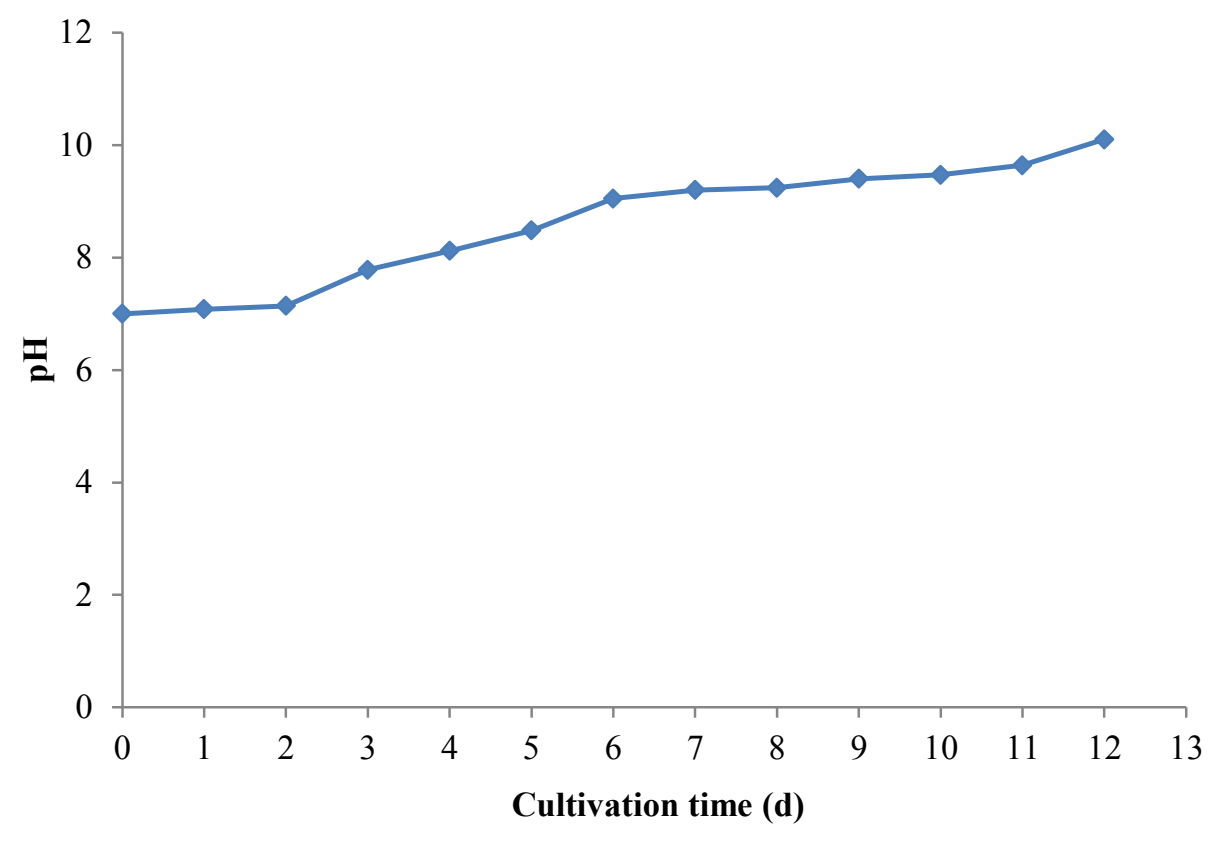

Figure A-5 Change in pH with time

\section{A-3 Microalgae harvesting}

After 12 days incubation period, microalgae suspension was centrifuged in order to be thickened to the required concentration that is needed for the main wastewater experiments. On average, each $1 \mathrm{~L}$ of microalgae suspension yielded $1100 \mathrm{mg}$ TS microalga $\mathrm{L}^{-1}$. The harvesting process was done by centrifuge the samples at $3000 \mathrm{rpm}$ because higher than this value will result in breakdown and dissociate microalgae cell. 